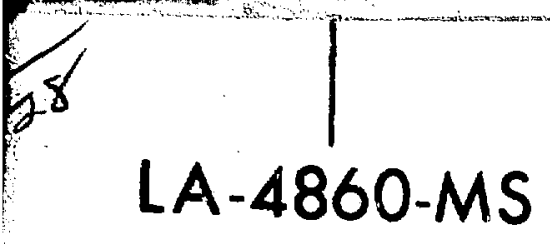

AN INFORMAL REPORT

\title{
Risk vs Benefit: Solution or Dream
}

NOTICE-

Thln. report was prepared is an sccount of work iponered by the United Stater Government. Neither the United States nor the United States Atomic Enery Commindon, nor any of their amployess, nor any of the contractors, subcontractors, of thef imployes, mikes any warminty, expres or implisd, or assumes any legal liability or reapondbility, for the eccuracy; complaterees or uinfulnesi of any information, apparatus, product or procen diaclosed, or rapresents that its use woud hot infrines peivitely owned sights. 
This report was prepared as an account of work sponsored by the United Stetes Govgrnmerit. Neither the United States nor the United States Atomic Energy Commission, nor any of their employees, nor any of their contraccors, subcontractors, or their employes, makes any warranty, express or implied, or assumes any legal liability or responsibility for the accuracy, completeness or usefulness of any information, apperatus, product or process disclosed, or represents that its use would not infringe privately owned rights.

This report, like other special-purpose documents in the LA. . MS series, has not been reviewed or verified for accuracy in the interest of prompt distribution.

Printed in the United States of America. Available from

National Technical Information Service

U. S. Department of Commerce

5285 Port Royal Road

Springficht: Virginia 22151

Price: Printed Copy 53.00; Microfiche \$0.95 
LA.4860-MS

An Informal Report

UC-41 ard UC-80

ISSUED: February 1972

los 4 alamos

scientific laboratory

of the University of Cailfornia

LOS ALAMOS, NEW MEXICO 87544

$\downarrow$

\title{
Risk vs Benefit: Solution or Dream
}

\author{
Harry J. Otway, Editor
}

A Compendium of Papers from a Symposium Sponsored by the Western Interstate Nuclear Boerd with the Cooperation of the Los Alamos Scientific Labcristory at Los Alâmos, New Mexico, November 11 and 12, 1971. 
This symposiurn entitled "Risk vs Benefit Solution or Draam?" grew out of a series of small meetings sponsored by the Western Interstate $\mathrm{Nu}$ clear Board on an isolated ranch at Breckenridge, Colorado. At these meetings, people from the nuclear industry and utilities, leading nuclear critics and representatives from the AEC laboratories were able to sit down and discuss the problems and concerns of nuclear energy in a relaxed and nnnconfrontiva atrnosphere.

The main benefit of these meetings appeared to be in the establishment of mutual respect between peoplo who held different vievs about nuclear energy, and the opportunity to discuss these views face to fact. Channels of communication were aldo opened for exchange of information which night otherwise not have happenid.
Almost all the attendees at the smaller meetings felt that an effort should be made to enlarge the meeting size in the hopes of extending the benefits of open communication to a larger number of people. Each of those who attended the larger Los Alamos meeting will have to judge the success for himself. A summary of a questionnaire giver. to those attending is presented in Appendix II.

I woild especially like to thank those attendses at the first Breckenridge meeting who formed the "Brackenridge Cabal" and without whose support and assistance the symposium would not have gotten off the ground. They are: Dean Abrahamson, Dave Engdahl, . Don Geosaman, Bob fiammon, Gary Higgins, Pete Metzger, and Harry Otway.

I also appreciate the time and effort Bill Ogle put into chairing the meeting for us.

\author{
A. T. Whatley \\ Executive Director \\ Western Inter state Nuclear Board
}


conrrams

(In Order of Presentation at Symposium)

The Quantification of Social values

H. J. Otway

Risk-Benefit Analysis Is a Dream

H. P. Wotzger

(Or in the Special case of Atomic Energy, It's a Nightmare)

Benefits and Risks fram Conventional and Nuclear

Copper Mining

Quant1tative Decision Making

G. H. Higsins

22

H. 17080

32

Same Cowents on the Public Perception of Peisonel

Chauncey starr

37

Risk and Benefit

I-1mitations of the Mind of Man: Irplications for

P. Blovic

42

Decision kaking in the Nuclear Age

Gosls of Cost-Beneflt Analysis in Blectrical Power Generation

D. B. Watson

A Case of Benerit-Risk Analysis

Jerry J. Cohen

54

56

Appendix I

59

Appendix II

61

Appendix IT 
"THE QUANTIFICATION OF SOCLAL VALUES"

\author{
by \\ Harry J. Otway \\ Universits of California \\ Los Alamos Scientific Laboratory \\ Los Alamos, New Mexico 87544 \\ Preserted At A Symposium Entitled: \\ "Risk versuk Benefit Analysis: Solution or Dream?" \\ November 11. 1971 \\ At The \\ Los Alamos Scientific Laboratory
}

In the gencral problem of determining the Bocrstal acceptability of technological application, the subject of risk- (or cost-) benefit assesament has received ever-increasing attention. THis has become, rather like the weather, something overyone talks about. In the present discussion we will confine our comments to the field of nuclear ener$8 y$, the area of greatest immediate interest to most people attending this symposium; however, the principles are applicable in the broador area of technology assessment.

Many people such as Metzger ${ }^{(1)}$, Commoner ${ }^{\{2\}}$, Gofman and Tamplin $(3)$, and other ${ }^{(4,5,6)}$, who have been sometimes lcosely grouped as "nuclear critics", have variously suggested that the riskbenefit calculus has not been properly considered in the assessment of nuclear prograns. They have, in essence, asked to see a public disclosure of and formalization of, the risk-benefit calculation. Othex $(7,8)$ have reached opposite conclusions based upon the same data. The risks and benefits of various activities have been considered, but in a largely subjective fashion. Every decision made is based upon an intuitive estimate of non-zero risks balanced against benefits that were fult to outweigh thesa risks. Subjective riak-benefit assessment has proven unworkable as seen by this controversy ourrounding the acceptance of nuclear energy programs. A number of men of appareni good will have reached opposing positiona bas.2d upon subjective appraisals of the same data. Because of this, an attempt to quantify risks and benefits appears increasingly attractive as a possible way to improve the decision making process. Now, following the U.S. Court of Appeals decision on the Calvert Cliffs nuclear power plant case ${ }^{(9)}$, the AEC nas adopted a set of guidelines for the preparation of Environmental Statements which specifically requires risk-benefit quantification:

1. . shall include a cost-benefit analysis which considers and balances. the environmental effects of the facility and the alternatives available for reducing or avoiding adver se envirunmental effects, as well as the environmental, economic, technical and other benefits of the facility. The cost-benefit analysis sinall, to the fullest extent practicable, quantify the various factors considered. To the extent that such factors cannot be quantified, they anall be discusaed in qualitative terms. "(10)

*Work done under the auspices of the U. S. Atomic Energy Commission Contract No. W-7405-ENG-36 
This essentially means that those in the nuclear field are more or less stuck with attempting to quantify the costs, or risks, and benefits in advance of the application of technology. It has been asserted that the "debate of intangible and subjective cost/benefit racios . . does not make sense" a $\mathrm{d}$ is tantamount to requiring ". . . our l'sas ned authorities symbolically to debate the number of angels that can stand on the head of a pin...

While this may seem true to those with background in physical sciences or engineering, such judgments seem premature before an attempt has been made to investigate the subject with the same vigoz that enginsering problems have been attacked.

The goal of risk-berefit quantification is not a precise computer-like formulation of decisions. Rather it is to reduce, by quantification, the number of variables involved so that better decisions can be made on a more rational basis. Further, such analyses, with a full and open disc'ssaton of the assumptions involvad, might promote informed public participation in the debate surrounding complex technical issues.

In this paper we will outline the mechanics of risk-benefit quantification to provide a common reference frame and look at some historical applications of human value judgments. Finally, we will discuss encouraging aspects of research in two areas which have received much attention as being difficult to analyze: the value of life and the quantification of subjective values.

\section{THE RISK-BENEFIT CALCULATION}

In many of the' routine activities of life there exists the possibility of sudden desth or injury. yet we continue to participate in these activities. The reason, of course, is thet the partictpant dow rives some benefit that, to him, outweighs the risk involved. A common example might be automobile trevel. More than 55, 0 p 0 people are killed annually in automobile accident:, more than two million are injured, and the automobile is a major contributor to atmoepheric pollution and resource consumption. Yet we continue to drive, because, as a society, we have subjectively and collectively decided that the benefits of personal transportation outwelgh these well-known riaks.

There are many examples of how we make, usually subconsciously, riak-benefit trade-offs in our private lives. A simple example might be that si a man living in the city who decides, partly because of the rising crime rate, that life in the city is no longer "aafe". He may then decide to move his family to the suburbs where life is "safer" and then accept an additional risk of death or injury by commuting to the city. He has subjectively decided that, in balance, the risk of being harmed due to urben crime in more than the risk of being harmed due to his additional freeway exposure. Of course, there are many other, even more subjective factors, whlch are even harder to measure. He may perconally prefer injury in an automobile accident to injury by mugging. The cleaner air in the suburbs represents a lessening in health risk as well as an aesthetic benefit. Our cultural system also would place value upon the protection of his fanily even at his own increased risk. However, the point is that a risk.obenefit evaluation, however informal, has been made. It is also important to note that this risk-benefit juig. ment has been almost entirely intuitive rather than quantitative in nature. When speaking of social group decisions as opposed to individual decisions, this intuitive approach is no longer adequate. Unless the risks and benefits are quantified, so far as possible, there are no meane for communicating individual opinions to the group.

Figure 1 shows a crude, and somewhat arbitrary, approximation of the procedures involved in making a risk-benefit quantification. The first step shown is that of enumerating the poditive (bonefite) and negitive (rieke) aspects of the proposed process, For a nuclear power plant the 
Physical Sciences

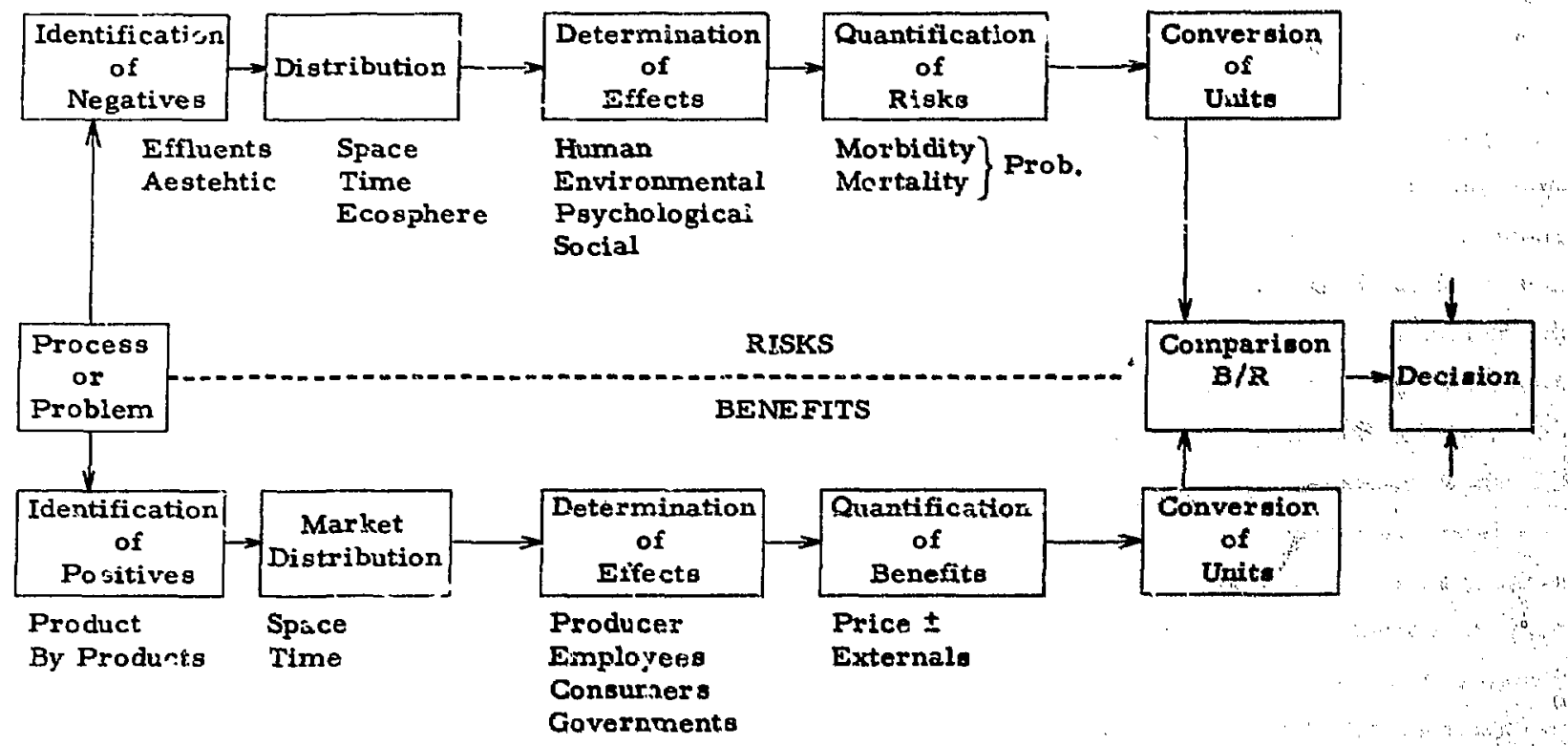

FIGURE 1: The Risk-Benofit Procesa

negative aspects might include nuclear effluents, both routine and accidental, the discharge of hot water and an aesthetic or foychic detriment. Some efforts have been made to assess the risks from routine reactor effluents ${ }^{(12)}$ and from accidental releases, is a functicn of probability, from reactors. (13) The primary beneficial aspect would be the power produced. The next consideration would be determining the distribution through the ecosphere in terms of space, time and biological species. Here we would also consider the distribution of the benefits in terms of population, space, and time.

Next, one must estimate the integrated effects of the risk and benefits. Risk examples here might be the radiation doses to humans and the effects of thermal effluents upon aquatic life. On the benefit side, one must consider the net effect of additional supplies of electricity, and the possibility: of increased soil fertility through warm water irrigation. Increased elecricicy could be positive; in the case of life-lengthening in an underdeveloped country; or perhaps negative in eupplying uninscessary labor-naving devlce to an wreacy underexercised, power-rich people. The offecte upon both the local and national economies must alio be considered here: Qliantification of negative offocts would include, for human radiologicat exponure, the morbidity-mortality probabilitie following exposure and the percoived effect of aesthotic detriment upon those affected. The upper $11 \mathrm{mit}$ of the dose-response relationship fur irradiation of humans is reatonably well known. Watson (14) has writtou on estimating the carclaogenic offects of atmospheric pollutanta through analogy with known carcinogens,

The fiast and potentialy most d iffcult te is the conversion of positive and negapto offect

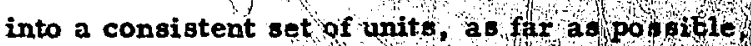
so that they may be comparadas one of ofretal

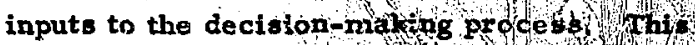

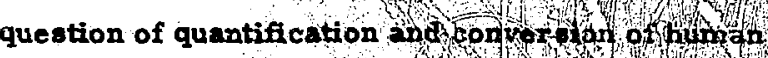

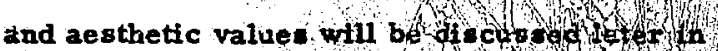
thit piper. 
Note that as the calculational process in Figure 1 moves fram left to right, there is a continunus change in the disciplines required. The design of the process is mostly a function of physical scientists while the determination of distribution and effects falls to biological scientists and cconomists. The estimation of aesthetic effects and, perhaps conversion of units, tends toward the behavioral siiences. A thorough analysis of a risk-benefit problem is truly an inter disciplinary effort and no one discipline can hope to cope with the whole process.

In addition to providing the input to decision making as shown in Figure 1 , there is a second very important function served by the analysis. There is much discussion of involving the public in cifcisions affecting the environment. The $\mathrm{Na}-$ tional Eivironmental Protective Act requirca an crivirounental analysis that is available to the pub. lice for :0 days in draft form. The idea behind this retuirement is that the "public" can then make its Injit at hearings held specifically for the purpose. This coincept is valid, however, only if the "public" can matie informed input or criticism. Mest, if not aH, members of the public, including scientists, aro jlot capable of understanding the cunsequences of, $s 7^{\prime \prime}, 1$ man-rem or $10 \mathrm{ppm}$ of $\mathrm{SO}_{2}$ in the air. The beriefit-risk quantification and conver sion of units in the last two ateps in Figure 1 should help people sinderstand the relative magnitude of the infiridua: riaks and may even bring the perceived or "fels" risks more nearly in line with the actual risks. The importance of fear of the unknown skould not be under-estimated and the jenerit3isk anilysis should help move soms of the unkuowns towari the known.

\section{AN HISTORICAL PERSPECTIVI}

Th: problems that have bsen considered most limiting in risk-benefit quantification are evaluation of humisn life and aesthetic values. However; society is constantly setting monetary values for human life, both directly and indirectly. For example, when a jury recommends a financial settlement in a loss-of-life lawsuit, they are placing a value upon human life. If, after a catastrophe causing both property damage and loss of life, one comments upon the tragedy of life loss, he has unconsciously stated that the value of those lives exceeded, to him, the value of the property. This judgment made in reverse would indicate the opposite. The concept of premium pay for people engaged in hazardous occupations provides another example. The employee effectively sets a monetisy value upon his own life in terms of the extra compenation he receives in return for accepting a certain increased statistical probability of death from his omployment.

Pexhaps one of the earlieat examples of weighing human values was for use in setting standards for social behaviox found in the Code of Hammurabi ${ }^{(15)}$, Babylonian King in the 18th Century B. C. The King's subjects were divided into three social classes. The higher classes were entitled to greater compenaation for injuries, but were also liable to heavier punishment when they themselves committed offenses. In criminal law, the question of human values was treated on the basis of equating of risks -- $i$, $e .$, the principle of "a life for a life". This extended to situations such as. the execution of the son of a man who had caused the death of another man's son. For lesser offenses, monetary compensation was prescribed. but payment was to the injured rather than to the state. Inprisonment and forced labor were not used in the criminal code.

In Anglo-Saxon and Germanic laws in the early Middle-Ages, the idea of wrong to a person, or his family, still auperseded the concept of wrong against the social group. This rosulted in a crude attempt to place monetary value upon human life and injury. These laws predate the reign of Alfred the Great $(871-899)$ and were found 
in the laws given by Henry $I$ in the 12th Century. The wer or wergild was the value set upon a man's life. This amount depended upon the social rank of the individual with a scale adjusted so that any injury (including death) to any individual had a price, increasing with his ranik. The offending party, if unable to pay the wergild to the family of the alain, was outlawed or sold into slavery. According to Norman records, the wer of a churl, then an ordinary freeman (the word has a somewhat negative connotation in modern usage) was get at four pounda, while that of a thegn, an administrative officer of a great man (such as the king) was six times greater. The unatonable offense was killing in secret, that is, by poison or witcheraft. In such cases, the murderer was delivered to the alain man's ldn for rovenge. This system gradually evolved into one where capital crime was considered an offonso against the social order. (16)

In the 17th Century, Sir William Potty eatimated the monetary value of a member of the Engliah population at "L80 . . . the value of each head of Man, Woman and Child . . "(17) His method, crude by modern economic principles, considered the total earnings of the populace and the amount of capital necessary to yield this income if invested at interest. He suggested that, from his calculation, "we may learn to compute the lose we have sustained by the plague, 'by the slaughter of men in war, .. "Farr $(18)$, in 1853, made estimates for the monetary value of life based upon the present value of future earnings. He suggested a value of 191 pounds sterling at age 15 and 246 pounds steriing at age 25:

An Engligh traveler, J, 5. Buckingham (19), told of an early effort at what is now called costbenefit analysis. He reports the aftempt of an anonymous Kentucky slaveholder, in about 1840, to compare the costs of black slaves; motivated to work only by the fesr of punishment, whth the cost of hiring free laboror :
"He said he had not only made the calcula tion, but had actually tried the oxperiment of comparing the labour of the free white man and the Negro slave; and he found the latter alway the dearer of the two. It took, for instance, 2,000 dollare to purchase a good male slave. The interest on money in Kentucky being ten per centh here was $\mathbf{2 0 0}$ dollars a year of actual cost; but to insure his life it would require at lesst five per cont more, whlch wouid make 300 dollars a : jar. Add to thit the neces aary expendes of maintenance while healthy, and medical attendance while wick; with wages of white overseers to every gang of men to see that they do their duty, atid other incidental charges, and he did not think that a slave could cost low in interest, insurance, nublistence, and watching. than 500 dollar or 100 Sterling y yorr; yet, after all, he would not do more than half the work of a white man, who covild be hired at the aame sum. without the outlay of any capital, or the Incumbirance of maintenance whillo alck, and was itlarefore, by fax the choapex labourex of the two."

Unfortunately, hivtory doen not tell un if, bojed upon this analyait, he then freod his laves.

All of these examples (a sampling of many) illuatrating early effort to asceis human values in concrete terms are today of purely hletoticul interest. However, thoy do demonstrate that man has, for a variety of reasons, had a long-tandlng interest in this problem.

\section{LIFE VALUES}

In the last section we noted that society has, both indirectly and directly, set monetary value on human life and continues to do ob todyy. This concept can be important in the use of riok-benefit principles for technology arsessment where, as mentioned earliex there is often difficulty in com paring riak and benefit in a consistent of of linits. For a very oimple risk-benefit exerciee, the risk estimate might be expressed in unit of death statifically expected, while the etimati of benefit might appear in units of monetary valus. 
This comparison of results in these dissimilar units presents a rather complex study in value judgment.

We must realize though, that 28 a society, we place a far different value upon an identifled life as opposed to a statistically expected loss of life. For example, large sums of money might be spent to find a lost child or to rescue ourvivors of a mining disaster, wipwreck, or airplane crach. We are far more casual about a atatistically expected loss of life, such as the appropriation of fund to install a traffic light at a dangerous inter aection where someone is, ultimately, sure to be killed. The same is true of many public afety measures wirere the future victims are anonymous. The concept of placing actuarial value on human life is valid only in the statistical sense.

When we consider a eituation where riske are allocated involuntarily to the public, it is necesaary that a relatively large segment of the population be affected by the proposed activity, and that the maximum risk ascumed by any population group or individual not be unduly large. This is nicessary so that the risk-benefit distribution may be viewed statistically when risks and benefits are assumed by different groups of people. In this way decisions may be made to maximize the net benefit to society viewed as a whole.

Several eatimates have been made for thr value of the statistical life, with rather good agree* ment among various sources. Jury awarda in lossof-life lawsuite fall moatly in the range $\$ 50,000$ to $\$ 500,000$ with a geometric mean of about $\$ 250,000^{(20)}$ The present value of future income for an average man (corrected for 1971 wages) is about $\$ 200,000^{(21)}$ a fact which may not be unrelated to the magnitude of the jury awardi.

Cirlson ${ }^{(22)}$ hes oummarised several cases where, directly or indirectly, human values have been aesessed. For examplo, the hazardous duty pay for a typical U.S. Air Force pllot (captain, 10 years servicel is about $\$ 2,280$ per year. For a man flying "average" aircraft with "typical" exposure, the increased mortality probabllity resulte in a statistical life value of $\$ 980,000$. For pilots flying new jet fighters, with higher risk, the corresponding value of life reducen to $\$ 135,000$. This study also reports results of a Federal Aviation Agency study to compute the value of life saving in commercial air transport accidents. Both direct and indirect costs were included with a resulting eotimate of $\$ 373,000$ as the life value per average fatality.

$$
\text { Lightowlex }{ }^{(23)} \text { has discussed the treatment }
$$
of children with complications of spina bifida (a congenital abnormality in which the opinal column is not completely closed). Inteneive medical care is requirod for those children who survive. In thie study the cont of medical, social services and future maintenance for the survivors was eatimated at 27,250 per patient. This figure was compared to the ners cearily limited future earninge of those eventually able to work and the legal value of these lives a might be determined by lawsuit in the event of accidental death. The early modical treatment of these patients was queationed in the Iight of limited funds for maintenance of Burvivors.

More epecifically, in the nuclear fleld, oeveral investigators have made monetary estimates of the biological damage cauved by exposure to Ionizing radiation or, what expenditure is justified to avoid a given radiation exposure. This approach also rather explicity infers a monetary value for human life. Cohen $(24)$ made an estimate of $\$ 2.50$ per man-rad of radiation exposure. A Swedish study $^{(25)}$, to determine the expenditure justified to reduce public radiation exposure by one man-rad, yieldea a velue of $\$ 100$ per man-rad (eince revised to $\$ 200$ por man-rad $(26)$ \%. A oimilar atudy in England (27) repulted in a figure of "a few pounds sterling per man-rad" -- about \$10 per man-rad. Loderberg ${ }^{(28)}$ made as sumptions regarding the fraction of the U. S. national health bill attributable to genetic mutation. which might be caueed by background radiation. Baved on these 
assumptions, he arrived at a value of $\$ 100$ per man-rad exposure. He made a further estimate based on attributing a highly conservative fraction of natural cancer incidence to background radiation, which resulted in an upper-limit figure of $\$ 600$ per man-rad.

The author of this paper surveyed a number of people on their recollections of catastrophic accidents. When the ratio of property damage to number of lives lost in a particular event exceeded $\$ 200,000$, all respondants remembered primarily the property damage to the exclusion of life 1088 . This seems to represent a subconscious assessment of life value at about $\$ 200,000$ per life.

The economic estumates of life value may be converted into unit.e of dollars per man-rad for comparison purposes if we conservatively assume that the biological effects of irradiation are linear with dose and that there are no threshold or dose rate effects. For this converston we have used a figure of $10^{-3}$ for the martality probabill. ty per rad of radiation exposure, zlthough use of a smaller number would probably be justified ${ }^{(29)}$. These estimates are compared in Table I. Theae numbers, either directly or indirectly, are estimates of statistical life value. The agreement among such diverse sources is intereating.

TABLE I

VALUE OF RADIATION RISK

\begin{tabular}{|c|c|c|}
\hline & & $\$ /$ Man-Rad \\
\hline Cohen & & $\$ 250$ \\
\hline Heugran and Lindell & & $\$ 200$ \\
\hline Dunster & $\therefore$ & $-\$ 10$ \\
\hline Lederberg & & $\$ 100-\$ 600$ \\
\hline Otway & & $\$ 200 *$ \\
\hline Jury Awards & & $\sim \$ 250 *$ \\
\hline Future Earnings & & $\therefore \sim \$ 200 *$ \\
\hline Hazard Pay & 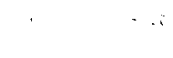 & $\$ 135-\$ 980$ \\
\hline FAA Estimate & $\because \cdot \cdots$ & $\$ 373 *$ \\
\hline
\end{tabular}

*Inferred frona life vajue estimates
To make theae comparisons, we converted the estimates of monetary value of a atatiotical life into units of radiation risk, dollars per manrad. This conversion could also be made In the opposite direction to convert Table I into unite of dollars per statiotical life. Thi contiatency is encouraging because it indicate that, in the bronder area of making rigk-beneflt anilyees, the for mulation of these difflcult value judgments is within the realm of posaibility. Whether it is acceptable is a different quention which muat be posed along with the questlon of alternatives.

\section{QUANTIFYING SUBJECTIVE VALUES}

An even more complex judgment, when one apeaks of quantlfication of riske and benefits, is that of attempting to Include ouch othereal factors as aosthetic and emotional values. Howevor, thile ia another are in which we routinoly make euch judments in an informal way. For oxample, tho auction sale of an art object. This tranaction requires that a monetary value be placed upon an article whose worth is largely aesthotic - - that is. the ales price is conuiderably more than the cost of the materials and labor involved tn creation. This is not to eay that these aesthetic ralue do not or should not exist, meroly that we often make decilions requiring the equation of monetary and aesthetic valiue.

Stary $(30)$ inveatigated the increaling acceptance (meapured oy perticipation) of varioustochnologies and found it to increase ar the escocisted riak decreased. He postulated the value of the statiatical rigk of death from diseses to be the "paychological yardetick" by which people ubjec. tively eatabilish the acceptability of other riaks. He further found the public willing to $-c c e p t$ volintary riaks about a factor of $1,000 \mathrm{higher}$ wha thet found acceptable for inyoluntary exposures.

Experimente $(31,32)$ heve fow that poople tend to be over confident in prodicting the outcomo 
of events over which they can exert nome control. This is analogous to the apparent readiness to accept higher voluntary risk: where the degree of participation can be controlled. On the other hand, evidence indicates that people tend to be underconfident when facing uncertaintive of external origin. (33) This verifies the apparent overestimation of vague environmental riaks which muat be accepted involuntarily by the public. Another study (34) looked at the probability of accidental deaths, from various causes, for the average person in the population. It was found that people intuitively eeem to be unaware of risks at a mortality riak level of $10^{-6}$ per peraon per year. A mortality risk level of $10^{-7}$ per poroon per year wae postulated ac an acceptable maximum risk for those living neareat to nuclear power plents.

A form of quantification of esentially subjective elomentn has been useful in the inveatigation of natural haxards. In a ourvey of people in 496 urban locations (35) an approxdmate log normal dietribution was postulated to deecrlbe the perception of flood haxard. That is, locatione of intermediate measured flood frequency had a higher relative percieption of flood haxard than places experiencing either more frequent or infrequent flood. ing. Another ourvey (36), also concerned with natural hasarde, adminiotered a test to aceess the risk avoidance response of people to situations representing physical, social, and natural haxarde. For the total oample, avoidance to phyalcal threat (automobile accident, attacked and robbed) was greatest with matural hasiderd in the second position above social items. Hasard avoidance was further coneilered in connection with the personal experience of the reapondante and their personality types.

Behavioral acienti ote, thoee moet familiar in dealing with subjective values, often use quantification and atatietical methode to help sort out the variables involved. For example, quantitative analyste has been useful in the clasalfication of depreseed patiente $(37,38)$ and in the formulation of a numerical scale for correlating the severity of depression and the eeriounese of suicide attempte. (39)

Another area in which subjective factors can be important ia in the percepti $n$ of phyeical illneas. In 1960, Hinkle ${ }^{(40)}$ in a survey of disabling diseased, defined the seriounese of illnese as its probability of leading to the death of the patient, otrictly a function of the entimated epidemiologic probability of death. This atudy then defined the severity of disease as the degree of disabllity incurred, that is, the extent to which a person is unable to carry out normal social function. The concept of soverity could also be quentified by wuch meacurements as the number of days miseed from work because of an epleode of llineas. Neither of these definitione includes the more oubjective componente of llinese. They aro strictly a probabliatic eatimate of death in one caee, and the meavurement of number of day disability in the other. These are useful concepte if we are interested only in a probublistic eatimate of severity or seriouenese of injury or illnees. However, oubjective values, that is, how one perceiven his ilnees, is not included in this concept.

In 1968, Wyler, (41) through survey techniques, attempted to quantify the subjective aepects of illnese from a geatalt point of view. For this eurvey, the concept of eeriounnese of illnese includid such factore a prognosic, duration, threat to life, etc.; but, more important, it also included the emotional and sesthetic factore, which influence one's perception of how serious a particular illnese is. In this study, a liet of 126 disease iteme was shown to a eample of medical out-patiente. They were then asked to rate these disesces in a quantitative manner uoing a given illnese ac a modulu* item. The quantitative ranikinge given by outpatiente to various dilesene were also compared 
to the results of the same aurvey applied to a group of physicians, whose knowledge of disease might lead them to rank disease items in a different manner than the general public. The differences in ranking between the two groups, the general public out-patients and the group of physiciens turned out to be very small. The Spearman rank order correlation coefficient between the two groups was a highly significant 0.947 . The geometric means of the quantitative rankings of these disease items was used to form the Seriousness of Illness Rating Scale (SIRS). This survey was later tried with a second group of physicians to check reproducibllity with excellent resulta; (12) and, as a further check, the crosa-cultural consistency was estimated by testing groups in Ireland and Spoin (43) again with resultant high correlation coefficiente.

In asking the sample groups to rate llinessen, peptic ulcer was given an arbitrery value of 500 points. The respondante were asked to compare the seriousness of each of the remaining lllnesices to that of peptic ulcer. That is, to rate the reletive seriousnes, uaing all their experience -direct and indirect, objective and mubjective -- in arriving at an anower. It is importint to note that this method of ranking definitely includes the emotional, aesthetic and moral prejudice associated with various diseases. A sample of some of the diseases included in the SIRS and their meen rating. is shown in Table II.

Note that the subjective impreseions of various diseases have indeed been quantifled. Syphilis, for example, which has high negative moral connothr tions in our society, but which is seldom fatal if treated promptly, was given blightly lese than helf the rating given cancer. Sexual inabllity; with an obvious emotional loacing, was rated about half as serious a heart ittack -- although nover fatal unless in conjunction with sulc!de. Such items at bad breath and dandruff may appear to be over-" valued when compared to other disense items. However, if advertiaing is any inacator, the fear
TABLE II

SOME ITEMS FROM THE SERIOUSNESS OF ILLNESS RATING SCALE

\begin{tabular}{|c|c|c|}
\hline & & MEAN SCORD \\
\hline Ieukemia & & 1080 \\
\hline Gancer & & $\therefore 1020$ \\
\hline Multiple Sclerosis & & $\therefore 875$ \\
\hline Heart Attreck & & $\therefore \quad \cdots \quad \cdots$ \\
\hline Muscular Dyetrophy & & 785 \\
\hline Stroke & & 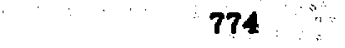 \\
\hline Blindnese & & 737 \\
\hline Chest Pain & & 609 \\
\hline Peptic Ulcer'k & & soow \\
\hline Syphilie & & 474 \\
\hline Sexual Inabllity & & 382 \\
\hline Pneumonia & & 338 \\
\hline Irrogular Hoart Beats & & 302 \\
\hline Whooping Cough & & 230 \\
\hline Meanlos & & 259 \\
\hline Acre & & 98 \\
\hline Common Cold & . & $\cdot \quad \because 62^{\prime \prime \prime}$ \\
\hline Bad Breath & & 49 \\
\hline Dandruiff & & 21 \\
\hline
\end{tabular}

Modulus Item

of bad breath and dandruff have gonerated a alzable incustry in the United Stentes. The pol nt here is that It appeare that it ie indoed poselble" to attuch come quantitative eignificance to the omotional, moral and aeothetic factor attached by people to various ailmente;

For come time a correlation betmeon prychls otrese and hysiological diwease has ben observed that change is pertons' live soem to occur in cluaters prior to the onset of phyalcal lilnese. Finkle (44) showed that it was the ingtividully parception of atrese which was correlated with iflnees. Expertence with ofver 5,000 pationt twe used to tabulicte some 43 lfo-chinge vingte which require a degree of indivdual soctat deptath of (45) 
Some of these iteme were objective changes ouch an marriage, divorce or vacation; others were far more dependent upon the indivicual's subjective interpretation of them, such a sexual difficultie or significant changes in work or eating habite.

This lict was used to form the Social Readjustment Ruting Scale (SRRS) which was adminiotered in a que otionnaire form similar to that just described for the SIRS. The perconal adaptation to marriage was used as the modulus item and arbitraxily assigned a ralue of 500 points and respozdarts were instructed to compare eash item to marriage and aseign a numerical value to the required cociel readjustment. The SRRS test wa given to groupe of whito Americans, (45) Japanese, (46) American minority groups, (47) Western Europeans, (48) and Spaniah. (43) In sach case there wa a high degree of reproducibility within cultural groups and also a high degree of crose-cultural correlation. Crose-cultural correlatione for the SRRS were not as high as that found for the SIRS. However, thin was believed due to the fict the IIIness and the perception of llinese is rather similar in different cultures, whereas the readjuatment to social change is culturally speciflc, depending more upon particular cultural values. A correlation has eince been found between life-change magnitude, ad measured by the SRRS, and the onset of serious illnese, uaing the SIRS as a measure of relative veriousnese. (49) Some iteme from the SRRS are chown in Table III. Again, the important point to be brought out here, is that elemente esentially subjective in nature have been quantified in a reproducible manner.

The examples os the quantification of aubjective valuee given here have little direct relation wip to the use of risk-benefit principlee for technology anesement of atandard aetting, but the techniques used could be applied in other flelds. The problem of the quantiflcation of ae athetic values for riakbenefit assesament does not seem an innurmountable one. The use of appropriate aurvey techniques
TABLE III

SOME ITEMS FROM THE SOCIAL READJUSTMENT RATING SCALE*

MEAN SCORE

Death of Spouse 770

Divorce 593

Marital Separation 517

Marriagew 500 w*

Death of Family Member 469

Fired from Work 378

Sex Difficulties

Pregnancy

Death of Close Friend

Trouble with In-Laws

Chenge in Residence

140

Vacation

74

Minor Law Vlolation

54

* Resulte of American Semple

* Modulus Item

could help eliminate some of the difficulty in evaluating phrases euch as "peoplo juat don't seem to like it". Indeed, even a semi-quanktative ranking of the public perception of variou alternative could be most helpful in dect aion making.

\section{CONCLUSION}

Quantitative benefit-riak andyses have been atte mpted recently but no formaliem hes evolved and been accepted. Those flrat suggeating a "cal. culua" of benpfit-riak analyais felt that quantification of auch value as human life and aesthetic values would be a diffeult and time-consuming proceas. If postible at all. A vurvey of the Htorature reveale that many of these judgmente have alxeady been made in preliminery form and techniques exist for determining others. Thus, it seeme Hikely that, with a proper inter dsciplinnry offort, performance of riak-benefit analyoes is 
within reach. As such otudies continue and more is is known about the perception of subjective valuen, subsequent efforts will become eader.

It is clear that bensfit-risk evaluations can neither be performed nar developed by "tank forces of experts" because there are no experts yet and no group of "experte" can judge the values and opinions of the people to be affected by a proposed activity. The acquileition of the required information is, however, within scientiflc capabllities if an appropriate research effort is made.

Finally, it is to be hoped that a properly performed benefit-risk analy oie, with a full discunsion of astociated assumptions, would help in communicating the elemente of complex technical procenes to the public and promote the participation of an informed public in the decision making procese.

\section{REFERENOSS}

1. H. Peter Metzger, "The Confrontation Between the Atomic Eatabliahment and the Public: Some Alternatives" Presented at the Lawrence Radiation Laboracory, Livermore, California, January 14, 1971.

2. Barry Commoneer, "Nuclear Power: Beneflts and Riske" Presented at Conference on Nuclear Power and the Pablic, University of Minnesota. October 11, 1969.

3. John W. Gofman and Arthur R, Tamplln, "Cen We Survive the Pexceful Atom?" Presented at Environmental Teach-In, Univer sity of Minnesota, Minneapolis, Minnenotn, April 22, 1970 (Gofman-Tamplin report number GT-120-70)

4. Richard E. Pogue and Dean Abrahamion, "Risk Benefit" Engage i. (13), April 1969.

5. Ralph E. Lapp, "The Nuclear Power Controver sy. Safety". The New Republic, January 23, 1971, pp. 18-21.

6. Gene Schrader, "Atomic Doubletalk", The Center Maganine. January/February 1971, pp. 29-52.

7. James T. Remey, "Nuclear Power: Benefite and Risks" Presented at Confervece on Nuclear Power and the Public. Univerdty of Menesota, October 11, 1969.
8. Glenn T. Seiaborg, "Nuclear Power and the Environment -- A Per epective" Presented at Conference on Nuclear Power, Burlington, Vormont, September 11, 1969.

9. Calvert Cliff Coordinating Committes, Inc. et al. ve United States Atomic Bnorgy Commision, ot al. U. U. Court of Appeale for the District of Columbia Circuit, No $24,1,39$ and 24,871 , July 23,1971 .

10. Faderal Register, Vol, 36, No, 175, September. 9, 1971.

11. John T. Contray, "Performance of Wpht Water Reactors," Nucloar Nowe, 14, No, 10X, October 15, 1971.

12. Stis O.W. Bargetrom, "Environimantal Consequences from the Normal Operation of an Urban Nuclear Power Plant", Presented at Health Phyalcs Soclety Md-Year Toplicul Symposium, Idabo Falls, Idabo, Novimber 1970.

13. H. J. Otway, R. K. Lohraing and M, I. Battat, "A Risk Fetimate for an Urban-sited Reactorii Nucleax Technoloc\%, 12, (1971), Pp, 173,184,

14. D. I. Tatwon, "The Rlok of Carctnoyemel from Long-Tarm Low-Dosé Expoeure to Pollution Imitted by Jospll- Fuelod Fower Plants", UCRL-50837, Octobar, 1970.

15. Encyclopaedia Britenulca, Wiltinm-Benton, Publicher, Volume 11; 1968.

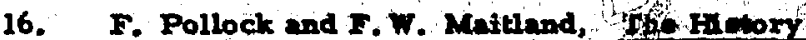

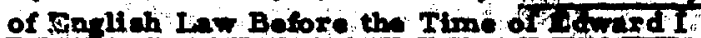
Vol. I, Cambridge Unveraty freon. I9z3.

17. Sir Wm. Potty, Political Arithmotle, Robert Glivel, London, 16\%, In Leopomie writtine of Br Wm. Potty, C.H. HWL, In, , R.X. Kelly, Bookseller, N. Y. 1963, P. 267 .

18. Wm. Farr, "The lncome ind Property Tex" J. of Stat, Soc, , XVI, 1853, p. 43,

19. D. L. Bogart, Deoromic Fintory of the Unfted Stater, Longmat, Green and Co., 1936, p. 301 .

20. J. J. Cohen, Private Communicatidin, Octobor 1970.

21. Dorothy P. Rlce and Burbura S. Coopor. "The Economic Value of Human Ite", Amoplcon Journci of Publie Hally, $57,1 \% 7$. pip. 1954-1966, 
22. Jack W. Garleon, "Valuntion of Life Saving" Ph. D. Thesit in Economice, Harvard University; 1963.

23. C.D.R. Lightowler, "Meningorryeiocele: The Price of Treatment" Britioh Medical Journal, 2. 1971, pp. 385-387.

24. J. J. Cohen, "Plowshare: New Gallenge for the Health Phy aiciat", Health Physics, 19(633) November 1970.

25. A, Hedgran and B, Lindell, "POR - A Special Way of Thirking", Health Physica, 19(1), July 1970 , p. 121.

26. Stig 0.W. Bergatrom, Private Communication, January 1971.

27. H. J. Dunster and A, S. McLean, "The Use of Risk Eatimate in Setting and Using Besic Rediation Protectlon Standarde", Fealth Phyaice. 19(1), July 1970 pS. 1:1.

28. J. Lederberg, "Squaring an Infinite Circle: Radioblology and the Value of Lifa" (DRAFT) Private Communication, June 1971,

29. J.J. Cohon, "A Suggented Guldalino for LowDose Radiation Dxposure Based on BenefitRisk Analyole" UCRL-72848, June 1971.

30. Chauncey Starr, "Benefit-Cont Relationahipe in Socio-Technical Systems" Prenented at the Symponium on Environmental Alpecte of Nuclear Power Statione, United Nationa Headquarters, Nov York, Augunt 14, 1970.

31. W. C. Howell, "An Evaluation of Subjective Probability in a Vienal Discrimination Task" Journal of Experimental Peychology, 75, 1967. Pp. $479-486$.

32. W. C. Howell, "Uncertainty from Internal and Ixternal Sources: A Clear Case of Orerconfidence" Journal of Experimental Paychology, Vol. 89, No. 2, 1971, pp, 240-243.

33. C. R, Peterson and L, R, Beach, "Man as an Intuitive Statiotician", Pychological Review, 68, 1967, PP. $29-46$.

34. Haxry J. Otwey, "The Application of Rint: Allocation to Reactor Siting and Design" Los Alamos Scientific Inboratory Report IA-4316, 1970.

35. I. Burton, R.W. Kates and G.F. White, "The Fuman Ecolory of Extreme Geophy sical Evente" Naturel Hinard Research Working Paper No. 1, Dopartment of Geography, Univeruity of Toronto, 1968.
36. S. Golant and I. Burton, "Avoldance-Reaponne to the Risk Environment" Natural Haxard Research Working Paper No. 6, Department of Geography. Univerwity of Toronto, 1969.

37. E. S. Paykil, et al, "Dimeneions of Social Adjustment in Depressed Women" Journal of Nervous and Mental Diseace, 152, 1971, pp. 158-172.

38. E. S. Paykel, "Classiffestion of Dopressed Patlente: A Clueter Analy sis Derived Grouping" Britioh Journal of Peychiatry. I18. 1971. Pp. 275-288.

39. John Birtchnell and Jose Alarcon, "Depreesion and Attompted Suicide: A Study of 91 Cases Seon in a Casualty Departmont" British Journal of Peychintry, 118, 1971, Pp. 289-296.

40. L, J. Hinklo, R. Reclmont, N. Plummer, ot al, "An Examination of the Relation Between Symptoms, Disability and Serioue Illness in Two Homogeneoue Groups of Men and Women" American Journal of Public Fealth, 50, 1960, Pp. 1327-1336.

41. A.R. Wyler, M. Manuda, T. F. Holmen, "Serlouenese of nlnese Rating Scale" Journal of Paychosomatic Revearch, 11, 1968, pp. 363-374.

42. A.R. Wylèr, M. Masuda and T. H. Holmes, "The Seriounes of Dlnese Rating Scale: Roproducibillty". Journal of Paychosomatic Research, 14. 1970, pp. 59-64.

43. Harriet H. Celdran, "The Crose-Cultural Consistency of Two Social Consensus Scales: The Sexiousnose of nlnen Rating Scale and the Social Readjuotment Ratin. Scale in Spain" Medical Thenie, University of Waehington, 1970.

4. L, I. Finkle, H. G. Wolff, "The Nature of Mar'o Adaptation to Fis Total Environment and the Relation of this to Rlnese" Archives of Internal Medicitio, 99, 1957, p. 442.

45. T. H. Holmes and R.H. Rahe, "The Social Readjustment Rating Scale" Journal of Poychosomatic Renearch 11, 1967, p. 213.

46. M. Mesuda, T. H. Holmes, "The Social Readjustment Rating Scale: \& Crop-Cultural Study of Japanese and Americans" Jowrnal of Peychosomatic Research, 11, 1967, Pp. 227-237. 
47. A. L. Komaroff, M, Masuda, T. H. Holmes, "The Social Reacjustrient Rating Scale: A Comparative Study of Negro, Mexican and White Americans" Journal of Psychosomatic Research, 12, 1958, pp. 121-128.

48. D.K. Harmon, M. Mamuda, T. H. Holmen, "The Social Readjustment Rating Scale: A Cross-Cultural Study of Western Europeans and Americans" Presented at American Paychiatric Association meeting, Bal Harbour, May, 1:69.

49. A. R. Wyler, M. Maunda, and T. H. Holmex, "Magnitude of Life Events and Serionsneas of Ilnese" Peychosomatic Medicine, 33, 1971. pp. 115-122, 
"RISK,EENEFIT ANALYSIS IS A DREAM"

(OR IN THE SPECIAL CASE OF ATOMIC ENERGY IT'S A NIGHTMARE)

by

\author{
H. Peter Metzger, \\ Colorado Committee for Environmental Information \\ 2595 Stanford Avenue \\ Boulder, Colorado 80303
}

Prosented At A Sympooium Entitled:

"Riak versua Benefit Analyals: Solution or Dream?"

At Tho

Lou Alamoe Sclenthic Laboratory

Loe Alemoe, N. M. . Novembor 11, 1971

Back in Boulder writing this apeoch, I found that I juat couldn't get a grin off my face. Thore I was ane up in my cabin in the mountains, writting - serioue talk to be dellvered to sertous people about a serious aubject, but the absurdity of it all kept on breaking through. I mean; bright guye, friende of mine, were actually trying to quantify arithruetically on the one hand, something as complex se human values, and on the other hand, trying to do so in the field of atomic enercy which is a very bad place to inveat your time and monoy thece dayn.

Now we're all here at Los Alamoa today to explore the possibilities of risk-beneflt analyole: a new approach, using rationality, to the problem. of acceptance that come up when a strange technology is presented to society.

Now, I'm going to divide my remerke into three parts. First, why the field of atomic energy is probably the dumbest place of all to begin this experiment (but I assume it started here because it's the field which most needs the sssumed benefits of rick-benefit analyais), eecondly, why, for sociological and paychological reasons, it is naive to belleve in the constructive application of riakbenefit anslysis, and leatly, what I believe will actually happen in real life.

\section{PART I.}

In the last couple of years, a new and exotic technology wae introduced into my atate of Colorado. The real truth about thia new technology, Its rioke and its benefits, were kept from the people of my state. The whole truth was a secret from them, not becuuse of nome government "eecret" claseification, but simply because of the technical complexity of the new technology; also because the only government agency reaponatible for releasing information about this new téchnology was at the ame time charged with promoting that very ame technology. At a consequence, the benefite of the technological adventure were 
exaggerated beyond all reason, while the risks were almost totally ignored.

Last month a man died in Colorado, and very probably he would not have died if it weren't for this new technology.

Now I'll bet you all think I'm going to say that he breathed some of that radioactive natural gas and that he died of cancer right there at the Rulison site, but that wasn't it. The man was an elk hunter from Texas, and he died in an avalanche near Silverton. The avalanche buried him and his companion last October 18, at a time when such avalanches were quite uncommon there. But it also happened shortly after the start of a cloud seeding project in the San Juan Mountains, an effort run by EG\&G (sound familiar?) and financed by the Bureau of Reclamation, to "mine water out of the sky" as they say, by seeding clouds with silver lodide.

Now why have I told you this atory? Imagine for a moment what would have happened if instead of an elk hunter, doad in an avalanche, it was someone else, dead of a cancer that could havo just as tenuously been blamed on atomic radlationmaybe from Project Rullson. Well you can be sure that it would have stopped that atomic ven:ure dead in its tracks. Demonstrations, lawsuits, proposed legislation outlawing atomic blasts in the state, fantastically bad press, unfavorable reports out of the Governor's Advisory Groups, ali the rest, would descend like a plague, down upon the heads of the atomic promoters. One mistake in an atomic project finishes it off. Dependirg on the mistake it could finish off all atomic projects for a fong time.

Now why is this true? Why are atomic promoters discriminated against? Why can other new technologies kill people and get away with it while atomic technology can't enjoy those same privileges?

Why there are even more similarities be. tweet we cloud seeding promoters and the AEC? Like the benefits of atomic energy, the benefits of cloud seeding have been oimilarly ornmispld to the public. You know, the typical calotilati pni are made; the total value of ach acre foot ly lititegated over the total water up thare and an astonishing figure emerge日, gigabucks of water ate up in the oky - just for the tikking. It reminds ine of those Bureau of Mines calculated, and AEC advertised, 300 trillion rubic feot of natural gas ip tight formathons all over the country, just the re for the taking. The next thing we'll see is a Bureau of Mines calculation that there is enough granite in Pikes Peak to supply the nation's tombstone needs for the neat 300 years. But there lo always a fly in the ointment. I don't know what will stand in the way of the Pikes Peak advetiture, probably some "outside agitatorg", or the eremation lobby, but the flaws in other technologies are becoming real ized already. It'o not generally known, but in at least one long attempt, cloud seeding not only cld not achieva extra rainfall, but it actually caused a net $20 \%$ reduction. That was the result of a 1969 analynis of the five-year Whitetop cloud seeding project in southern Missourl and noxthern Arkanans.

Furthormore, like atomic promoters, the cloud seeders give misleading and expaneive assurances of the safety of their technology. Not only have they provided assurances that the lonal. will not be bothered by excess snow (how that's possible is still a mystery) but their reapones to the death of the ell hunter was to assay the nearby snow for silver iodide, when they found none, they announced to the prese that their project "wain't in any way reapontible for the avalanche or heavy snows in the area" even though "the Bureau hid been seeditig cloud in the area." Iike the atomic promoter, they fidn't include in their explanation the fact that silver fodide cannot be found in detectable quantitie in the now produced by a cloud seeding operation. The way it morks is thre the silver lodide provides a micleus around which a snow cryatal formp. This snow cryatal itself 
bocoriod a rucleus for still more onow to form. In thio way ome oilver jodide cryotal catalysea the formolion of countieoo onow cryotalo. If it didn't happes chat way, you wouldn't be able to produce one itrch of sain over 20 oquare lijlometers by seeding clouclo vith only 100 gramo of silver iodice fthats as optimum rosult and a breeding factor of . trotitory. So there's dermu little oilver iodsde in aty y ven snow sample, too little to abasy for, no satiat whot. But lilse the AEC, (who ifoely and sustely actrertioed that the high levelo of radioactivicy ä the Grand Iunction sacon Bomeo were due to katisal tacifrotind radition there), the Bureat of Revinostion accured the public that they couldn's wat'.sly be at foult, deppite the fact that they dion's i. waw what tre hell they vere tallang about. So, lilse

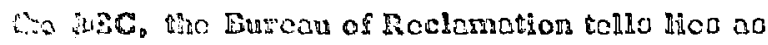
Goll. Why can tho Burcan of Reclamation get away

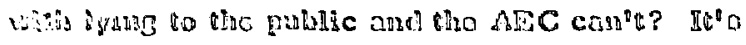
conse corno a the ABC conte cvan tell tho truth any

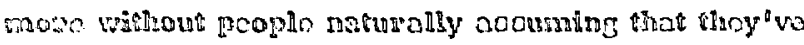

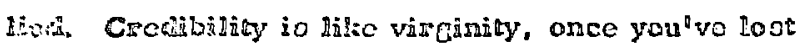

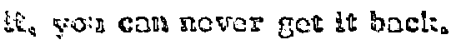

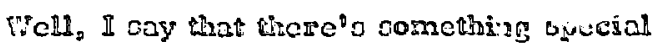
Qibats bromic encray that matroo it co harct to sell to S.e pislic. I thimi most of you here trill agree to

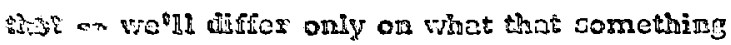

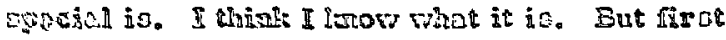
les we tell you come of the thimgo it ion't, Firgty, wtcithoris of the American atomic cotablishment ore firad o' puring the blame on the profesaionel "Noistres-upgero" as Commiovioner Remey and Tepzonertarive Folivela call us critico of tha AEC. ray even believe thet we make our living from it.

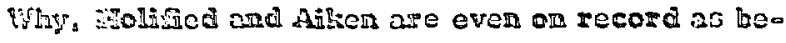

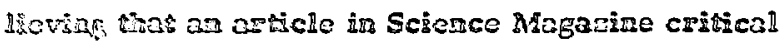
of the ABC Brings the GUPar $\$ 10,000$ fCommiaciono

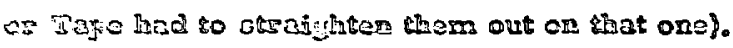
If icnt the eritics that have skewared the AnC so bat? Jow cou'd ve hove fone 60, conetderimg the ackin, tis ine AEC itsels hain't been sueh a helg?

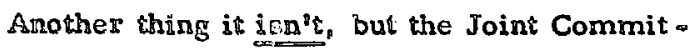
tee' $\mathrm{g}$ otaff thinlss it is, is the so-called American guilt 23 bociated with the fur ot use of atomic energy in wartime, destroying Firoshima and what's-itsname with only one bomb each. No, worse raids have happened in that war and we don't even remember them. Spealcing of what's-its-name, Nagasaki itgelf is a forgotten incident. Some books that discuss Hiroshima in detail don't even mention the Nagagnlci raid. The voluminous official history of the AEC gives the incident only one sentence, and at that, Nagasalki io mentioned as a passing reference, just something that happened on the same day that Rusbia entered the war against Japan. So war guilt as the reason is another red herring.

The real roacon io that for good cause, the American people have learned fir at to digtruet the AEC and then atomic energy in general. This is bocizuce raoot os the techsical judgments that the Atomic Innesty Commioaion hav made and told to tho public were balf-truthe, the reat were outright lie日. The Joint Committee on Atomic Energy not only backed up those lies, but added a measure of arrogance and disdain for opinion contrary to their own which completed all the ingredients necessary for what we are gecing today and about to see more of tomorrow: a wholesale rejection of nuclear energy by the public. It will be done precipitously, irrationally, and in some aspects, unjustly, but that's what is vappening and typical of their in:ensitivity and ineptraess, it is the stewards of the AEC and the Joint Committee on Atomic Energy who, issulated from the real world by each other's opinions as they are, it is they who will be the lact to trnow.

If cese you shirit my statement is extreme about the iles the AEC tells, let me diveri (in my ows defense) from the theme of this symposium, fOT $a$ Inownest, jugst to hist them. I'm finishing a boot on tire sobject, and in there, you'll find several hundred seferences of documentation, whicin Ghould convince you, in case you're not 
already. The AEC's incompetence in handing the fallout problem of the late 1950 's was glossed over by a blanket of salf - gerving lies told at the Joint Committee Hearings in 1962. Uranium purchasing policies of the AEC عant thousands of miners underground without a word of caution from the AEC, who knew at the time that 1000 European miners had already died of lung cancer under conditions that the AEC was recreating on the Colorado Pla.. teau. AEC licensed mills were permitted to so poison rivers that "biological deserts" were created in the streams and radium concentrations in the drinking water of 30,000 people far exceeded permissible limits. Hundreds of thousands of tons of uranium tailings were removed from those AEC licensed mills, under the eyes of monthly AEC inspections, so that today 5,000 home owners will receive letters this month in the city of Grand Junction, Colorado, alone, that their houseg were made dangerously radioactive because of talling used in their construction. Radioactive waste at every AEC waste depot is, according to the National Academy of Sciences, improperly stored. A final solution to the waste problem in a Lyons, Kansas, salt mine, was studied for 15 years by the AEC and the plan itself was dumfed only six months after a rush full appropriation of the whole $\$ 25 \mathrm{mil}-$ lion required was requested by the $A \mathbf{E C}$.

But here's why all of this is important: throughout every one of these blunders, the truth of the hazards involved became known only through independent and outside acienvista, over the objections of an AEC that has over the years turned into a fanatically defensive protectioniat clique of tenured bureaucrats, drawing job security and preatige from the miraculous achievement of the Manhxttan Project, here, 25 years ago, and whose best efforts today are divided between wildly inappropriate technological adventures and the justification of their past mistakes.
A year or two ago I believed in risk-beneflt analysis and baid so at a symposium here (and at Livermore and NVOO as well). I believed that if men of good will sat down together in order to get to the real business of supplying the energy needs of our nation, that a plausible form for the dialogue could be risk-benefit analysis. I've seen a lot more of the AEC and particularly the Joint Sommittee on Atomic Energy since then, and I've changed my opinion. I don't think there are enough men in either of those two buresucracies of good will and proper motivation to swing the balance the other way.

No, I wouldn't take a delicate new idea like risk-bensfit analysis and subject it in its infancy to being tarred with the same brush that being used today, and justly so, to tar and feather the AEC.

\section{PART II}

I said I'd tell you next why, for sociologled and poychological reasons, it's natve to belleve in the constructive application of riok-benefit analy sis is at this early stage in ito history. That is: what it is I think which will not work. By the extension of sctentific logic into the fteld of human sociology and paychology, it attempte to quantify and thus to reduce to arithmetic parametera, humen values, so that they may be arithmetically manipulated to facilitate their comparison, one with another. The values, thus compared, are adjusted to make a fair case, for or againet a new tenhology, Whether the risk-benefiters admit it or not, they tacitly expect that the public, impresed with the logic of the deliberations, and similarly logicelly Inclined, will accept the conoidered judgments in the riskbenefit analyals and everythiag will be jiat swell.

The values typically compered (although not alway a) are phyaical comfort and life shortening. It can be as simple as this: a dollar value is asaigned to a human life, and a number of rema 
is accepted as that amount of radiation needed to cause "one statistical death". The first figure is divided by the second and you get a dollar value for the amount of "death", a certain amount of radiation will cause. Then you apply this number: you can examine a new atomic benefit-risk producer and determine what benefit each man will receive from it in terms of kilowatts or whatever. Then you calculate his risk in rems, from which you derive his degree of "life shortening". Then, over coffee. you tell your lab mates what you've done and it's all a lot of fun.

Its the kind of game scientists like: You come up with astonishing figures (that's why scientists like it) such as: "What's all this fuss about Project Rulison anyway? Why, each man's risk hat a dollar value of only 0.1 ". It becomes obvious to all the technical types in the cafeteria that there's something to the argument after all. Besides, It's a new way of looking at things and that's something that scientists are hypnotized by. If there's one intellectual occupational harard of the scientist, It's his tendency to get carried away by a new idea - sometimes too far.

And that's what I think we're observing here: A clever, ingenious and intellectually atimulating dream. Risk-benefit analysis will fail, not because the men promoting it are not of good will, but because they have dropped a very important parameter from their calculus. That parameter will be very difficult to develop because it must account for the fact that all those people out thore aren't similarly inclined to scientific logic.

How has it worked until now? Until today the AEC PR flak would tell the public the risk argument: That the new machine doven the road will put out atomic radiation it's true, but the amount will be only a "tiny fraction" $\mathrm{cf}$ the natural background. Would you think it foolish and dismiss it if I a aid that a substantial fraction of the public might feel that zero above background is the only level they'll accept?
Representative Holifield, the most powerful single man in the American atomic establishment for 10 years or more, and the man most singlehandedly responsible for the public problems of atomic energy today, dismissed with scorn and disdain such protests. In 1969, he said of the "people in this country": "They are going to have their electricity and they are going to shut up about ecological conditions. They are all comfori seekers."

I wouldn't be surprised if many of you here today believed that same thing in 1969 too, but you don't today, otherwise you wouldin't be here. When an audience in a town in the San Juan Mountains of Colorado was being briefed on the westher modification programs there (the one that killed the hunter - maybe) a man stood up, (not exactly the radical type, either, he looked as if he atepped out of American Gothic) and said that he'd not stand for one extra flake of onow falling on his land that God didn't intend to fall there. And, later, after the meeting, he was heard to say that he would be up there at the ellver iodide generators during the winter and dynamite them right off the ridge. So much for your "natural background" argument. And I'm not sure that he doesn't have a point, either, but I told you that, because that's the situation the risk-benefiter is walking into.

But all that happened yesterday; today we have risk-benefit analysis. Let's imagine a "real" situation: An atomic enterprise comes to town and a complete and honest risk-benefit analy ais is done. Imagine a dialogue between the Riak-Benefiter and the Replesentative Average Man (RAM). Also imagine that each is equally intelligent and both are men of good will; they just don't think alike. Now before the Riok-Benefiter explains anything at all, he'a got one big obstacle to overcome, and that's what I discussed in Part I, it's the AEC:

Risk-Benefiter: Hil, sir! I'm from the Good Will Risk-Benefit Institute and we've just prepared 
this report, at our expense, (here's your own copy, sir!) which says that the new black box down the road will take atomic energy and...

RAM: (Interrupting) Now hold it right there pal. Did you say atomic energy - "cause if you did I don't want any part of it. That AEC's the biggest bunch of liars in Washington - and that's going some.

Risk-Benefiter: No, sir. I'm not from the AEC. As a matter of fact, sir, this whole enterprise is out of private industry. By law the only part the AEC plays is to oversee the safety of the project.

RAM: (ignoring Risk-Benefiter's answer) Now what's a nice guy like you doing with a bunch of liars like that anyway? No thanka, pal, I'm just not buying. I guess I'll just have to wait until it's too late - till we have brown outs and black outo and energy rationing and all before I'll come around.

But suppose, since we're supposing, that the first obstacle can be overcome, the Risk-Benefiter takes: Tack 1.

Risk-Benefiter: Well, now that we've sold you on the benefits, here's your two bits (the RiskBenefiter counts uut a nickel and two dimes and offers them to RAM). Our risk-benefit analysis says that your risk amounta to one millirem of radiation, or a "life shortening" effect of just onehalf hour; so here's your quarter.

RAM: Oh no you don't. I know how that works. Your black box up the roed will cause one statistical death since it puts out 1000 rem. It may be that all one million of us here in Cotham City will lose one half hour of life, for which we're each paid two bits, or it may mean that our new baby will die in the first year of hid life, and no one else will be affected, or since my wife and I axe both 35, and have already lived half our lives, it may mean that one or both si us will die as soon as you turn that thing on. I just can't take the chance; I reject your quarter.

Risk-Benefiter: But the odds are so great against any one person...

RAM: (Interrupting) That'a true. But it isn't the odds - it's the stakes! And there's something more. Stroke runs in my family. When we go, we go fast - a cerebrovascular accident - just like that. Radiation exposure increased your risk of cancer. That's a slow way to go - I'd rather go quickly like my father before me. You are tuking away my freedom of which way I'm going to die!

Risk-Benefiter: Oh no sir! Radiation does increase cancer, it's true, but it also decreases longevity in general. People die of all the name thing 8 , only sooner, so you can atill die of your stroke if you like - only a half hour earlier. You just age a little faeter.

RAM: Age a little faster do you? Well, my wife won't like that. I'll tell you whut - alnce you say that 1000 rem will canne "ono statisticul death" and that's worth $\$ 250,000$, why don't you go out and find the ten men whose lives are going to be ohortened by 2,500 daya each and juat give them $\$ 25,000$ each. That's not a bed deal: Seven yoare of life in trade for $\$ 25,000$ in one lump sum. I'd even buy that one.

Risk-Błnefiter: Well, olr, I'm afraid our "little exercise" (as it's been called) ien't so advanced that we can predict with accuracy just. who it will be.

RAM: Well - That's too bad becuuse if you could - then you'd have a deal. But as it ctandi, I'd Just rather pase if you don't mind.

Tack 2: Comparisons between old familine health risks and new strange health risks.

Rick-Benefiter: Well air, lot's look at it another way: Oux risk-benefit ancly is indicate that by the conventional method now uled, you are already ouffering three times the risk that the new black box will produce, and in five year af 
you taike our quarter) we'll phase out the old method so your overall risk will be cut to one third.

RAM: Look - I've been living with the old way for a long time. I feel comfortable with it. It's annoying sometimes, but it hasn't bothered me so much. Sure some daye I get a sore throat or a congested feeling in my chest, but I get over it.

Risk-Benefiter: But that's just what I'm trying to tell you sir! Don't you think that those episodes take their toll after a while?

RAM: Why - it can't be much, How bad could it be? Shorten my life by a day and a half maybe? That's not so bad.

Risk-Benefiter: Good God, wir! That' precisely what I've been trying to ay all along. $A$ day and a half is three times longer thun a half a day. You know sir ، you're very irrational.

RAM: So what else is now?

Risk-Benefiter: All right, lot's got back to those occasional sore throats and chest congestlons you've had. You know that if you were debilitated with a respiratory ailment or comething almilar. you'd be that much worse off.

RAM: Aha! Now I've got you. You see, I don't have a reapiratory aflmnnt - I don't smoke and I keep myself fit. So I'm more immune to the conventional risk than the average Average man. Now radiation is anothor story - it can hit anybody no matter bow flt they are. You can't protect yourself from It. Besldes I like the old risk - I've lived with it all my life and I ain't dead yot.

Tack 3: Dire Predictions of Economic Riaks

Rick-Benefiter: You boow ofr, if you don't thke our querter, there'll be an energy crunch, there'll be brown outs and black oute and power zatloning. Riek-benofit unaly ds doesn't concern itself with these more obvious arguments but they're there anyway.

RAM: Yos, so I hos. Woll lot me anower that one. At an average 35 year old, those probleme don't worry me too much because they're well into the future. If our countery he a severe energy criais in 30 yoars, I'll be 65 and will be past caring. My mom is 65 already and ohe doesn't care for obvious reasone. My 15 year old son wouldn't mind seeing power rationing. right now, so those arguments aimply don't imprese me.

Rick-Benefiter: But it won't be 30 years from now everywhere. Some parts of the country will be experiencing brown outs much sooner.

RAM: I've heard that too. Those are the crowded places that have all of the other problems as well. All I can say is that anyone that puts up with what they put up with must like it. Another problem won't even be noticed. You won't get any sympathy from me for those people.

Risk-Benefter: Now that's no attitude, oir! We've all got to help each other a little in this world.

RAM: Now look buddy: I know that last one didn't come out of your riek-benofit unalysis handbook there; but eince you mention it, I aay that you're askdng for behavior from me and all the other Average Men that we've nover exhibited at any time in recorded history. And epeaking of precedante, your whole pitch prenupposes a logical, scientific, measured and above all, rational responee from me and all my fellow Average Men, that Ifrewise has never exilted before in recorded history. Yon sall yourcelf a scientist - you sound more like a dreamer to me.

Risk-Benefiter: Woll olr, I'm sorry you feel that way! I'll just continue on down the block and bope that your nelghbors are more receptive than you've been. (Riek-Benefiter turns to BO).

RAM: Say, walt a minuto. I've got one more thing to add: Before you came, I mietrusted acomic energy becaues I thinik the AEC is a bunch of liars and that atomic enorgy is otrange and therefore scary. Now that you've talked to me, I'm really scared. Foll, I didn't oven krow about "Ufe shortentng" and "otatistical doath" before you came by. Now you've rellly given me something to worry about this time. I'm even more 
against new technologies now than ever before because before you only had the feeling there was danger because the AEC said there wasn't. Now you people are admitting it. No thanks - I'm not buying it.

Risk-Benefiter: You mean that I've accompliahed more harm than good by coming here?

RAM: You betcha! And that len't all, we Average Men have suspicions about you ecientists. I mean, you just can't be brought up on Frankenstein movies without aupecting that deep down all scientists have a certain Strangelovian proference for scientific experimente over the value of human life. When you came here and tell me that you calculate how many lives you're wllling to spend to promote your new technology, it just confirme our ouspicions. You know, If this whole thing wan't just make believe, we might just rus you all out of town on a rall.

\section{PART III}

If risk-benofit analyois fulls, what will happen? Well, what will heppen to what's already heppening. What riak-benofit analyste really is is non-binding erbitration: Since men all have tholr epecial interesto, nobody is Hkely to give up anything unlese ho has to. Would Calvert Clffic and the ecore of other reactore do what they've juat been forced to do if they weren't made to do so?
Can you imagine the reception any technical critic would receive if he knocked on the promoter's door and said "Please limit your technology"? Or here In Los Alamos, at a risk-benefit symposium, he presented reams of unaseailable data to support his case? It there a single precedent in human history for a promoter voluntarlly limiting his technology?

And so, after taking his case to the promoter himself, the critice take their case to the public, to the press, to the courte and to Congrese and the polemic is made public - and indirect. The promoter's charges are printed in yosterday's paper and the critic'e chargea In today's - they seldom meot in porcon.

Therefore, because it requires motives and capabilities not present in our epecies, riak-benefit analyais, as a ecientiflc diecipline, to a dream. But getting together like this has roal value. ScienHfil meetings are important not because of the formal presentatione there, but because of the informal contact one makes with hie fellowe. And I aceume in the end, that we're all followe, that is, we want to see, each in our own way, the technical probleme of our uociety solved, Corthin problems concerning the acceptance of new technologies are juct beginning to whow themselves and promoters and critice getting togother like this must turn out to be a help in solving thom. 
BENEFITS AND RISKS FROA CONVENTONAL

AND NIICLEAR COPPER MINING

by

Gary H. HIggins

\section{ABSTRACT}

The benefits and riaks, or costs, of conventional and nuclear explosion stimulated copper production methods are tabulated. Each of the risks has been evalueted in terms of 1 ts dollar value, and the ratio of the value of the copper to the sum of the values of the riake - the benefit-risk ratio - was derived. The major riske or environnental coats of conventional copper production are culfur oxides, pits, tallings, nine tumps, and miner injury. Thelr value totale between $\$ 70$ and $\$ 120$ per ton of copper produced. The major riake from nuclear explosion oolution wining of copper are ground shock and radicsctivity. Thatr value totals $\$ 5$ per ton of copper for an aseumed population distribution within 30 iles of the wine elta. For conventional copper production the benefit-riak ratio is 9 to 14 , and for nuclear production it 1. about 200 .

\section{INTRODUCTION}

This paper is an atterpt to perform a quantitative comparison of two nethods of copper production. For the reader unfaniliar with the copper Industry, brief descriptions of the mathod are included; however, because of their brevity wuch must be accepted by stipulation.

Copper Is presently recovered by mining rock contalning copper winerals and recovering and refinIng the copper from that rock in mn-made plants. The alternative proposed sethod consiets of uning the earth as the reaction vessel for recovery of a copper solution, and then refining the copper in conventiond plants. The mineral-bearing rock is firgt shattered with a nuclear exploston to allow eccess of chenicals to the copper minerals.

The paper 1s not an attempt to justify one or the other sethod. Rather, 1t 1s designed to show how two quite different technologies might be compared from an environnental point of view. A stinilar comparison of the econonice of the two sethods has been performed but is not Included in this paper.
The greateat riak from present mining methods arises from process tallings. Lesser rlsks come from refinting and smelting effluents (to both air and water), seismic or blast motion, and aesthet1c 1mpacts. The greatest rlak which may arloe from nuclear solution mining of copper to from ground shock on man-made etructures and from radiation axposure to plant workers. Lesser rlsks come from radionctivity (air and water). Thus, there can be no direct quantitative risk comparison of the differenc wining-bmelting methods because different kinds of risks arlse from each. The value judgements necessary to compare the cracking of 100 plaster walls wh the landscape degradation from a pit several cublc miles in volume are very difficult and speculative. The risks are defined in each category as quantitatively as possfble, but are based on regtonal or national sverages rather than spec1fic operations or mines. Bach alne and plant will have characteristics which will alter from the average the magntude of varlous risks at that alte. No attempt has been ande to include the variation from the averages. 
The categories of pollution, or rlsk categorles, include chemical, thermal, radloactivity, shock, noise, population, and aesthetic. "Aesthetic" Includes dust, silt, smoke, and landacape modification, and "population" pollution means crowding numbers of people into too small a space. Litcle consideration has been given to population, nolse, or thermal pollution because the environmental impact from any of the methods for coppe: recovery is small relative to the impact from other Industries and activities. In addition, the environmental impact from these categorles is relatively much smaller than from the other categorles of risk from the copper industry.

The areas of the environment upon which these categories can impact are all the parts of the biosphere. The blosphere is usually subdivided into lend surface, hydrosphere, atmosphere, and the plants and animals (Including man) which occupy these regions. The relationship between the residents and regions is the subject of ecology, although the word ecology 18 populariy confused with the word blosphere.

In this paper the word "riak" is used to describe a detrimental feature which may have hasardous effect on the blosphere, and the word "pollution" is used to describe an excessive amount of a substance in the biosphere. "Excessive" is defined by standards established in various ways. There is no case in which excessive can be defined as "presence" contrasted with "absence". The blosphere contains significant natursl radioactivity which has always been a necessary factor in mountain bullding and other orogenic processes which keep the continents from eroding away Into the seas. S1lt or dust in the atmosphero and hydrosphere ts a necessary part of the soll maintenance process. Trace elements are necessary in a variety of ways in all parts of the blosphere. For excample, a stream of pure water would be devold of all life, and if the atmosphere contained no $\mathrm{CO}_{2}$ here would be no land plants and probably no aquetic plants as well. Thus, risk involves an anticipsted detriment, the sonsequences of which are irreversible. Pollution is "too much" contrasted with "enough".

II. PRESENT COPPER MINING AND SMELTING PRACTICES The 1969 world mine production of copper was about 4.83 million matric $(100 \mathrm{~kg})$ tons, and the total refined was about 5.79 million ton/year. 1 U. S. mine production ts about 1.56 million tona, and the total copper refined in the $U$. $S$. 1s about 1.72 million tons/year. 2 The average grade of copper ore now being processed in the i.s. contains about $0.65 \%$ copper. $^{3}$ The average grade being mined worj.dFsde is a Ifttle higher. The difference betwe s copper "mined" and "rectined" Is copper recow ered secondary to some other mined value such as molybdenum.

Commonly, present copper production Involve: the following stepa: mining, willing, concentration, roasting-amelting, converting, anode casting, electrorefining, melting-casting. About: $80 x$ of all copper now produced is subjected to thla eequence of refining steps. 4 The remaling $20 x$ of world copper production is from elther the TORCO procena or by chemical leaching of dumpa or permeable underground ore deposita. The trend 18 toward increaned recovery by leaching. The TORCO process involves high temperature formation of metallic coppar with ordinary salt and charcoal as preparation for the concentration step. Thie process in uned only for a spectal class of the wore refractory ores and is not of general applicabllity. The leaching process byossses the milling, concentration, roastingswelting, and conversion steps by reavel of copper with acid, $\mathrm{B}_{2} \mathrm{Sl}_{4}$, or $\mathrm{Fe}_{2}\left(\mathrm{SO}_{4}\right)_{3}$ directly from the rock to form a dilute copper sulfate solution. The copper In solution to then reduced to cemsnt copper with Iron metal (presently the most comon practice) or concentrated by oolvent extraction processes and reduced to netal by electrowinning. Solution lenchIng followed by solvent extraction and electrowinning is becoming wore favored as a conventional recovery method because it is both economically advantageous and does not Involve $\mathrm{SO}_{2}$ production.

Mining consists of rewoval of rock-bearing copper minerals from the ground. This is corried out efther in open pits or by shafte allowing eccese to more deeply buried deposits. lost production in the U.S. 18 from open pits. The ore is unually transported from mine to mill in the form it is removed fros the mine.

sflling coustets of crushing or grinding the ore to fine particles, usually auch analier than $1 \mathrm{~mm}$ maximu particle size. 
Concentration is usually acconoliched by flotation. The finely divided ore 10 mixed tit:t water and a froth producing oll-like agent, the slurry is agitated, and air is blown Into it to produce bubbles or foan. The oineral values are concentrated In the foam which is removed from the surface and the flotation cells. Copper concent of the concentrate usually runs between $20 x$ and $50 x$.

Roasting-8melting Involves the conversion of copper winerals to crude metallic copper. At preBent, cownon practice is to heat the matertal in air $\left(\mathrm{O}_{2}\right)$ to partially convert the suifides to oxides (rossting) and then reduce the oxides and remaining sulfides to netal in an air acrean. Roasting 18 distingulshid from smelting by temperature and oxygen abundance. It is carried out below the fusion point of the concentrate, and during roasting nost of the Iron sulfides are converted to oxidea, but the copper 1s left as sulfide. Roasting is used less as a process atep with higher grade concentrates. SneltIng is accompliahed to a sortes of steps each carried out in the wolten concentrate and in the prasence of air. Firet line is edded, without addition of excese atr and Iron and ellica are removad as elag ( $\mathrm{FeSHO}_{3}$ and $\mathrm{CuSiO}_{3}$ ) laving a heavy reatdue of copper and Iron sulfides called ante. Then, after the lighter 6log is tapped off, the ante to converted to watal by infecting excese air or $\mathrm{O}_{2}$. During air Infection any remaining Iron sulfides are first converted to oxides and and to added to form FaSiO which is renoved as a surface slag. Then sone of the copper suifide is convarted to oxtde which inediately reacte with the realaing copper sulfide to form copper metal and $\mathrm{SO}_{2}$. Finally, tile Impure copper is treated with reducing gases (green wood or methane) to reduce the excese copper oxide, and anodes are cast of the product, called blfster copper.

The copper anodes averase 987 pure copper and contair as impurities gold, allver, Iron, areenic, antimony, biswath, and other antels. They are then electsorefined, during wich the anode is dissolved and plated on a cathode with electric current. The inpurtities enter the nulfate cell solution or are preciptitated as cell slines. Copper cathodes are 99.7x pure copper with Iron, Itic, sulfur, and oxygen an inpurities. This enterial is then realted and cest into ehapes used in comerce.
Several of these procedures Impact on the environment with gome potential risk. During mining, particularly in open pits, sizable charges of high explosive are detonated to fracture or broak the ore. Explnatong of 50 tone aggregate are common, and occastonally as much as 200 or more tons are detonated in large bench blasts. Ground shock from these explosions can cause etructural or archttectural damage within a radius of several ailes. The experience from these blasts and their effect on nearby structure has formed the basis of many of the standards for ground shock control. 5 Alr blast also is created during these explosions, and sone risk of window breakage ccompantes them. Except in inusual meteorological aftuations or felluze in explosion behavior, the range of window breakage is 1 ess than that of architectural danage due to ground ahock. A total of about 50,000 tons of explosive 1s detonated each year during copper aining in the U. S. There is yone enall risk anuoctated with the annufacture and traneport of thase axplosivas to the wine sites. The "pollution" from these detonatione is confined within a few wlles from the wine este.

Chemical pollintion ariees almot entirely from the erinding, arelting, and refining procesues. Each ton of copper produced creates one to five tons per year frem this source. This, in turn, is about $10 \pi$ of the total annual $\mathrm{SO}_{2}$ decharge (26 ailion tons in 1966).

Through efforte to reduce atwospheric pollutIon, eome of the $\mathrm{SO}_{2}$ is captured and converted to $\mathrm{H}_{2} \mathrm{SO}_{4}$ at the refinery aite and, as laachins processee becona sore common, the une of fire refining will dininish. Bance, $\mathrm{SO}_{2}$ production wil dieinieh. At prenent, however, no copper enelting-refining conforme to established atandarde for $\mathrm{SO}_{2}$ entecione (genes $211 \mathrm{y}$ in the order of $0.5 \mathrm{ppm}$ ). One plant in Hontane exceede etate misesion etandarda - by four to teo-fold - in apite of expenditure of tens of aillons of dollars for plant improvements and equipant to capture $\mathrm{SO}_{2}$. There saews to be, thus, Iftele prospest of confornint to the standards for several years. 6

In addition to $\mathrm{SO}_{2}$ pollueton, predomininty atwospheric, the copper industry has problews with areentc pollution in plant afr whera workere have 
abnormally high incidence of reapiratory disease. 6 Arsentc is not now genezally released in stack gases and is recovered as a byproduct with filters and precipitation.

The copper itself can, and does, become a chemical pollutant. Tallings durpe contain as much as $10 \%$ of the copper originally present in the ore. As these dumps are subjected to the effects of weather, the remaining copper minerais are elowly oxidized and become soluble in water. At wany sttes secondary dump leaching is carried on to recover this copper, but some solutions are inevitably lost. If, or when, these solutions reach streans or ground water, tiisy can produce excessive copper concentrations, Standards for water presently require copper content of such water to be 11 inted to $1.0 \mathrm{ppm}$. Thus, $1 f$ dilution were the oniy control, it would take about 20 crimion gallons of water to reduce the copper concentration to acceptable levelo from adest alzed (100 allition ton) tallinge dup during the course of ell time. Water from the flotetion tanke Is ofnilarly conteninnted with both traces of copper and wth very fine ollt. The flotation concentration procese constees about 1500 gallons of vator per ton of ore preceesed. The whole U.S. production requireg about 300 billion galions of water per year, and this water 1s wo conteninuted as to be unfic for direct disposal to etreans or other uses. In arans where it is impounded for evaporation or parcolation ell Iffe is destroyed. Thile the problei is anageable, the water thus uaed is not avallabie for wher unes.

Through inerotc and coatly efforte, the copper Induery is alouly but concluefvely solving the covencal riak probleas, but imherent to 11 these comventional processes is the ainins of ore. This creates two apperuntly unavolisble rieke; the production of inmense plles of taflinge and the permonent assthetic denge created by the pit or aines fron which the ore is rucoved and the dump on whleh the tallings ore diepoed. In the U.S. about 200 allion tow of tallings are produced ench year. wat in the forn of fine pilt or sand. This te a sivalent to a plle a mile square and bbout $200 \mathrm{ft}$ hipt: The aterial is sommint toxic to Iffe, as notex abow, and is e nource of fine dut or sediment. It is drvold of plent wetients 00 it canot custefy wagetation, and if roshed or aroded into streams, chokes most plant and animai life. It has been assumed that these tallings dumps are the necessary envirommental price of constnuing copper avallabllity. Another unavoldable price of mining Is the riak of disability or death assumed by miners. On the average, there are about 150 serious disabilities or deaths incurred by miners in the U. S. copper Industry each year. While the risk is Incurred by choice, the mining phase of the copper Industry is among the second wost hazardous group of inciustries. (Only coal mining is wore huzardous)

III. POMEATIAL NUCLEAR SOLUTION METHOD FOR COPPER RECOVERT

Since there ts netther comercial application nor full-scale field teat of this wethod, its evaluation uat be kased on calculetions and on extrapolation from laboratory and pilot plant experiments. Brlefly, the mathod convists of three staps: explosion ehattoring, oxygen leaching, and electrowinning. Ite dintinguishing and inportant feature is that no rock is removed from the ground (nining), thus avoiding the wost coetly (60 to 65\%) and undestrable stap in conventional copper recovery. In addition, it has the potential of waking new typese of copper depasts uafful as bfe because it is npplicable to the deeper, lown srade ore not presently atnable.

Since there to no afuins or ameltins connected with thle recovery wethod, fer chemical, particulate witter, or anchotic riaks are ascociated wth 1t. Slight posalble rieks could azite froi loas of acfd solutions turins punplns when contam Ination of nenr-aurface water eupplten could occur If there sere Inodequate centie precautions, and

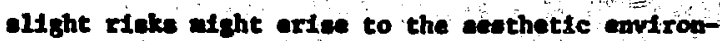
nent if good erchitecturel and houes-keppting prectices ate not followed.

Rick from radionctivity can arise durles all three plases shetering, Ieachias, and fectrowdo-

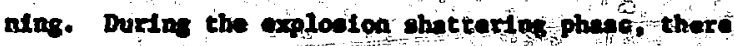
is a elight rtak of propt renting of the cxploeion produces. Buperfence obtafined durtos wapone expor-

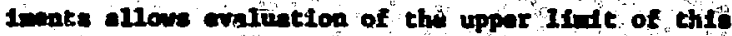
riok. There huve been 65 weapope projen taste conducted underigrovad in the low-Internediate yield range, which include the filld expected for copper ore dhattering. Jow of the teste has released 
prompt radioactivity, although three have seeped radioactive gases. Tests in this yield range are usually buried between 350 and $400 \mathrm{w}^{1 / 3}$ feet deep $(W$ - explosive yieid in kilotons, 1630 to 1860 feet for $100 \mathrm{kilotons).} \mathrm{For} \mathrm{most} \mathrm{ore} \mathrm{shattering} \mathrm{eppl1-}$ cations the $100 \mathrm{kilot}$ explosive vould be buried about $540 \mathrm{w}^{1 / 3}$ feet or deeper, and this burial would decrease the chance of both prompt venting and gas seepage wore than five-fold, as well ag reduce the amount of release in case venting should occur. Since none of the previous experiments have vented, It is not possible to calculate a venting probab111ty, but almost certainly the chance 18 less than one-in-one-thousand at the pioposed depth for copper ore shat tering. In the worgt case, radiation doses from such a one-In-one-thousand prome venting would be less than the annual exposure gufdeline atandards (0.17R) at all distances beyond 17 alles, and there would be no riak from lodine contanination in excess of standards for milk byyond 25 alles. The total dose would be $40 \mathrm{R}$ at one mile diatance, to a parson spending his whole IIfe at that location, $S \mathrm{R}$ at five ailes, $0.7 \mathrm{R}$ at $10 \mathrm{atles,}$ and $0.090 \mathrm{R}$ at 20 alles.

In a 500 allition ton ore body developed entirely by this techaique, that is, one In which there were about 100 detonations, there is lese than oneIn-ten chance that auch radinction expoaure would ever occur. As experience with nore desply burled explostons accumulates, this upper lintt should be revised, eince it is very Itbely to be too Inge by a considerable anount.

Durlas leaching, rediation risk will erise when, durins driliting, the radionctive sone is encountered near the bottor of the broken ore and when, during leuching, wo of the reclrculated gases are vented. In the firat case, besed on previous drillins experience vith seplint muclear explosion ceste and the fact that the drilling will be coaducted three wonth foliouring the detonation, the riak will be confined entirely to the operation alte and will be wil within gutdeline for rodiation workers. Dusine leschins the bleed-off geses wil potentially contiln a total of about 1500 curdes of krypton-85 which alght be releand at the rate of 5 curtee per das through a vent atack. Durins the firat two wonthe a coiparbis concentration of arroa-37 should be expected. The snees mist aleo contain as wuch as $9 \times 10^{-12}$ curies of tritium per cublc centimeter, and, if the ore body contains $1 \%$ $\mathrm{CO}_{2}$ as carbonate, about 200 curies of tritium will be released as water vapor (HTO) In nore than one billion cubic feet of gases, prinarily $\mathrm{CO}_{2}$, bled off during the leaching operation. These radiation levels are low encigh to meet present stundards for stack release, so there in but a amall riak to local Inhabitants. The worldwide Inventory of both tritIun and krypton-85 would be Increased, so there is an additional burden to the whole world population.

During electrowinning, radiation rfsks arise from the radionuclide contamination in the copperbearing actd solutions. This risk 18 borne entireIy by the operating personnel of the plant and by the enviroment imediately adjacent to or surroundIng the plant. Calculations show it is less than the radiation rifle in urantup ore processing at1ls. Riaks to the vider environsent are subject entirely to the degres of containment of the process fluids which would be recirculated into the broken rock after copper recovery. Table I showe the maximum expected level of rediactive contaniation in procese solutione during procenaing. ${ }^{9-11}$

Fate 7

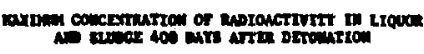

\begin{tabular}{|c|c|c|c|c|c|}
\hline Iestere & Mat/ces" & 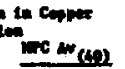 & Ieoton: & $\begin{array}{l}\text { Comonty } \\
\text { meiles }\end{array}$ & In $A v(0)$ \\
\hline $\mathrm{cos}^{131}$ & 230 & $(40)$ & 134 & 0.2 & $(\cos )$ \\
\hline 20 & 포 & (6) & $\mathbf{m}^{152}$ & 0.6 & $(2000)$ \\
\hline 123 & 37 & $(3000)$ & $c^{-60}$ & $0.0 \mathrm{ss}$ & $(n \infty \infty)$ \\
\hline $\mathrm{m}^{147}$ & $\infty$ & $(c \infty)$ & $7 \mathbf{m}^{55}$ & $n$ & $(20,000)$ \\
\hline nss & * & (cines) & $m^{22}$ & 0.03 & $(1000)$ \\
\hline 200 & 210 & (M) & $a^{114}$ & 0.95 & $(300)$ \\
\hline $\mathrm{Cs}^{140}$ & 140 & 402 & $n^{54}$ & 0.39 & $(4000)$ \\
\hline $\mathbf{n}^{123}$ & $\mathbf{s 0}$ & (20is) & $x^{6 s}$ & 0.26 & $(3000)$ \\
\hline$x^{27 m}$ & $\mathbf{0}$ & (ines) & $\mathrm{cos}^{45}$ & 3.1 . & $(300)$ \\
\hline $\mathrm{zr}^{95}$ & 30 & (any) & 15 & 23.6 & $(2000)$ \\
\hline$r^{91}$ & 130 & (n) & $e^{4}$ & 0.65 & $(1000)$ \\
\hline$=$ & 73 & (n) & 15 & e.er & $(2000)$ \\
\hline $0^{103}$ & $\omega$ & $(1+0, \infty)$ & 2 & Whe & (1)ages) \\
\hline$m^{120}$ & 7 & acisi & $9^{141}$ &.$\quad 1000$ & $(3060)$ \\
\hline
\end{tabular}

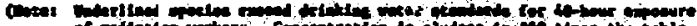

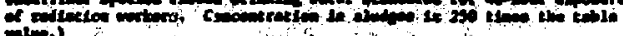
atim.) 
The fine sludges carried in the solution are expected to be about 250 times mose contaminated per unit welght than the circulating solution itself. Also shown in Table $I$ are the standards for 40 -hour exposure from drinking water to radiation workers. 12 The most severe centaminant $\left(\mathrm{Sr}^{90}\right)$ is estimated to be about 20 times the permissible level for drinking water in the plant, although the copper and acid would make the water impotable. The copper $(6 \mathrm{mg} /$ $\mathrm{cm}^{3}$ ) wili be about 6,000 times Ellowable in drinking water before copper processing, and perhaps 600 times allowable afterwards. Thus, the copper itself presents the greatest risk to plant workers, should they drink it. However, no one will drink such water, and the numbers are shown only to contrast the levels which are quite lnw.

Tritium in the form of tritlated water vapor may present an inhalation risk to plant workers in case there is poor ventilation in the process plant. With no air circulation at all, and a temperature of $21^{\circ} \mathrm{C}\left(70^{\circ} \mathrm{F}\right)$, tritium concentration in the plant could reach about 300 times the level permissible for a 40-hour week exposure, Good practice for minimizing solvent loss requires close capture hoods and ventilation, and with this equipment and reasonable plant ventilation little Inhalation exposure is anticipated.

There will be io radioactivfty in the copper product, hence no alsk to the gexeral public. Based on laboratory experimental data, ${ }^{9-13}$ the possibility of a trace ( 1 to 20 disintigrations per minute per gram of copper) of $\mathrm{Ru}^{106}$ cannot be tifminated. Th1s Is too small to be measurable without chemical separation or very sophisticated equipment, and even In photographic equipment it would sot contribute significantly to the cosmic ray background.

At the time of copper recovery, the total radioactivity (except tritium) in the rubble column is about elght times the natural radioactivity $\left(\mathrm{K}^{40}\right.$, $\mathrm{u}^{238}, \mathrm{u}^{235}$, and $\mathrm{Th}^{232}$, plus daughters). The gross gamma ray esergy emitted w11 be almost the same for natural and artificial radioactivities (800 C1) at the same time.

The nuclear explojion will create risks to existing plant facilities and neighboring structures, mines, and other manmade objects from ground shock. Based on a wide variety of experience, Table it has been prepared showing examples of the maximum range
TABLE II

GROUND SHOCK EFFECTS FKOY 100-KI BURIED 2500 FT IN BARDROCK

Effect

Definite minor damage to plant factilties or residential structures

One-in-one-thousand chance of dawage to mine tunnels or shafts

Ten percent chance of damage to process plants and associated equipmenc

One-1n-one-thousand chance of architectural damage to residential structures

One-in-one-roflition chance of minor danage to bigh-rise structures and stacks

at which various $k$ inds of ground shock hazards are expected. ${ }^{13-16}$

The specific nature of each structure and sita will detirmine the exact risk, and Table II should not be used to evaluate specific hazards. At specific sites, for example, a mine tunnel cr shaft in poor repair and subfect to imntient aatural fallure would not likely survive the ground shock at two miles, even though the probability of fallure for the "avtrage tunnel" is only one-1n-a-thousand ac that range. Similar qualifications apply to each effect category. Fron Table II it can be seen that the region within 10 to 50 miles of a nuclear solitlon copper mine is subject to ground shock risk. This risk is extremely transient and represents nolong-term threat to the local environment or ecology. Structures and man-made objects are more subfect to this rlsk than natural envirormental features.

Concern has been expressed over the secondsiry effect of ground shock on water supplies. Detalled studies of several sites and hydrologic situations Indicate there are very slight risks to the hidrologic envirozment, other than transient ehanges fn the water table level (a few inches) at distances a mile or so from the detonation site. ${ }^{15}$ Nearer the explosion site larger effects can be observed, depending on the detalis of the geologic and hydrologic environment:

IV. SUMMARY OF RISKS

It must be emphasized that the nuclear solution copper recovery method is not an alternative 


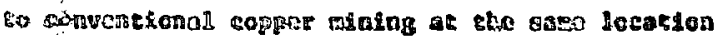
bersias te requiros a conalderably different kfed of

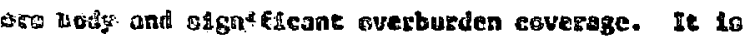

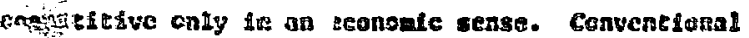

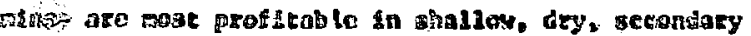
sopter depostos. while nuelear solution almes raguste

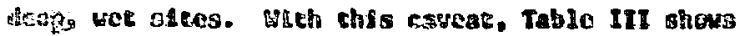

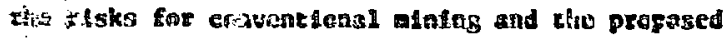

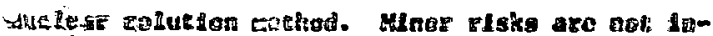
Cin

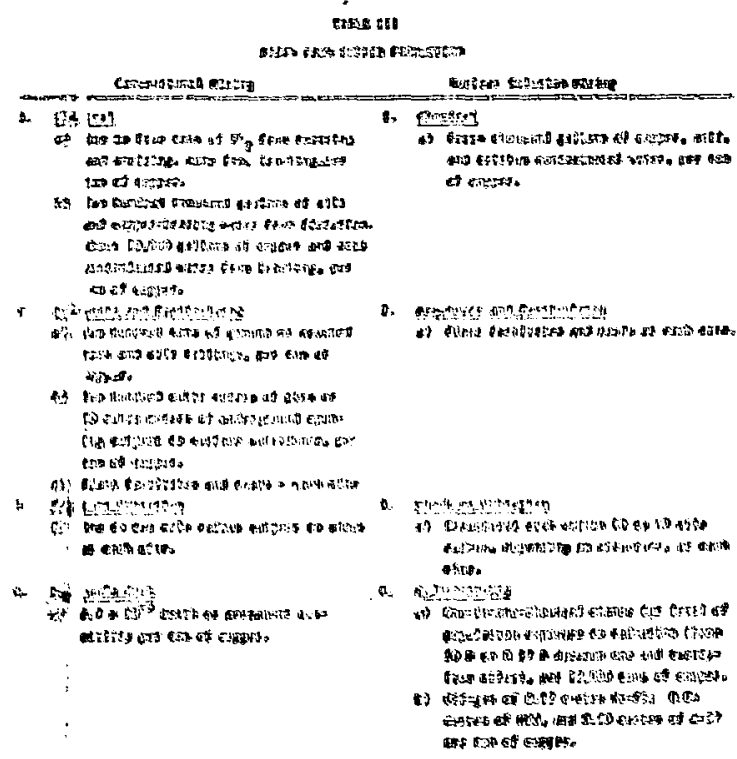

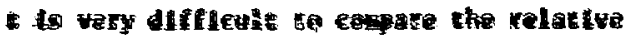

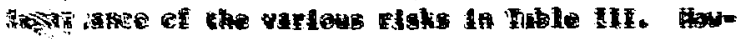

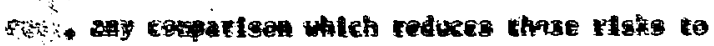

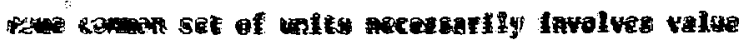

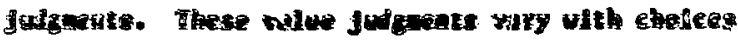

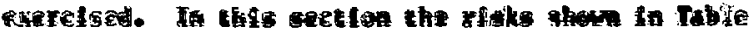

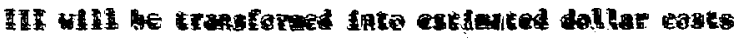

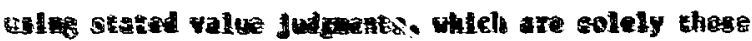
of the ayther.

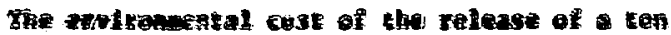

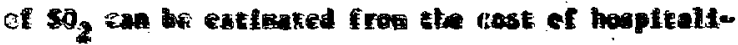

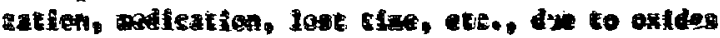

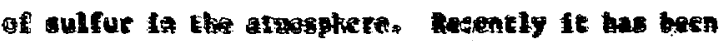

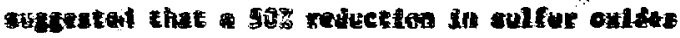
level would result in at blatos annul redustion
In health coses. ${ }^{17}$ Thlo cotinace, bascd on statscleal carselation sterdics, appears to be sozcwhat gercreus by perhaps as Euch as tuo- to five-fold. Mrewer, atoosploric pollution eouses other dotriconts besfdes pear heslth. For exasple, irritacion and genor:- Inconvontense cause conmuntey loss. A value of $\$ 1$ biliton 18 theretoro chosen for this csthate ofth the understanding chat it Ineludes both che direct healtio ceste and the cest of a less destreble envirenecte. In 1966, 23 million cons of onter of sulfur wre roleaged co the atwosphers in the linited states. 18 Frew these two nupbers, che cavirontental sas of a ton of eavironnental $\mathrm{SO}_{2} \mathrm{Ha}$ scen to be about \$43. It addicion to thin general thole atmepher gose, there wil be operfie risk as eseh ste. depenting en population and land use Eistributen.

The envitrorimental cesc of polluted vater is very ditfleule to asedgs. It the polduted wath

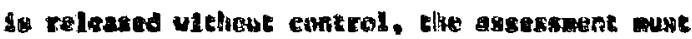
Intude inpace on the whoke echlogte chain. Arsuefag the contzol of sult water, the cest Io the towporavy loss of the water for ather uses. The valus of water dupends on the use to uhleh gt lo put. For

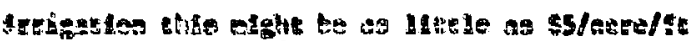

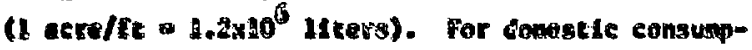

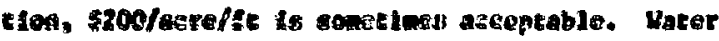
uxd in ceacantrators and pxoceses in eqnvational

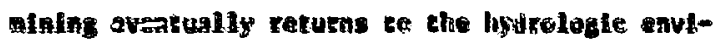
romint chrough evaporation or percolates alwhy inte ratud uatez. In the ease of nuelear soluMon alning. It is agsumd that deap ground water

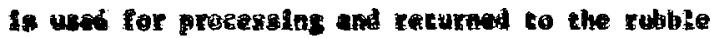
coltma. It is augstomble chat this vater vould

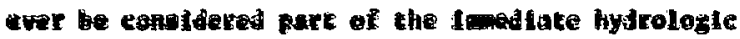
htrenterg. Fur distane future ure, one hundred of agre ysary hasee, it 18 as avallable for use as be-

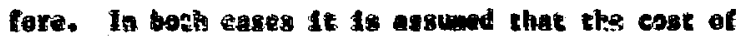
vates contentustion is $\$ 1$ acre/te. Thus, the cost of proeras wate: for convatienal fletecten-rongt-

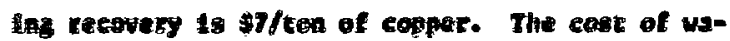
ter for boventenal laschtng and for mulear colutea staing of capper 15 about $\$ .70 /$ con of copper. seturlly, beceuse of beter control, the nuelear salteflom nothed axy be nenrer so.conften; hovevar, the higher auber vill be cyat.

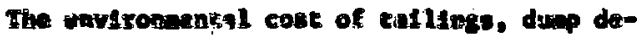
peosts, and open pits afises frow permantent sears 
to the aesthecic endrowent, eources of streas pollution, and sources of particulate pollution of the a1r. By thetr nature, they can be perranent or nealy parmanent in the ceev sence that the expond1ture ot a jeplatable rasource is a pezannent 1008. One whod for asseselos thetr environoment cost is to compute the cost of resovint them. Thus, the cost of en open pit is the cont of fillins It. Assuling the anterial can be repluced at a cont of $\$ 0.50$ per cuble meter (or $\$ 0.25$ per ton), the enviconnentel cost of the tallinge and dups would range Ino $\$ 25$ to $\$ 100$ per con of copper, depeading on the grede of ore, the ore to overburden ratio, the afnIng method, ete. If the plt or dusp te not renoved, Ite continutas ipact on the curlrowent ean be ealculeted as a diceounted future cost. Aesuning an avrage present value of these features as $\$ 50 /$ ton of copper. that the pit is Ifft unfsiled for $100 \mathrm{gre}$.

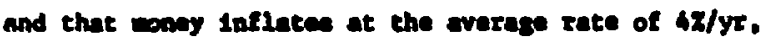
the pit cost would be somewhat over $85,000 /$ ton of copint hanerer, in Table IV we who the cost as ssi/ten of coper.

mes w

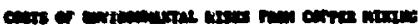

1. Sumar

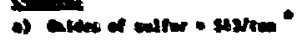

$\$$ unos rickules o then rention - 0.1hen

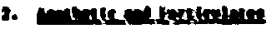

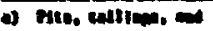

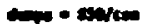

2. Diturisute colsowes

- mation

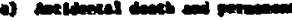

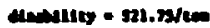

Trac o on to guspac mintolat $-12,-0.7$
2. Astol

4 - $10.1 / 0$

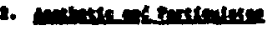
mistigte

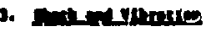

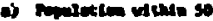

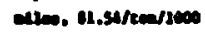
nenite.

6. menaturin

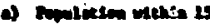

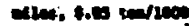
nivis.

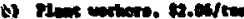

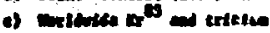
contaro

Finc a * * ind com-atse - an

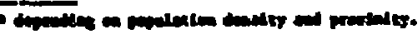

Thore are essentially no riskb from ground shock and vibration in conventional mining. Suah swall conts as are Incurred are absorbed as direct Internal costs. In the case of nuclear solution. sining, while the cost will probably be direct and retebureed, it hes a greater nulance value, afnce It extende to greeter distances. At any fivon nuclear solution alning site, these coste wut be calculated on the basts of the actual enviromiental inventory. For purposes of general essessonitat, it is assued that there are 1,000 people resident in the aren out to a radius of 50 milee, that there are 250 structures subject to danage, and that, except for the operator's plant, there are no other highrise bulldigs or senuttive comereiel fucilities. Each architectural darege Instance is assuniad to cost $\$ 500$ to repalr. Danage to the ID-plant facil1t1es 18 assund to cost $\$ 50,000$ to repalr. On the bests of the danage frequeney curve and the if gures antioned above, the cost of off-stte setande demage will be about $\$ 11 /$ ton of copper $/ 1,000$ paople. The cost of plant danage will be about \$4/ton of copper. Low probablitty danage, 1.8., a high-rise bulldins or refinery anokesteck at a distance of $40 \mathrm{mles}(60 \mathrm{~km})$, contributes a negliflble rlok par ton of copper. In the example, if we esoume $\mathbf{\$ 2 0}$ allion for the axim oas-Ip-aviliton danige; the cost would be about 1/20 of one cent per ton of coppar. sinilerly, costa for rasidential beructures neax the outex range of architectural darige. 15 to 30 wile, would be about 12 or less an Iarge as thowe calculated above. These are the conts which w11 be internalized through selenic dange ipgirance or diract repatr. The nutance cost can be estimated as the value of the time loot by those exposed to the sround shock. Agatn, assuiting 1,000 poople within 50 ales and unfori distribution beyoud 1 atle, the loes of one dey out to 10 ulles, one hour from 10 to 20 viles, and fifteen athutes fro 30 to 50 alles, the total cost, at $\$ \$ 0 / m n-d a y$, 1s $\$ 17,000$, or $\$ 1.54 /$ ton of copper.

The environential cost of radiolictivity has been the subject of a nuber of studied Including genatic dange and dieability up to ton sencratione Is the future. Sugserted values range from $\$ 100$ to $\$ 500 /$ pereon/rad. 19,20 The raleace of rediodattivity to the atmoghere Imolves both axposure to the th endiate population and to the whold world population. 
In addition, persons engaged in operation of the plant facilities are exposed to the radiaactive solutions, drill cuttings, and so forth. Cost of radiation of the while world population has been estimated by assuming the gaseous radioactivities released to the atmosphere are ultimately diffused throughout the avallable atmosphere, that each person 1s exposed uniformly for a period of time necessary for the radioactivities to decsy, and an enviromental cost of $\$ 250 /$ man-rad. The release of 1 curie of tritium as HTO thus custs the environwent about $\$ 0.10$, and the release of 1 curle of $\mathrm{kr}^{85}$ costs about $\$ 5.26 .^{20}$ On the basis of values in Table III, the environmental cost of the release of tritiun and krypton is about $\$ 0.64 /$ ton of copper.

In the interwediate range, the calculation 18 more complex and is specific to the environmental factors essoclated with each site. For purposes of calculation it has been assumed, as in the case of the seismic damage estinates, that there are 50 people living within a radius of 15 miles, and that no person lives closer than one mile. It ia alao assumed that there w111 be an anergency procedure so that in the unlikely event there 10 a proppt release of gross radioactivity, the reaidents can be protected (that 18, by evacuation), and that this protective action will cost $\$ 50 /$ day/person for a time suffictently long that exposure will not exceed a fraction of $1 \mathrm{R} / \mathrm{man}$. In this case, the genetic cost and long-term cost to the population 18 negligible compared to the cost of protective action. Since the probability la only $10^{-3}$ per detonation, or $9 \times 10^{-8}$ per ton of copper, the enviromental cost is less than $\$ .06$ per ton of copper per 1,000 people, or \$.003 pir ton of copper in the case there are 50 people in the risk region.

Within the plant, the exposure levels can and should be kept well within the limits inposed by present guidelines. If, through bad practice or afefurtune, those workers are exposed to the maxinum guideline dose, $5 \mathrm{R} / \mathrm{Yr}$, the maximum external const can be calculated from an estinate of the number if workers exposed. The total working plant force is elghteen ${ }^{21}$ so there are potentially $80 \mathrm{man}$-rem/year exposure. At $\$ 250$ per wan-rea, this is equivalent to $\$ 2.06$ per ton of copper.

The cost of workan's risk in conventional ninlag is the probability of peranent diability. times $\$ 250,000$, a rough average of Jury awards in such cases. Th1s $18.7 \times 10^{-5} \times 2.5 \times 10^{5}=\$ 21.75$ per ton of copper.

It must be emphasized that the values in Table IV depend atrongly on the judgment and agsumptions used in deriving them. Ilowever, two other factors should also be emphasized. First, the enviromental cost of the copper Industry, whether by conventional mining or the proposed nuclear solution nethod, 18 small compared to the value of the copper to society. It must be assumed, that the value of the benefit is comparable to the market price of copper - about $\$ 1,000 / t o n$. If it were not, people wouldn't buy copper since there are substitute naterials for elmost every copper uge. The total benefit-risk ratio is shown in the last line of Table IV.

The second major conclusion one can draw from Table IV is that in the conventional mining procedure, the greatest environmental cost is from the p1ts, tallings, dumps, etc. In the nuclear solution method, the greatest risks arise alnost equally from radiation hazard to in-plant workers and selomic architectural damage to the local population.

Finally, examination of Tables III and IV together permits one to conclude that the riska from the nuclear solution mining technique are Burely no greater than from conventional copper mining, and they are probably an order of magnitude less. None of the nuclear solution wethod risks involve permanent alterations to the environment. The longest rlak accrues from the krypton-85 which has an environmental half-life of 10 years and whose genetic effects axy persist up to 10 generations of people. The unfilled open pit mine remalns almost forever unless the environmental cost 18 internalized and the pit filled and landscaped after completion o? mining.

\section{REFEREHCES}

1. Sir Ronald L. Pratn, O.B.E. "The Futuze Avallabllity of Copper Supplies," Metals and Materlals, 453ff (Hovember, 1970).

2. Lane White, "Copper," E⿱E⿸yJ, 152ff (March, 1970).

3. J. D. Lotiell, "C pper ReBources in 1970," Mining Engr., 67ff (Apr11, 1970).

4. G. Armotrong Sulth, "Primary Copper: A Review of ilethods of Production and Quallty Control," Metala and Materials, $461 f f$ (Noveaber, 1970). 
5. W. E. Duval and D. E. Fogeloon, "Review of Criteria for Estinating Danage to Residencea from Blasting Vibration," Bureau of Mines Report of Investigation-5968 (1961).

6. "Anaconda Plans Outisy of $\$ 26$ afllion co Lint: Emissions of Smelter," Wall Street Journal, 25 (March 4, 1971).

7. J. E. McKee and B. W. Wo1d, Water Qunitty CrIteria (State Water Quality Control Board, Sacramento, California), 2nd ed., Publ. 3s. (USPIS standard for teste 1 ( $1 \mathrm{ppm}$ )

8. "Nature, Volune, and Activity of Mill Wantes," in Radiological Bealth and Safety in Mining ind Mtling of Nuclear Matertale. (IAEA, Vienne, Austr (a, 1964), Vol. II, p. 101.

9. E. Teller, W. Talley, G. Higetas, and G. Johnson, The Conatructive Daes of Huclear Bxploslves, (HeGraw-1111 Book Co., Kow York, 1968), Chap. 3.

10. C. A. Blake, K. B. Brown, and D. J. Crouse, unpublished data, Oak Ridge Kational Laboratory, Oak RIdge, Tennesses, (1966).

11. J. Miskel, H. Tewes, B. Rlening, R. Leseler, G. Higgins, D. Rabb, and J. Kahn, unF-blished data and calculations. Larrence Livertaore Leboratory, Liverwore, Callfornia, (1971).

12. Maximu Parnicatble Body Bundene and Maxima Pernientbie Concentration of Redionucildes in Air and Water for Decupat lonal isposure, U. 8. Dept. of Comarce, Batlonel Dureau of standarde liandbook-69, (1959).
13. L. J. Cuuthen, Jr., "The Effecte of saterie Haves on Structuras and Othor Facilities,"

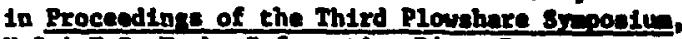
U.S.A.B.F. Tech. Information Div., Ioport TID-7695 (1964).

14. M. B. Madoisk1, "Archttecturel Danage to Dastdential structures from selanic Dieturbence," Bull. Sale. Soc. An. 59, 487 (1969).

15. "Technical Btecussions of Offolte safoty Frograns for Bnderground Huclear Detonatione," U.S.A.B.C., Revade Oparation Office, the Vepen, Levede, report wo-10 (1969).

16. S. H. Eansen and D. B. Lowerd, "Completely Containgd tuclear Explostves for inter by Caving," In Procedinge of the Thied Plowingere Slapelue, op cit.

17. L. B. Lave and B, R. Seakin, "Air Polluilon and Duman Balth," sclemes 169, 723 (1970).

18. Anon., "Mul1," Poner, P. Sm-3 (June, 1968).

19. Josuh Lederbers. Arfidavit in the Ratieton of Vermont Tenkes muclear Power Corp., Publte Marvice Bond Docket 13445 (Soptember 8, 1970 ).

20. J. J. Cohen and G. A. Higetns, Mthe Soctoncosonle Inpect of Low-lewel Irtetion nelesese to

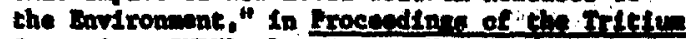

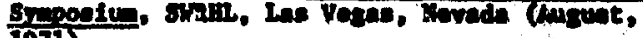
1971).

21. S. A. Gardane and G. C. T. Harwak, "SolutiomFxee Hatuluro - Copper vie Solvat Etrection," מMN 172, 110 (1971). 


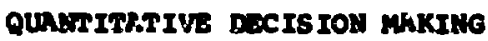

by

Mare Rose

\section{Asstrict}

Extrow uncertainty in the definition andor pvalubtion of corcain coste and bonefite mast be convidarad. positive attempte to dal with these partieular iteme qualitatively will bo more helpful than a partieular aleleading number. zthees questions are diseused in terng of the london Alrport sout-banelit analyaio.

I would like to discuse an inherwnt linitation of simple numerical indices as aide to dactaion axings the difficulty of defining and accurataly deternining the desicud quantity. Although this weting concerns nuelear powex, oxy example will be from a differant problem - afrexaft nolse. In Deceubex 1970, what was probably the nost abitlous cost/benefit analyols yot made was completed by the Roski21 Compieaton in Great Britain. 1 The comiseion labored for $2 \mathrm{~h}$ yours, opent $2 \mathrm{l}$ million dollars, and had a total atafe of about 60 , al1 to rutomend a eite for a sow London airport. This airport will be in addition to the precent wain airport, Hathrow, and the min backup aixport, Gatwicik. Their woln activities were the colculakion of the cost differences, both direct costs and sone indirect or social costa, botween difforont sites. An important part of this andyels wes the placing of mopotary values on the nuisance due to aircraft noles in the neighborinood of each projacted uirport." Thalr etudy of noise coste showad thet. since the precent population in the arese of the proposad aftes is wan11, the absolute cost and cost differ. ences due to nolse axe andl. Howevere their wethods are subject to exitieimis in addition to geperal reservations as to philosophy, on can state that investigatlons of existing nolse costs at Heathrow. the quality of noles level deterninations. and developant in tim of noise costs at any now alte, were not indertaken and would have been very valuoble. Presentation of comparison calculations for a famlilar existing eituation as wt Heathrow,

\footnotetext{
Hote that this aniysis cerried with it no suggestion that those and to oufser ahould acturliy be pald componsation. Although neer Furid' Oxly Airport group of mulelpalities have surcesefully sued for nolve coppeneation related to the actunl noloe burdan, in England weh fudgront would be explicitly ruled out by Iaw. wile in the united stetes it is a very unlikaly poosibility.
} 
would have been an ixportant wy of educating the non-profeselonal into the waning of the calculations. Hypothetical axamination of this question will laxd to basic cxiticien of the econonic wethods aployed in notse coating. The cornisaton's analysis yen thoughtful on wany detailed econanteal fuestions, wut wth regard to the qualty of prealetion of noies lovele. It wa distrubing to se. as a physienl eclentist, that no now field investigations were caxried out. $A$ noles index and contours of this index wre datermined from earliex dite and lcalised alxcraft performes.

Iat ue exandin the nuthod of costing and dicuse ite hypothetieal applieation to the noles due to prevent Enothrow operations. The basic masure of cound level is the power. $P$, the arriving cound onergy per econd (In approprinte unite and appropriately wighted in pitch). I w112 quote "h seale" wighted cound 1evis. The sound level is defined:

$$
8 \text { - } 10 \log _{10} \text { P dectbels }
$$

Typical cound lovele are.

80 as ringing alaxil elock at 1 ya.

so des ponmetic art11 or loud votele at 25 et

210 dDt suberin engine rocm.

The pake cound powe arriving from an alreraft and the nuber of alreraft por day are inportant masures of the nuibunce of afreraft nolse. An atteopt wa nnde to bring these two affects together into a otngle "notes and nuiber" lpdox (nx) in 1962. 2 acial surver established that. under conditions ther prevalent nar Hathrow. there wa a rough equivalence betwen loudnes and numer of aircraft auch that pople folt the same annoyance. leading to the annoyance Index:

$$
\text { MI }=\bar{s}-67+15 \log _{10} n
$$

Haxe $\overline{8}$ is the $160 \mathrm{l}$ aseoctated with the average of the pak sound pomes from ench asrcraft, in an, and $x$ is the muber of aircraft in a 12 hour period." only aircraft louder than 67 dB (eimilar to tho sound of normal co veration) are counted. w. wee. for examplo, that 10 aircraft dyy as loud os a pnoumietic dri11 at 25 foet would corraspond to an mit in the $10 \mathrm{w} 40^{\circ} \mathrm{s}$.

There is constderable controversy about the validity of this single indax to deserts the nuisence of aircraft notes. For exanple it does not describe dey-night differences or day to day fluctuations. If the Rosk111 study had ben extendid to beathrow, a copprieon site, it would have been essential to eubject the lexr to experimental serutiny, to reconsidar whether a single such Index is adequate. sosuning thet the asfeicultiea esccinted wth eatablishnnt of an Index are sesolved, w heve to ausest cost. is It deponde on the Indipx, comunity by commity. The camiseion's method we to hiro real estate agerits a connultents to price comparable housting at given bir and at low wi. " This apperintly gave consistont reaulte for aburbin houging in the general area of catwick airport. if w were to consider Heathrow mould

Whe wi wis offined uelng a different wighting in piteh - "porceived noirs," rather than $\mathrm{A}$ enio, delbeld, I hav wade rough adjustiont to $\mathrm{A}$ acale bocause it is faifly etandard in noise etudies.

$+2$

As a atter of general interest, I note that the comission found in auburben aroas thit madiu-priced hourling de crenced in vilua abovt $9 k$ for $35<$ bl $<$ 45 and about $17 \%$ for $45<414<55$ sxterding these result to Bathrow and including other finnelal loues would lead to a yery rough ontinte of 1/2,to 1 bilitan doilar nolise coet procilat with operation of this airport (olscounted at $10 \%$ por year) or roughly $\$ 5$ per pievenger uee at present. 
encounter difficulties with this method. Heathrow noise extends over low income housing where low prices do not reflect much consideration of amenities and where other noise is also prevalent. In additIon, Heathrow noise has built up over many years. so that people are somewhat accustomed to it. A study showed very little relation between NNI and housing prices under these conditions. " This presumably involves sone moving away of sensitive people and moving in of innensitive people but it also involves people who have been forcea to grow accustomed to the nuisance. for example people who cannot afford to wove, and children. 5 The low "market" cost of noiee associated with people who are poor or have grown used to it is not a reasonible value for ita cocial cont. similar arguments apply to many riske and nuisances, for example poseible low level radioactive pollution due to nucelar reactors. What are the monetary social coste of imposing this probably injurious burdan on a group of people? It could bo argued that a study based on extrapolated medical data and life insurance policies would reveal the value people associate with this risk, i.e.. "every man has his price." A proper cost-benefit analysis cannot simply rely on murket values in this kind of situation: Thus, even if we are fortunate enough to deal with an item for which market value may be well defined, particularly a poor man's price for accepting risk or loss of amenities, thin item will often, as a matter of cowunity interest, have a social value very different frcm the market price.

Thus, there is considerable uncertainty in assessing a cost such as nolse and subtle volue judgments are involved. There it an altornative to standard cost-benefit analy-

\footnotetext{
Daing the low local market evaluation the noise cost due to Heathrow would be very roughly $1 / 10$ of that mentioned in the previous footnote.
}

ysis in the case of envirommental amenities and safety. I will call it "constraintcost" analysis. Imagine the constraint that no more than $n$ people live in an area associated with aircraft noise about a certain index. There are several ways to help meet such a standard: Purchase of large areas of land about the airport site with use reserved for agriculture or industry, improvements of aircraft, lighter loading of aircraft, extreme flight pat terns, use of sites with over-water flight paths, limitation of traffic, etc. A full set of postulated constraints and of methods used to meet them would have to be considered together to evaluate the cost. The output of such an analysis would be the direct cost, plus perhaps certain indirect costs, as it varies with variation of the conetraints. The setting of constraints would be the point at which society would make its value judgments, rather than at the relatively obscure point of presetting social cost scales. in standard cost-benefit analysis. If a standard costbenefit approach were not made for certain difficult items it should still be possible to quantify many of them using constraintcost analysis. For any major project. there would still probably remain nonquantifiable considerations in adaition to the qualitative questions surrounding proper choice of constraints.

The difficulty with providing advice to the decision maker in a quantitative form is, then, that only some aspects of the project and its consequences can be satisfactorily quantified, and these may not be the most important aspects. We may gain perapective if we try to categorize various common inaices. The most widely discussed quantitative measures for the value of a particular or a model project are

Direct cost ac prevailing atandards Direct cost (constraints) Riak, loss of amenity" (constraints) 


\section{Demand (cost)}

Social benefit (cost, demand)

Social cost (risk, loss of amenity) Here all but the first item are functions of the item in parenthesis. The direct cost and social cost and benefit ${ }^{6}$ are expressed in dollars. The constraints are publicly imposed standards on the activity which will take the form of limits on environmental damage through monitored standards of physical performance. Risk is measured in loss of life and injury over suitable populations and time. Amenity loss can be quantified by various indices appropriate to the effect in question, for example a biological measure of lake eutrophication and trends in game fish populations. In many cases the amenity loss could be quantified in exactly the same way as the corresponding constraint. Risk and amenity loss are not quantified in dollars.

I have attempted to order the types of measures, in order of increasing difficulty of definition and evaluation, downward. I suggest that at a certain level of difficulty in this list, the quantities are so controversial of definition and/or so difficuit to determine that they are not useful. With this in mind let us go through the list: the direct cost, capital and operational, of a project of specified performance is a part of all engineering planning and design. We are aware that there are some difficulties of accuracy because of changing conditions and because we often are attempting to apply a new technology. similar remarks can be made about projecting costs as a function of various constraints. In many cases it will be very difficult to calculate the risk ${ }^{9}$ remaining in the presence of a particular constraint (e.g.. risk of cancer associated with a certain maximum level of radioactivity). The demand schedule, e.g., the use of electricity, and its projection into the future, as a function of the cost per $k w h$, are of course very difficult to determine accu- rately. The benefit calculation - one of the principal topics of this conference is fraught with difficulty of definition and evaluation intimately related to the problem of evaluating social cost illustrated above. The definition relative to production of a particular good must involve reference to demand schedules which show trade-offs that would be made if the good was available in greater or lesser amounts (i.e., at lower or higher price). $I f$, in the power industry, the demand curve considering competing sources of energy were available, one could attempt a definition of benefit which might comand acceptance. However it would still leave out trade-offs between consumption of energy and other activities; and it would still be simply a market place evaluation. Unfortunately the risk-benefit relationship postulated by starr ${ }^{6}$ is a aensitive relation: if the benefit change by a factor of 10, the "acceptable" riak change: by $10^{3}$ to $10^{4}$. Finally the calculation of social cost in dollars associated with risk and amenity 10ss, the dream of ane economists, is, in detail extermely controversial and difficult, as I have attemcred to illustrate.

In my opinion, the quantification becomes tooproblematical to be valid and useful somewhere in the middle of this list. Thus, thorough research might reveal a useful set of risk vs. cost and ant amenity joss vs. coat curves for a particular activity. Attempts to go too far toward obtaining an overal1 numerical evaluation should be resisted. The exact situation of course, depends on the size of error acceptable in the study, Usually, I linagine that there will be sharply competing needs for public investment so that, e.g. a factor of five uncertainty in an important cost item would render the number for that item useless. If this $1 \mathrm{~s}$, the item should be handled through development of inporved qualitative methods: better 
public education and participation, more effective probing of expert opinion, better basic education of decivion makers, diversity in types of adopted technologies, etc.

In conclusion I would repeat that the essential point about the quantitative aids to decision makers is that decision makers and the public are quite rational in suspecting that the numbers from any sxch study (excluding probably direct cost estimates) are not accurate enough for the purposes, because, indeed, they often will not be accurate enough. * It is relevent I think, that the heavily researched and highly respected Roskill Commiseion and$X s i s$ of London Airport sites resulted in a gite recomendation, which was, within 4 months, rejected by the British covernment and poorly racerrended alternative chosen. 8 The quantitative andysis was not sufficient.

*Indeed the particular ineccurate number positively bringe forth a eupicion of biag,

REFEREMCES

1. Report of the Comitesion on the mirhird Iondon Airport, F. Roski11, Chuirmen, Fer Majeety's stationery office. Iondon (1971).

2. "Noise: Final Report," Report of the wilson Counittee. Her Mjesty's stationary office, Iondon (1963).

3. k. Wullholland and $\mathrm{K}_{\mathrm{c}}$ Attanborough, New Scientist, March 19, 1971.

4. Camiesion on the Third Iondon Airport. Papers and proceedinge, Voll. vii, part 2. Chapter 20, Her vifesty's stationery office. rondon (1970). "second survey of Aircrett Hoise Annoyance Around Iondon (Heathrow) Airport," Hex Majesty's Stationery ofitce, Iondon (1971).

5. E.J. Mishan, whe Costs of Bcononic Growth," Penguin Books, Iondon (1968).

6. C. Starr, Science 165, 1232 (1969).

7. A. Neinberg, Ietter to the Editor. Science 174, 547 (1971). In principle Neinberg is too peseinistic about the difficulty of gaseseing low level "Insults" as he doos not allow for development of a basic theoretical undurstinding of the natural phenom monon.

8. There 1s, of course, wors to this story. H. Roes. "rondon's Third Nirport: Quantitative Decieion inking." to be publishod. 
In previous papers" addresed to the cenoral queation of "How safe la safe enough?" It has been shown that the public accegits very much greater risk from voluntery exposure than it doex from involuntary exposures imposed on the public by socsatal decteions. While thit difrerence can be summarised by the statement "We aro loathe to let others do unto us what we happlity do to ourcelves". the cause $x$ such a differance of several ordare of magritude in the public accoptabluty of risk exposures deserves surther elueldation.

In this discusation I would like to explore the poustble factors which micht infuence such a wido d!screpancy in public attitudes. It is almost immediately evident that the Individual may pereate the values and riaks ascociated with any setivity in a manos quite dirferent then that which wousd reprosant an objective overall societal evaluation of the same factors. For the purposet of this discusstion, I will assume that for any given sociotechnical aystem there exiats an average riak which cas be objectively evaluated in terms of frequincy verous severity for accidents which expose and damage the public. Assume also that in those cases where a men-machine internction is lovolved, that the average of such interections over the total population is sufriciently consistent that such a socletal evaluation is a reliable objective base. The trus public risk ts then the incegral of the frequency

\footnotetext{
Sclence, 19 September 1869, volme 165, pages 1232-1238.

NAE Colloquim on Banofit-Riak Relntionthipe for Deciation-Maldos, Washington, D.C.. April 26. 3971
}

versus saverity cusve, and can be reasonably expresead in a simplified quantitative manapr.

There do a coneral distinction that can be made between halithy rlok-taling in the norinal activities of a popelation, and neurotic riak-iageing or aulcidal impulese. This latter ney bestinsidered a medical illness to be treated paychiatrically. For want of a better dafinition, I am consldoring individual healthy risk-talding as that type of activity which results from a besifit-riak analyale (consclous or unconsclous) which indicates that the benefite are sufficlently large to justify the riake. This definition assumes that the great majority of the population has an averelon to riak. For example, the swimmer or boater doesn't expect to drown, the tennis player does not expect to have a heart atteck on the cours, the eltior doesn't expect to break a les. and the hunter doesn't expect to get shot. In all these cases, of coures, the individual reblines there is some risk of these eventualitios but assumes that they are small compared to the beneCits to him of the sctivity.

In this discusation, I am ulso separating riak to phyolcal health from the uncertainties of challonges to inan' a skdlls. Such sturations can be provided by card jumes, chess gamed, Hganw pusales, fordign travel, hiking, and other exploratory activitias both intellectual and physical. I am assuming that the exhllaration aceociatod with meeting such challenges is part of the rewards connected with the activity and is a normal part of a healthy plessure stimulus. 
Even with the assumption that it is possible to expreas a risk frequency versus severity curve for our mrjor activities, it is clenr that one curve would not be applicable to describe the risk situation for each indiridual in a voluntury autivity. For example, one might plot the frequency of automoblle accidents versus their severity for the population of the United States. This curve however, woukd not be a proper evaluation of the risk situation for the individial driver. We know that the caretil driver is lese prone to have accidents tran the average. We know that there are sufficlent variations in driving sill that under certain circimatance an individual will evade an accident which intght develop for the average.

In fact, it is evident that in alinost every voluntary activity which an individual undertakes. there is a wde opread in the ability of the individual to manas the aituation which produces the risk. I am fifirclore sugfosting that the opportunity to manas siak situation is one of the busic determiners witch distingushes individual acceptance of voluntery rieke, as compared with involuntary exposures: Thus, the automoble driver who feele confdedis that he can handle his vehiclo on a wet or icy roaci at high apeed may oveluate the rak sltuation quite differently frmm ove who is incepable of handlix oven a mild slete. The expert alder will presume that he is loes prons to have accidenta on the slope because of hie ability to meneuver in and out of difficult situation. Perhape the most common example is that of the ordinary ldtchen loife - en inctrument which causes thousand of cuts and other infuries esch year. Yot, it is an instrmnent which we all confidently use on the asrumpticon that we can minimize our individual risk by our enratul handling. In contrast, If someone else wields the inde on something we are holding, our increased caution due to the abrence of self-manegement becomes evident.
We have a mcre revealing aituation in the case of automobile safety belts. In spite of the very valid evidence that the use of aafety belts will decrease the physical infuries resulting from as automobile accident, only a Bmall fraction of the population uses these. It is evident that the individual driver must belleve that his ability to manage the awkward situations which lead to drivIng accidents is sufficiently great that the add:tional safety provided by the belt (loes not justify the nuisance of using it.

An essential element if our individual confidence in Hak management is the extent of our familiarity with the risk oltuation. An unfamiliar, but parceived, Mak involves oufficient uncertaluty that the cautious approach of the individual is te estimate ite magnitude on the high side. In addition, the specific characteriatics of the risi may also be unclear, leading to doubts concerning its manageability by the Individual. We have many common examples in our lives - an unusual severe pain, walbing in the darix in uniamiliar surroundings, driving in a dense fog, etc. The public' : fear of radiation shows many of these characteriatics. Thus, the mere act of living and coping adequately with a potential Mik situation for an extonded time provides an ingredient of familiarity which increases our confidence to manage a risk when it occurs. This attitude of the Individual may have litle connection with the objective probabilities and consequences of the eiturion.

A diferent type of situation is that which is Illuatrated by the recent studies on deaths due to heart diseage. It has been eatimated that in the United States 800,000 deathe anmully can be attributed to arteriosclerosis, commonly known as "hardening of the arteries". The evidence is very clear that this is a situation which usually develops from Hfelong eating habits associated with high fat diets. In apite of this rather significant currelation betweon death and a cause, it 
is apparently very difficult to significantly alter the eating habits of the American public. I belleve that part or the difficulty is that our daily pleasure in eating is an immediate reward. The penalty may be decades away. Thus, it is possible that in the perception of risk, the individual undertakes a present value (or future discounting) approach in his unconscious evaluation of the risk.

One might therefore hypothesize from these examples that the perception of the individual is highiy influenced by his presumed ability to manage the risk-creating situation, Thus, even with knowledge of the societal average for the statistical risk associated with an activity, the individual presumes that he can "beat the game" by his own special abilities in handling the situation. Secondly, we may also hypothesize that present benefits which might result in future risks involve an unconscious discounting process which must be considered in evaluating individual behavior.

The other side of the equation-the benefits also vary when the individual is compared with the societal average. As I pointed out in my early paper on the subject, the public perception of the benefits of an activity may often be heavily influenced by subjective factors not related directly to its primary utility. I presented in that paper an arbitrary function called "benefit awareness" which was defined as the product of the relative value of adyertising spent on the activity, the square of the percentage of population involved in that same activity, and the relative usefulness or importance of the activity to the individual. As pointed out in that paper, there seems to be a very close correlation between this "benefit awareness" parameter and the public acceptability of risk levels. Of course the most startling example of the effect of sdvertising and large group participation is our very popular custom of cigarette smoking. Even admitting that there is a real utility for the smoker in the activity, the public acceptance of the risk is very clearly the result of social usage and heavy advertising.

An extreme case of poor public perception of benefits is provided by those social services whose primary function is to minimize the impact on the public of the operations of large sociotechnical systems. Our public health systems and other efforts we undertake to clean up our environment are generally very poor:y percelved by the individual. In fact our national anti-ijtter campaign inherently assumes that the individual has a very low perception of the damage caused by his careless habits. It is only when the physical environment surrounding an individual becomes sufficiently oppressive that he can correlate his discomfort with the operation of a technival system, that he specifically focusses on ameljorating that condition. In this respect, the organized effort to advertise the environmental impacts and to make a social good of a clean environment is directed to developing an individual perception of the benefits to be derived from environmental controis.

Individual evaluation of risk and benefit situations are usually compounded by the fact that it is relatively rare for the benefits and risks to be focussed only on the individual participant. It is much more cuatomary to find one factor dispersed throughout society. It is certainly clear that in auch situations the normal perception of the individual of the acceptable trade-off between benefit and risk is not likely to be that of the sncietal perception of the same situation.

In particular, the societal costs associated with a risk situation are apt to be widely different than those perceived by the individual. For example, the young hot-rodder speeding his car down a highway may not be concerned with the major investment which society has made in supporting him through his growing and educatiomal period. In geseral, the social investment in 
biringing a pepulation age-group to a productive stage is rarely a matter of concern to that group. On the riak side of the equation, we have a fimilar Imbaiance. Except for the terminal risk represented by death, most other physical damage produces a social burden of long duration of which usually only a fraction is borne by the individual. We have all seen the evidence of a societal obligation to carry for an individual a medicul burien, a genetic burden, and a welfare burden, with an overall effect on reclucing the general quality of life in the soziety.

If these hypotheses are correct - that indeed the incividual perception of risk and benefit assoclated with the various activities involved in our complex socio-technical society aro markedly different from the perception of a national planning or policy group, then the difference betwean the public approach to voluntary activities as compared to involuntary would be expected. If one consiters the problen of the application of national ramources to improving the quality of life of the population as a whole, it becomes iniportant that ihese resources be allosated on the busis of their maxinum marginal utility, objectively evaluated for snciety as a whole. With the individual perception being widely different from that of a societal evaluation, a key imcompatibility develops.

Hopefuliy. contiruous public education anu increased public participation in the management of involuntary exposures through the political system may reduce this hurdle of publie acceptance of socially degirable decisions. Pragmatically, pubilic participation in confusingly coinplex national issues is usually conducted through either representatives of interest groups or by the leadership of authority figures. Our society's administrative problem is how to provide a workable mechanisim for such participation in the management of public riaks. 
LIHITATIONS OF THE MIND OF MAN: IMPLICATIONS FOR DECISION MAKING IN THE NUCLEAR AGE ${ }^{1}$

\author{
by \\ Paul Slovic ${ }^{2}$
}

Oregon Research Institute

Eugene, Oregon

\begin{abstract}
"Statistical chinking will one day be as necessary for efficienr citizenship as the ability to read and write." $--H$. G. Wells
\end{abstract}

The question 1 wish to discuss today, frem a psychological standpoint, is whether man is capable of the kind of high-level thinking and reasoning that decision making in the nuclear age will roquire.

Just what kind of thinking do we need when making decisions atsut nuclean power? Such decisions demand all understanding of the probabilistic nature of the world and they demand the ability to think in probabilistic terms. They also require the ability to make forecasts, predictions, and evaluative judgments on the basis of fallible on incomplete data. Because statistics is a formal discipline designed to help people evaluate information and make decisions in the face of uncertainty, I shall refer to this kind of thinking as "statistical thinking."

Most of the time when we make jucionents and decisions, we bypass formal statistical reasoning

\footnotetext{
I Presented at a symposium entitled: "RiakBenefit Analysis: Solution on Dream?", sponsored by the Hestem Interstaie Nuclear Boand--Los Alamos, New Hexico, Norember 12, 1971.

${ }^{2}$ The writing of this paper was auported by Grant MH-12972 from the Natioral Inatitute of Nental Health. The author is indebted to Daniel Kahneitan and Nwos Trersky for permiseion to cite some of, their unpublished data and for their comments on the general presentation.
}

and when we do th's we are acting as "intuitive" statisticians. There have been a number of neceint studies pertaining to the adequacy of our performance as intuitive statistlcians and I think many of these studies have important implicationa for dealsions relevant to the development of nitcleap' power. In general, these studies have unoovered some surprising and rather disturbing deficlenoles in man's: ability to trink in probabiliatic terms on to bal ance risks against benefits when making decisions,

\section{BIASED JUDGMENTS OF PROBABILISTIC EVENTS}

Because of the importance of ptobtibllistic red soning to decision making, fair amount of effort was bein devoted to studying how people pelceive, process, and evaluate the probibilitice of unortalt events. One basic conclusion from this reseanch 1 s that probar ilistic judguents show Iange and oons $f(4)$ tent biases that are quite difficuit to bilminated

\section{Understanding Random Sampling}

The "law of small numbers on oxample of man's Inatequacy as an Intuitive statistician coka from a study by Trersky and Kahneman $(1971 \%)$, kho enalyzed the kinds of decistons psychetoglsts make when planning their sciontiflo experlyphts Doepit extensive formal training in statistice, poychologists usually rely upon their educated intuitions when they mike their decisfons about how lantes salple of data to collect or whether they hougd repeat an experiment to wake sure thefr toults on reliable. 
After questioning a number of psychologists about their research practices and after studying the designs or experiments reported in psychological journals, Tversky and Kahneman concluded that these scientists had seriously incorrect notions about the amount of error and unreliability inherent in small samples of data. They found that the typical psychologist gambles his research hypotheses on suall samples without realizing that the odds against his obtaining accurate results are unreasonably high; second, he has undue confidence in early trends from the first few data points and in the stability of observed patterns of data. In addition he has unreasonably high expectations about the replicability of significant results. Finally, he rarely attributes a deviation of results from his expectations to sampling variability because he finds a causal explanation for any discrepancy.

Tversky and Kahneman summarized these results by asserting that people's intuitions seemed to satisfy a "law of small numbers" which means that the "law of large numbers" applies to small samples as vell as to large ones. The "law of large numbers" says that very large samples will be highly representative of the population from which they are drawn. For the scientists in this study. small samp.les were also expected to be highly representative of the population. Since his acquaintance with logic or probability theory did not make the scientist any less susceptible to these cognitive biases. Trersky and Kahneman concluded that the only effective precaution is the use of formal statistical procedures, rather than intuition, to design experiments and evaluate data. ${ }^{3}$

In a selated study, this time using Stanford University undergraduates as subjects, Kahneman and Tversky (in press) found that many of these subjects did.not understand the fundamental principle of sampling, namely, the notion that the emos in a sample becomes smller as the sample sizs gets larger. To illustrate, considen one of the questions usad in this study.

\footnotetext{
3 people are not always incautious when drawing infexences from samples of data. Under sunowhat different circunstances they becone quite conservative, responding as though data are much less diagnostic than they truly are (see Edwands, 1968).
}

"A certain town is served by two hospitals. In the larger hospital about 45 babies are born each day, and in the smaller hospital about 15 babies are born each day. As you know, about $50 \%$ of all babies are boys. The exact percentage of baby boys, however, varies from day to day. Sometimes it may be higher than $50 \%$, sometimes lower.

"For a period of one year, each hospital recorded the days on which more than $60 \%$ of the babies born were boys. Which hospital do you think recorded more such days?

"Check one:

a) The larger hospital.

b) The smaller hospita.l

c) About the same (i.e.. * of days were within 58 of each other "

About 248 of the subjecto chose answer $a, 208$ chose $\underline{h}$, and 568 selected $c$. The correct answer is, of course, b. A deviation of 108 or more from the population proportion is much more.likely when the sample size is small.

Kahneman and Trersky concluded that "the notion that sampling variance decreases in proportion to sample size is apparently not part of man's repertoire of intultions. For anyone who would wish to view man as a reasonable intuitive statistician, such results are discouraging.

Judgments of Comrelation and Causality

Next, let's look at arother facet of statist1cal thinking--the perception of comelational relationships between pairs of variables. Correlation between. two variables means that knowledge of one will enable you to prealct the value of the other. Chapman and Chapman (1967, 1969), studying a phenomenon they have labeled illusory comselation, have show how one's prior expectation of a relationship between two variables can lead him to perceive correlation when it does not really exist. They found that most subjects learned to see what thsy expected to see even though there wexe no real correlations in the data they were shomn. The Chapans noted that in many decision situatlons' an expent may. be reinfored in his obsemvitions of 11lusory correlates by the reports of his colleaguins, who themselves may be subject to the sim illivions. 
Such agresicent among experts is, unfortunatoly, often mistaker as evidence for the truth of the observation.

Several studies have investigated subjects' perceptions of comelation and causality in simple situations involving just two binary variables. Consider a $2 \times 2$ table in which variable $A$ is the antecedent or input variable and $B$ is the conseguent or autput variable and the small letters are the frequencies with which the levels of these variables occur together.

$$
\begin{array}{ccc} 
& B_{1} & B_{2} \\
A_{1} & A_{2} B_{1}=a & A_{1} B_{2}=b \\
A_{2} & A_{2} B_{1}=c & A_{2} B_{2}=d
\end{array}
$$

A correlation or contingency exista botween $A$ and $B$ to the extent that the probabllity of $B_{1}$ given $A_{1}$ differs from the prabability of $\mathrm{B}_{2}$ siven $\mathrm{A}_{2}$; that is, to the extent that $a /(a+b)$ differe from $c /(c+d)$. If $B_{1}$ is as $11 k$ ly to occur given $A_{2}$ as it is given $A_{1}$, there is no correlation between $A$ and $B$.

Research Indicates that subjects' fudgents of contingency are not based on a compurison of $a /(a+b)$ versus $c /(c+d)$. For exemplo, sindslund (1963) had students of nureing fudge the rolution between a symptom and the diagnost of a disense. He found that the judgments wore bued ainly on the frequency of foint occurrence of grptom and disease (cell a in the watrix), without taking the other three event combinations into account. As a result, the fudgants ware umelated to actunl contingency. Similar results were obtained by Jeakine and Hand (1965) and Vand and Jenkins (1965). Wand and Jenkins conciuded:

"In zenere: . . statistiondy naive subjects lack an abetrest ooncept of contingency that is Iscmorphic with the stivtiaticel copent. Thowe who receive informetion on a trial by trlal basis, as it uevally ceenes in the ronl world. gonorilly fall to anems adequateiy the depe of relntionohp present $[p, 240]$."
A recent examplo in the nowepupen illuatrates several of these blases. A womn anked Ablyail Van Buren the following question: "Dear Abby: Why do so any people say that anifuan is harmleas? Ow daughter bogan using it is January. She wont on to nescaline in Marcli, and was in a montal hoopital in July." Ably roplied that warifuana apporatily can be destructive to som individuals and theme is no way of knowing who can handle it and who cannot.

Thus we see that the womn who esked the queation and Abby were both drawing an inference cibout the relationship between narifuan and later problows on the batis of a very enall exple (1 are) that fell in cell a of the $2 \times 2$ table shown above.

\section{Jud onente of Probobisity}

Availubility bles. One source of distontion in probabi2ity estinates that any be quit, relevant to ovaluation of the alake involved in nuclean poner is the notion of "avaliablifty bias," Tverely and Kahnean (1971b) found that one owe that we use when fudgins the probubility of an event is the anee with wich relovant instances of that wifit are inglined. Another cw is the nuber of such Inotinces that are readify remabered. The avaisatility of Instences is affected by factore auch as reoncy, enilency. and inginability wich ny, but need not, beap any relation to the enent'a probublilty. For apoplo, the lettar $k$ is three time a ikely to apposin as the thind 1etter of an Briblish word an the flret

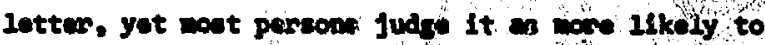
be a flet 2atter. Tranky and kabpinan pypothesies that, when oubjects rike this judpint, they toy to think of wonde eithw beglinolne with $k$ os havin $k$ al - thind letter. It is everer to thisk of monde that

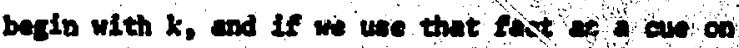

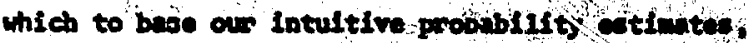
these wons will be poreined of ane probels the th monds wht $k$ in the thind positton. In fownol, the

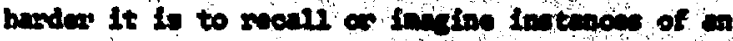

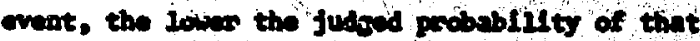
enent:

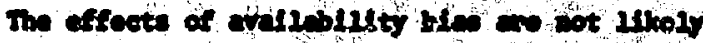

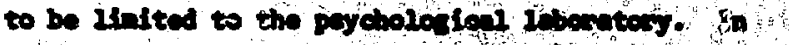

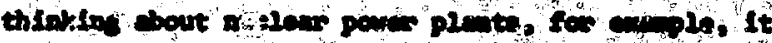


Is not difficult to conceive of circuretances that could wake a serious accident highly available or Inaginable--a recent accident or a vivid fill or lecture could do the fob. Such incldents could lead to considerably inflated estinutes of the probabil. ity of such an accident.

Value bies. Other studies have found that the desirability of an event blases its subjective probability. athough the effects aro complex and differ fren person to person (Slovic, 1966). Some people are overly optinistic, tending to attribute greater probalility to highly-desired events then to undesired avents, otion factors beins equal, Other persons are pessinistic. They consfstently overestivate the Ikelihood of uppleasant events.

Compound evente. One feature designed to nininize the ritak of a nuclear accident is the syatem of wultiple safeguands whereby a brokkdown would occur only if each of a nubar of independent componente falled sinutaneously or in clane equance. When components are independent of one another. thair jolnt failure is a canpound event wone probability it einply the product of the pobabilities that each individual component will fall. Soveral stulies have ehow that the porceired probability of compurl events is wore siviler to the en, rather than the product, of the component j.oblbflities. thus the probubility of the compound went is overestianted (Slovic, 1969).

\section{Preblen in Qune ifyin oncenteinty}

One of the acse Interesting and Inportent types of bies in 112ustrated in studies conduoted by A1pert and Ruiffa (1968) and Trasky and Kohnomen (1478). In both of these etudles, oubfects were given "lunde question" aich is the sallosing:

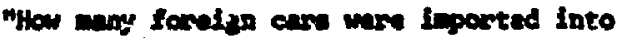
the U.S. In 1962 ?

a) Ane a bigh cotingte nueb that you Ieal there is only a 19 probsility

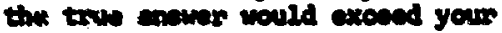
estlinats.

b) Hike a 20 estingte euch that you fiel there is coly a is probibility the twe ogmer would bo belen this estinte."

In secoes, the cabject is boling aked to ent1-

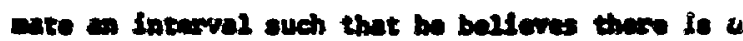

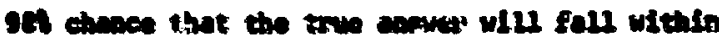

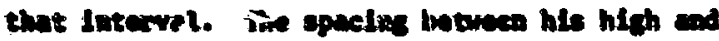

low estiantes is his expreseion of what he knows or dosen't know about the quantity in question. We cannot say that this single pais of estimates is right or mons. However, if he ware to make many such estimates or if a large number of persons were to arswar this question, we should expect the band between upper and lower estimates ts include the truth about 981 of the tine--If the subjective probabilitias were velid. What is typically found, however, by Aipert and Raiffa and by Treraky and Kahneman, is that the 98 s confidence band fails to include the true value from 40 to 50 of the time, across any subjects anawering many kinds of aimanac questions. In other words, subjects' confidence bands wa wuch too narow, fiven their state of kmowledge. Alport and Ralffa obsewred that this bius peraloted even when subjecte wers given foedbeck bout their overly narrow confidence bunde and exhorted to widen the bands on a new set of estimation problems.

These etudies indicate that people believe they have a much better picture of the truth than they realiy do. Why this happens is not entlrely clear. Traraky and Kahminen tentatively hypothesize that prople appronch these problews by searching for a calculational schese or algonith by which to estiate the envwer. For exaxple, In unawering the above queation ore aight proceed as follows:

"I think there were about 180 millfoid people In the U.S. In 1968; thare is bout one en for every thres people thus there would havs been about 50 millfon ene; the lifetine af a cas if about 10 yours. this surrests that there stiould be bout 6 allilon now cars in a year but eines the pepalstion and the number of cros is incressing lot's whe that 9 allition for 1968; foreifn cars make up about 204 of the U.S. mirket, thus there were probably bout 900,000 foretion inporce; to set my 984 confldance band, I'll add and subtruct a few hundred thound care tron in extingte of 900,000."

Treosky and lahnemen wros that people's estinntes are conditiond an the vilidity of their computational inowithm. Hownen, these are two soures of uncertaluty thot plegu these algorithes. Flret, these is unowraticy at every ateg in the sequential cotination poese and thase is vacextalnty bout the acroftho itself. The is, the whole relcu-

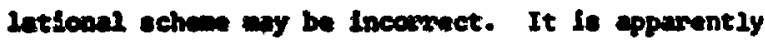
qufte difficule to oury alon these soveral sources of uncurainty and traplate them intuitivaly inte a 
988 confidence band. Once the "best guess" is aprived at $(0.8$. , the 900,000 figure above) the token adjustments fail to do justice to the many ways in which this estimate could be in emror.

The research just described implies that our estinates win be erossly in error-even when we attempt to acknowledge our uncertainty. This may have profound implications for many kinds of Judgments about the risks and benefits associated with nucleas power-for example, judgments about the operating lifetine of a certain nuclear plant or the durability of a vessel storing sadioactive wastes. Estimates of future costs are particularly likely to be susceptib?.e to this kind of bias.

\section{PROBLEAS IN INTEGRATING INFORYATION}

\section{FROH MULTIPLE SOURCES}

Tinus far, the discussion has been concerned with the susessment of risks and estimation of uncertain quantities. At this point I would like to turn to a somewhat different problem. Suppose thot we have good injormation about both risks and benefits. How capable are we of balancing these several factors and coming up with an optimal decision? By optimal, I don't mean a decision that will, necessarily, tum out well. Some good decisions work out poorly and vice versa. I'm thinking of optimal decisions in the sense that such decisions fithfully reflect the decision makeris personal vajues.

As if we didn't have enough problems with our tercioncies to blas probability judgments, there is some avidence to the effect that our informationprocessing limitations may often lead is into declslons that are inconsistent with ou: underlyjing values. One example of this within a risk-benefit

\footnotetext{
${ }^{4}$ For exaralin, the cost of major weapons systems is cunning nearly 508 ahead of oxiginal estimates according to a recont congressional study team. In ons case the original estinnte for 6 submarine rescue vehicles was 18 million dollars. Later the es cimate was revised to 463 miluion dollars! This overrun, like wost of the others, was blaned on a failure to foresee developmant problems. There are many ways our judgwonts can go wrong, and it is difficult to incorporate our uncertainty about these possible sourees of exror into our actul fudgments.
}

context comes from a study by Slovic and Lichtenstein (1968) in which subjects were asked to indicate how much they would like to play various gambles for which the probabilities of winning and losing and the winning and losing payoffs were stated precisely.

The experiment was straightforward. One group of subjects rated the attractiveness of playing each of a number of gambles on a ten-point scale. Another group of subjects indicated the attractiveness of these same gambles by a method in which they put a price tag on each to indicate its worth ro them. That is, they stated an amount of money such that they would be indifferent between playing the gamble and recelving the stated amount. In addition, some of the subjects in both of these sxoups indicated their subjective weightings for the four risk dimensions of a gamble (1.e., probability of winning, probability of losing, amount to win, and amount to lose) by distributing 100 points over the set of dimensions according to their feelings about the relative importance of each dimension. When subjects rated the attractiveness of a gamble, probrbility of winning was found to be the most important dimension. When they put a frice on a gamble, attractiveness was determined more by the gamble's payoffs. Yet subjects in both groups stated that they valued probability of winning as the most important considera- tion. Apparently, there was a fallure to properly implemert this ralue when making the pricing responses.

A later experiment (Lichtenstein 6 Slovic, 197!) replicated the response-mode effect. Consider the following pair of gambles:

Bet $A$ : .90 to win \$ 4 and .10 to lose \$2

Bet B: . 30 to win $\$ 16$ and . 70 to lose $\$ 2$

Bet $A$ has a mici better probability of winping but Bet $B$ offers a higher winning payoff. Lichtenstein and Slovic's subjects were shown many such pairs of bets. They were asked to indicate, in two ways, how much they would like to play each bet in a pair. Finst they made a simple choice, A as B. Later they were asked to assume they owned a ticket to play each bet, and they were to state the lowest price for which they would sell this ticket.

Presumably these selling prices and choices are both governed by the same underlying quality, the subjective attractiveness of each gamble. 
Therefore, the subject should state a higher selling price for the gamble that he prefers in the choice situation. However, the results indicated that subjects often chose Gamble $A$, yet stated a higher selling price for Gamble B. Why should this happen? Lichtenstein and Slovic have traced it to the fact that subjects used different cognitive strategies for setting prices than for making choices. Subjects choose Bet $A$ because of its good odds, but they set a higher price for $B$ because of its large winning payoff.

A "compatibility" effect seemed to be operating here. Since a selling price is expressed in terms of monetary units, subjects apparently found it easier to use the monetary aspects of the gamble to produce this type of response. Such a bias did not exist with the choices since each attribute of one gamble could be directly compared with the same attribute of the other gamble. With no reason to use payoffs as a starting point, subjects were free to use any number of strategies to determine their choices. In most cases, they relied primarily on the probabilities of winning and losing. When faced with their inconsistent decisions, many subjects had a very hard time changing either of their conflicting responses. They felt that the different strategies they used for each decision were appropriate. However, strict adherence to an inconsistent pattern of prices and choices can be termed imational, since the inconsistent subject can be led into purchasing and trading gambles in such a way that he continually loses money.

The overdependence on payoff cues when pricing a gamble suggested a general hypothesis to the effect that the compatibility or commensurability between a cue dimension and the required response effects the importance of that cue in determining the response. This hypothesis was tested in a recent experiment by Slovic and MacPhillamy (_971), who predicted that dimensions colmon to each alternative in a choice situation would have greater influence upon decisions than would dimensions that were unique to a particular altemative. They asked subjects to compare pairs of students with respect to potential college Grade Point Average. The suifjects were given each student's score on two cue dimensions (tests) on which to base their judgments. One dimension was common to both students and the other was unique. For example, Student A might be described in terms of his scores on Need for Achievement and English Skill, while Student B might be described by his scores on Quantitative Ability and English Skill. For this example, since English Skill was a dimension common to both students, it should be weighted heavilly. That is, a comparison between two stimuli along the same dimension should be easier, cognitively, than a comparison between different dimensions, and this ease of use should lead to greater reliance on the common dimension. The data strongly confirmed this hypothesis. Conmon dimensions were weighted much more heavily than unique attributes. Interrogation of the subjects after the experiment indicated that most did not wish to give more weight to the common dimension and were unaware that they had done so, illustrating again a systematic deficiency in judges' ability to implement their subjactive values.

The message in these experiments is that the amalgamation of different types of information and different types of values into an overall fudgment or decision is a difficult cognitive process and we often resort to fudgmental strategies that may do an injustice to our underlying values. In other words, even when the risks and benefits are known and made explicit, as in the gambiing situation, subtle aspects of the decision we have to make, acting in combination with ow intellectual limitations, may bias the balance we strike between these risks and benefits.

\section{ARE IMPORTANT DECISIONS BIASED?}

Experimental work, such as that just described, documents man's difficulties in welghing information and judging uncertainty. Do these difficulties diminish once the subject leaves the artificial confines of the laboratory and resumes the task of using familiar sources of information to make decisions that are personally important to him?

While there is little systematic evidence bearing on this istion, there are some hints, at least, that man's information-processing limitations do influesce decisions outside the laboratory. For example, there is extensive data indicating that the risks of natural hazards are grossly misperceived (Kates, 1962; Burton \& Kates, 1964). 
Slovic, Kunreuther and White (1971) discuss the close parallel between the nature of these misperceptions and the biased judgments of probabilities found in psychological experiments.

Examination of business decision making and governmental policy making suggests that, whenever possible, decision makers avoid uncertainty and the necessity of weighting and combining information or trading-off conflicting values. For example, Woods (1966; p. 95) summarizes his observations of one business firm's jinvestment strategy as follows:

"In estimating the value to their company of a potential investment, the managers in the organizations studied are preoccupied with searching for a comparable prior investment rather than identifying the relevant varias?es and forecasting the underlying uncertainty. Uncertainty is avoided like the plague, while the certainty of historical information is accorded such a premium that it dominates the managers' mental processes completely."

Cyert and March (1963; p. 120) also note the

avoidance of uncertainty by business firmo.

"Our studies, however, lead us to the proposition that firms will devise and negotiate an environment so as to eliminate the uncertainty. Rather than treat the environment as exogenous and to be predicted, they seek ways to make it controllable.

". . one conspicuous means of control is through the establishment of an industry-wide conventional practices.

"For example, prices are frequently set on the basis of conventional practice. With time such variables as the rate of mark-up, price lines, and standard costing procedures becone customary within an industry. The net result of such activity . . Is that an uncertain environment is made quite : ghly predictable."

Lindblom (1964) comes to similar conclusions on the basis of his analysis of governmental policy making. He notes that administrators avoid the difficult task of taking all important factors into consideration and weighing their relative merits and drawbacks. Instead they employ what he calls "the method of successive limitad companisons." This method simplifies decisions by comparing only those policies that differ in relatively small degree from policies already in effect. Thus it is not necessary to undertake fundamental inquiry into an aiternative and its consequences: one need study only those respects in which the proposed alternative and its consequences differ from the status quo.

The decision makers studied by Cyert and March and Lindblom were also found to avoid long-range planning and forecasting. They preferred to take small steps and to monitor short-run feedback rather than to try to predict the consequences of a longrange move.

The avoidance of uncertainty, the avoidance of "weighing relative merits and drawbacks," and the avoidance of long-range forecasting are just what one would expect, given what the laboratory strilies indicate about our cognitive limitations. When we can use feedback as a guide--that is, when we car. afford to learn by our mistakes, such behavions may be satisfactory approximations to optimal performance.

\section{IMPLICATIONS FOR DECISIONS REGARDING NUCLEAR POWER}

I'd like to conclude with some additional speculations about the possible implications of this research for decisions bearing upon the development of nuclear power.

First, we all acknowledge the importance of personal values and subjective probabilities in guiding our thinking about nucleas powers but how can these probabilities and values be measured? We can infer them from oun overt actions or vie can ask people to estimate then directly. The probiem is that different estimation methods impose iffiferent modes of thought that, in turn, may produce quite inconsistent results. Knowing how response biases operate, however, may help us detemine the best way to elicit an individual's opinions about risks and benefits. At present, the technology for assessing these subjective opinions is primitive and awaits development.

Second, it seens quite likely that there will continue to be very great disameenents betwen the forecasts and perceptions of engineers and scientists on the one hand, and the public or the other Each group is subject to error-especially when good empirical data is lacking. The technical people may run into problems because of an inability to nuantify what they don't know--as indicated by the almanac experiments described above. The public may go 
astray because of availability biases, wherein very subtle factors play upon imagination and memory in a way that alters the percaption of risk.

If our intuitive judgments are so poor, why do we have such great confidence in them? For one thing, our basic perceptual motor skills are remarkably good, the product of a long period of evolution, and thus we can process sensory information with remarkable ease. This may fool us into thinking that we can process conceptual information with similar facility. Anyone who has tried to catch a baseball by calculating its impact against the bat, trajectory of flight, etc., knows, however, that our analytic skills lag far behind our sensory abilities.

Man has faced decisions of great consequence, like those involving nuclear energy, only within his recent history. It might be argued that he has not had enough opportunity to evolve an intellect capable of dealing conceptually with uncertainty. He is essentially a trial-and-error learner and his early experiences with nuclear energy give little assurance that he can change his ways even when errors will be quite costly (see, for example, Schrader, 1971). How does such a creature learn by experience yet avoid catastrophe in the nuclear age? A pessimist might advise him to take very small steps--small enough so that he can recover from the inevitable miscalculations. An optimist would reply that the technology of decision making will undoubtedly advance rapidly within the next decade. Perhaps with proper educational techniques, computer simiations, and sophisticated methods of decision analysis, we will be able to minimize many of the types of judgmental biases discussed here, Then, if the balance between benefits and risks is fudged favorable, the development of nuclear power could proceed at an accelerated pace. And the cynic, noting the aforementioned tendency for psychologists to overgeneralize on the basis of small samples of data, would advise us to disregard the research on biases and continue to have iaith in our intuition.

Time will tell.

\section{REFEREWCES}

Alpert, M., 6 Raiffa, I1. A progress report on the training of probability assessors. Unpublished Manuscript, Harvard University, 1968.

Burton, I., 8 Kates, R. W. The perception of natural hazards in resource management. Natural Resources Journal, $1964,3,412-441$.

Chapman, L. J., \& Chapran, J. P. Genesis of popular but erroneous psychodiagnostic observations. Joumnal of Abnommal Psychology, 1967, 72, 193204.

Chapman, L. J., \& Chapman, J. P. Illusory correlation as an obstacle to the use of valid psychodiagnostic signs. Journal of Abnomal Psychology, 1969, 74, 271-280.

Cyert, R. M., 6 March, J. G. A behavioral theory of the firm. Englewood cliffs, N. J.: PrenticeHall, 1963.

Edirards, W. Conservatism in human information processing. In B. Kleinmuntz (Ed.), Formal representation of human fudrment. itrw York: Wiley, 1968. Pp. 17-52.

Jenkins, H. N., \& Ward, W. C. Judgment of contingency between responses and outcomes. Psychological Monographs, 1965 (79, Whole No. 594).

Kahneman, D., \& Tversky, A. Subjective probability: A judgment of representativeness. Cosnitive Psychology, in press.

Kates, R. W. Hazard and choice perception in flood plain management. Department of Geography Research Paper No. 78, University of Chicago, 1962 .

Lichtenstein, S., Slovic, P. Reversals of preference between bids and choices in gambling decisions. Journal of Experimental Psychology, $1971,89,46-55$.

Lindblam, C. E. The science of muddling through. In W. J. Gore E J. W. Dyson (Eds.), The making of decisions, New York: Free Press, 1964. Pp. 155-169.

Schrader. 6. Atomic doubletalk. The Center Magazine, 1971, 4, 29-51.

Slovic, P. Value as a determiner of subjective probability. IEEE Transactions on Human Factors in Electronics, 1966, HFE-7, 22-28. 
Slovic, P. Menipulating the attractiveness of a gable without changing its expected value. Journal of Experimental Poycholoy, 1969, 79, 139-145.

Slovic, F., Kunreuther, H., 6 White, G. $\Gamma$. Decision processes, rationality, and edjuntwent to nácural hezrunds. 1971, in prepuration.

Slovic, P. \& Lichtensteis, S. 'the rolative ieportance of probabilitles ant puyoffe in rigk taking. Jouppal of Experinentif Pexcholor, Honogxaph Sypplement, 1968, 78, No. 3, Pant 2. Slovic, P., \& MacPhillary, D. Dimansional comensurability and cue utilization in vomparative judgment. Oreron Resenrah Institute Resermeh Bulletin, 1971, Vol. 11. No. 14.

Smedslund, J. The concept of correlation in adults. Scandasavian Journal of Paycholory, 1969, 4, 165-173.
Trareky, A., \& Kahneman, D. The bellef in the $1 \mathrm{~m}$ of sull numbre. Paycholorical Bulletin. 1971, 76, 105-110. (a)

Tremky, A. \& Kahneinan, D. The judpont of frequenC5 and peobability by availability of instances. Groron Receunch Institute Resench Bulletin, 1971, Vol. 11, No. 6. (b)

Wend, H. C., Jenkin, H. H. The dieply of inforwation and the judgment of contingency. CanAdin Journil of Pyzholory, 1965, 19, 231241.

Hoods. D. H. Inproving estinates that Involve uncortalnty. Hervand Businegs Rovicw, 1966, 44. 91-98. 
COALS OF COST-BSKEFIT ANALYSIS IN EHECTRICAL POWER GEHERATION

by

Donald E. Watson, M.D. .

Bio-Medical Division, Iawren:e Livermore Laboratory

University of Californie, Livermore, Californis 94550

\section{INTRODUCTION}

The convening of this symposium Indicates that there is a significant degree of uncertainty about the expectations and goals or cost-benerit analysis, particularly as it relates to development of nuclear technoloce. It is hoped that cost-benefit analysis can be a velicle for including technological ractors in the public decision-making and policy-making processes. Recently, with the Calvert cliffs' declsion, the need for dependable, well-focused costbenefit assessment has been sharpenod considurably. This paper is an exanination of a few of the realist Ic expectations of cust-benefit analyais. Bather than being comprehensive, these parenthetical comments should be complementary with other papers to be presented.

I think it is 1rantc that cost-benefit analysis, under a variety of naves, is so casually acrepted in the "non-scientific" rields of politics, industry, and business, but is a source of ajor controversy and debute ang mang sclentists, even though they, by tradition, have preespted the Fleld or quantitative evaluation of phenomen and interactions. I believe the problen arlaes from the "subjective" variables wich ach be Included in cost-benerit andysis even tbough they are difflculi cr inpossible to quintsfy. Izt, in siny cases, if the unriables to be consitered are linited to those that can be accurately evaluated, the scope of the annlysis will be wich too isfted; costs, rishs and benerits cun be evalunted to am desired eccuracy, eccording to any irternuily coalstent mebod, and st11l be Irrelevant to the problen of the dy. For extaple, the risks of cureinopanests rros both

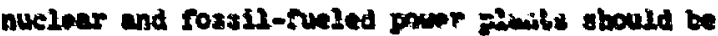

compared. Neither of these risks is intrinsically very high, but the degree of publle concern surrounding the Issues is so great, the evaluation problen itself is of exquisite importance. For this reason, an "objective" cost-beneflt anslysis would be virtunly uselass if it did not address the real, but subjestive, problem areas.

Beforc proceeding, I would like to make a distinction between "rosts" and "risks" to provide a frame of refarence for comparing them. Costs are effects which vary continuously with their driving forces -. in delation to sac lety or the individual. On the other hand, discrete phenomena, whlch are either banfested or not in individuals, have assoclated levels of risk; the value of the risk is defined as the probability of the phenomenon's occurrence.

Risks can be characterlzed as costs if the frame of reference is expanded from the individual to the soclety as a whole. In other words, the occurrence of discrete events can be approximated by a continuous function if the population is large. As an example of the "cost-valuation" scciety applies to such phenoment, cuncer is : onsidered to be worthy of a wab greater research investment than arctropbic laterw scleronis, an Imariably fatal -o but mach ruror - diaense. Accordingly, there is aple pratedent for considering conts and risks to be qualitatively equiralent if the frane of reference is lexger than the Individun. With this jutticication, t afor tak contronting cost-beserit enayste and decinion-mirers is to find an acceptble uditin or exchnes, or coman busts for quantitative eorparsea, for the two. 
THE "ART" OF COST-BENEFIT ANALYSIS

I have characterized the field of cost-benefit analysis as an "art" to indicate that its application will not always depend on accurate assessments of all of the variables to be considered. ${ }^{1}$ In the s.rt of medicine, for example, costly and/or risky treatment is characteristically prescribed on the basis of a "presumptive" diagnosis. Such a diagnosis depends upon many factors, of which only a few can be rigorously measured. To distinguish an "art" from a "science," an art is characterized as a fiela in which it is more important to be right thar to be rigorous. This designation emphasizes some of the features shared by the practice of cost-benefit analysis and that of the art of medicine.

In medicine, a recomendation for treatment is made if it is predicted that benefits will be derived which outweigh the risks and costs. The benefit the patient can expect is the overall reduction of the risk of mortality or morbidity, but this benefit will really exist only if the diagnosis is correct; it is inevitable that for some cases, the costs and risks of the treatment will be incurred with no actual beneflt at all. The art of medleine is prauticed acceptabiy, though, despite a significant degree of uncertainty surrounding specific applications to individuals. The acceptability results from the favorable incegrated benefit-cost balanca it offers the society as a whole, and also from the generally racognized fact that research designed to improve this balance is continuously in progress.

In the field of cost-benefit analysis, as in the field of mediciue, there are strong pressures to Froduce acceptable solutions for current problems. Decision-makers cannot always walt untii they bave all the facts. Consequently, hum judgment and intlition must be used to extend the relevance and applicability of iinited information ard meagex knowledge. Since society both provides the pressures for solutions, and establishes the levels of seceptability, this intuitive appmech w12: be wost prjductive if the sclentific ond tenhnologtcal insiltutions work together with our broad zociel and political todies. Furtberrore, these instititions wist use trial-and-error prubler:iolving methods, sc thay cannot realistinaly be expested to uniforisy provide perfect solutioas.

\section{RISK-ACCEPTABIHIHY EVAII WIOR}

Some very small rlaks are ext.remely inpcrtant simply because they are thought to be important. That phenomenon is real, even though it doesn"t "seem right." The roots of society's evaluntion of risk are found in the individual's ability to conprehend the meaning of risk, buc it is difficult for an individual to intuitively assign a "costvalue" to a risk of any given manitude. Bven though the "real," or intrinsic value or" a risk ay be Low, the individual ray actribute a moh higher extrinsic value to it. Becsuse $n$ the disparity between the intrinsic and extrinsic values of risks, risk evaluation and risk-acceptability eveluation are two distinct problems. Since costs are related to individual experiences, and risks are related to population experiences, it seems reasonable to look to the soclety as a whole for examples of "acceptable ${ }^{\pi}$ levels of riak for activities that have some asscciated level of benefit. This could be salled retrospective risk-acceptablizity evaluation.

A prospective riak-acceptability evaluation is much more difficult, obviously. This epproach ast be used, though, to estimate the extrinstc va'ue which is placed on a future riak, such as that from nuclear power plants. I anticipate that society's reactions to new, and therefore untested, risks are likely to be wantfested by high extrinsic values on the risks. Again, psychological characteristics of individuals are expected to determine the population response; in this cose, Intrinstcally low-level risks that are unfamiliar are likely to be given higher extrinsic vaiuntion tben equally low level risks that are familiar. Thus, "fear of the unknown" and " faniliarity bresis contengt" are reactions that wast be expecied.

It is hoped that benerit-rish andyals can be helpful in reconc:ling tixe afferences between intrinsic and extrinsic eveluutions. Fewehing this goal Itself, morever, is an independeat probles. To accouplish it, the level of fadilarity for the projected risk aloht be increased by an ubtract ecucation process, since intuition, procens of wental eneloss-referencling, Is necessury part of risk eviluntion, the public wifht be atsentrely informed by refersing to riale in alrowd namilar terins. Berbags, for this purpose, a ult of riak 
might be used that has a name such as "cig," which woul 3 be defined as the level of risk incurred by smoking a single cigarette.

\section{COST-BENEF IT CONSIDERATIONS FOK ELECTRICAL POWER SOURCES}

The predominant sources of electrical energy in the coming generation will be fossil fuel combustion and nuclear fission. Since the major binefits of electrical power generation are the same regardless of the ultimate source, comparison of cost-benefit cunsiderations of nuclear and fossil-fueled power plants reduces to a problem of cost comparisons alone. In fact, if there were only one source of energy, cost-benefit analysis would not even be necessary, since the benefits if electrical power production so far outweigh the costs of production, including envirormental costs.

Except for thermal release, which is about the same quantitatively for fossil-fueled and nuclear plants, the potential environmental effects or operation of these sources are not directly comparable. Most of the harmful effects of fossil fuel combustion are manifested as costs -- acute human heulth effects, and damage to materials, plants and ccunmercial crops. On the other hand, the expected radiation-related effects of nuclear plants are risks -- these would result from long-term low-close exposure to radionuclides. Stiil, there is a body of experimental evidence suggesting that combinations of air pollutants emitted from fossil fuel combustion processes, including electrical power production, are capable of producing and/or promoting cancer. ${ }^{2}$

It can be predicted that fossil-fuel pollution presents a significant risk of carcinogenesis to the general population. This quelitative prediction is based on two sets of observations; first, that benzo( $a$ )pyrene (BaP) is one of the most potent and most abundant of the carcinogens in cigarette smoke, and second, that the ambient air of American cities contains enough BaP to provide a dose rate to individuals equivalent to that of light amokers. It is not accurately known whether the magnitude of the risk is of the same order as that from radiationrelated environmental pollution due to nuclear power production. Nevertheless, the qualitative prediction carries with it a presumption that must not be ignored when comparing the relative environmental costis of nuclear and fossil-fuel power production.

A very rough approximation of the dose-risk relation for BaP alone can be made by referring to the smoking-cancer studies, by oversimplifying in places and by ignoring co-carcinogens altogether. This value, in turn, can be used to estimate the magnitude of the risk incurred by breathing polluted air. These csiculations depend on a few simplifying assumptions: (1) the lung cancer initiation rate among cigarette smokers increases linearly with the integrated EaP inhalation rate; (2) the co-carcinogens in cigarette smoke amplify the effectiveness of BaP by a factor of 40; that is, BaP alone accounts for only $1 / 40$ the total activity of cigarette smoke; (3) the effective duration of risk in the human population is 40 years; and (4) by averaging the male and female lung cancer initiation rates for the range of 1-19 cigarettes a day, a wide range of physical smoking parameters will be included.

A "bapman" is defined as a unit of exposure of one man to one microgram of BaP in one year. The annual rate of BaP exposure from smoking 10 cigarettes a day is about 60 micrograms. Using the assumptions above, and values of the annual excess risk of lung cancer for all ages of smokers, men and women taken together, ${ }^{3}$ it can be shown that the risk associated with one bapman exposure is $5 \times 10^{-6}$. In other words, $2 \times 10^{5}$ bapman of exposure would result in one death. It follows that the risk associated with the bapman unit is about an order of magnitude less than that for a man-rem.

The exposure to BaP from ambient air breathed by American urban populations can be calculated in bapman units by referring to data in the literature, 4 and by assuming a daily tidal volume of 30 cubic meters. For 10 cities, representing a total population of 17.2 million people, the exposures range from $2.6 \times 10^{7}$ bapman in New Orleans, to $4.9 \times 10^{8}$ bapman in New York. The calculated average projected death rate using the 10 city sample is about the same as for light smokers -- 48/100,000 population, on an annual basis. For a population of 100 million persons at risk, the predicted incidence of cancer resulting from BaP exposure is 48,000 . 'Assuming that electrical power generation accounts for only $1 \%$ of the total BaP in the atmosphere, the expected number of deaths due to fossil fuel power 
production is about $480 /$ year currently, from an exposure of $3 \times 10^{6}$ bapman. By comparison, this risk is larger by a couple of orders of magnitude than that expected to result from the 5 to $6 \times 10^{4}$ man-rem due to nuclear power production by the year 2000 .

\section{SIMMART}

Cost-benefit analysis is a pronising vehicle for promoting meaningrul commication between the technolngical and the fublic-poifey-making communities. However, the realization of this potential depends on the realistic assessment of the goals and limitations of cost-benefit analysis. Cost-benefit analysis is characterized as an "art" to indicate that it can be practiced imperfectly, but acceptably, in the absence of definitive information, while still investing in increased knowledge from research. Because of imperfect knowledge, and imperfec decision-making institutions, it is unrealistic to demand perfect answers from cost-benefit analysis. Nevertheless, in view of the pressure for acceptable solutions to current problems involving nuclear technology, it should be practiced despite the uncertainties.

Risk-acceptability evaluation is distinguished from risk evaluation, and is considered to be relevant to the overall goals of cost-benefit analysis. It is suggested that the public might over-react to proposed projects, despite small intrinsic risks, because there is no intuitive familiarity for phenomena which have not been experienced. It is proposed that the disparity between intrinsic and extrinsic risk values can be reconciled by positive attempts to infonm the public, with the goel of increasing the public's familiarity with risks.

As an example of the use of comparative risk evaluation, the risks of carcinogenesis from fossilfueled and nuclear power generatrion are compared. Despite considerable uncertainty in establishing the magnitude of the risks, it is shown that current levels of pollution from fossil-fueled power plants constitutes a risk that is probably considerably higher than that from projected nuclear power plents.

\section{ACKONOWLEDGMENT}

This work we.s supported by the U.S. Atomic Energy Commission.

\section{REFERENCES}

1. Watson, D. E., "Comparative Environmental Costs of Energy Sources; A Perspective," Proceedings of the Health Physics Society Sixth Annual Topical Bympostum, Rlchland, Washington, November 2-5, 1971. (In press -- preprinta avai? able.)

2. Watson, D. E., The Risk of Carcinogenesis from Long-tierm Low-dose Exposure to Pollution Emitted by Fossil-fueled power Plant's, University af California Lawrence IIvermore Laboratory Report UCRL-50937, October 1, 1970. (Reprlints ava11able.)

3. Hamond, R. C., "Smoking in Relation to thie Death Rates of One Million Men and Homen," in Epidemiolugical Approaches to the study of " Cancer and Other Chronic Diseases, National Cancer Institute Konograph 19, January 1966.

4. Preliminary Air Pollution survey of organid Carcinogens, National AIr Polluiton Control Administration Publication No, APMD 69-43, U.S. Dept. of Health, Education and Welfare. P.H.S. 1969. 


\section{ABSTRACT}

Nuclear operations cannot be Judged on a "safe or unsafe" basis, but rather on a "how safe" basts. The allowable degree of risk should be commensurate with the anticipated benefit from the operation. Benefit-risk aneiysis attempts to provide sound techniques for such determinations.

A phenomenon of recent times is the strong pubIic awareness and concern with regard to the environment. Today one can hardly plck up a newspaper or hear a newscast without learning of some major ecological disester which 18 about to befall us if we 3Te not vigilant. Student and citizen groups are organizing to fight pollution and save our environment from one menace or another. I sometimes wonder how mankind could have survived to this day without the enlightenment that is currently being provided us by the plethora of latter-day environmentalists surrounding us.

Unfortmately, much of this activity has resulted in confusing the public to the point where they do not know who or what to believe, and has also managed to stimulate or stampede, depending on your point of view, various governmental agencies into taking action. To Install a nuclear power reactor nowadays, it seems one must essentially provide an Ironclad guarantee that no adverse consequesces of any kind $c$ s degree will occur as a result.

Certainiy public awareness and concern over matters of pollution can go a long way toward preventing abuses of the environment. The problem comes in determination of fust what is abuse, and what is a reasonable and acceptable consequence of fndustrial development. It comes when emotionalism encers the picture, when those who apparently belleve. that no sacrifice is too great to achieve a prist' de enviriroment oppose any lndustrial plan whlch cotrles with it any degree of risk, no matter how slight. In a state of emotionalsim and rancor it is difficult to maintain any reasonable perspective. To resolve such problems we should first realize that no industrial operation or, Indeed, any endeavor of mankind, is entirely devold of risk. Therefore, fudgement shoula be made not on the basis of whether or not an operation 18 safe or unsafe, but rather on how safe. Having determined this, one is then confronted with another question: "How safe is safe enough?"

In recent years a few articles have appeared In the literature attempting to place radiation risks in perspective. The authors who have ventured to discuss the subject Include names such as Sowby, Barry, Otway, Lindell, Dunster, and Starr. Their efforts consisted, more or less, of preliminary attempts to quanify the risks of radiation exposure and other risks commonly accepted in everyday 11fe. In general, the methods and techniques for dotng this have been categorized under the heading of Benefit-Risk Analysis. Benefit-rlok analyols has is its objective, to deteraine a rational means of evaluating the potentlal benefits of any given operation, program, or technology against its posstble rlsks. To understand what benefit-risk analysis might accomplish, one may simply look at what happens if we don't use it.

For example, in evaluating the potential radiation effects of nuclear applications, an approach 
which has historically been taken is the use of the so-caj.led "worst case" or "maximum credible incident" concept. This involves a determination of the worst possitle chain of events and biological consequences which might occur as a result of the particular application considered. In my opinion, this approach has been abused. It of ten has made little difference tow bizarre or improbable the assumptions in such an analysis were, since one had only to show that some undesirable effect could occur at a probability le'rel greater than zero. Opponents of a proposed operation could destroy it simply by exercising thetr imaginations to cream up a set of conditions which, although they might admittedly be extremely tmprobable, could lead to some undesirable result. With such attitudes prevalent, planning a given nucleat operation becomes somewhat perflous since it requires predicting the extent to which the adversarles can employ their imagination.

To those basically opposed to nuclear development, any amount of risk is apparently unjustified. Such attitudes can be constdered unreasonable" for the simple reason that any Induatrial enterprise Involves some risk. One might reasonabiy ask why ruclear development should be singled out for special restriction. A far more rational approach might be to determine whether the risks are justifled by whatever benefit is to be antictpated.

To evaluate and compare beneftt versus risk, it is necessary to measure both in comparable units or to essentially determine a common denominator. In our soctety, money has Historically been the method of barter, and people are conditioned to think in monetary terms. Certainly, the value of money is better uncierstood by most people than anything else. For this reason we have advocated a system of evaluation of risk in monetary terms. For radiation exposure, as an example, we have estimated the value of $\$ 250$ worth of damage per manrad of exposure. Estimates by other authors have been consistent with this value, use of such a figure allows one to determine a measure of risk In monetary terms agafnst which one could compare the cost for avolding such risks.

Such an approach was stimulated by the observation that people's response to rtsk or potential threat of danger often bore little relattonshtp to the magnttude of the danger. Grosser, Weschler, and
Greeriblatt, in their book The Threat of Impending Disaster, * give illustrations of this point. For example, on one hand are show: examples of people ignoring hurricane warnings, deaptte the fact that once a warning has been issued in a given area, the probabllity of a hurrlcane strlking is quite high. On the other hand, threats involving lonizing radiation such as the siting of a reactor nearby, can bring a strenuous overreaction out of all proportIon to the seriousness of the threat.

People's reactions to threat of danger is of ten a function of their earlier conditioning. GIven the knowledge that the nuclear age was begun in wartime, it is understandable that vistons of H1 roshtma can eastiy be confured up whenever nuclear applications are considered, at least In the mind of the general public.

By placing risks and benefits on a common scale of measurements, we might hopefully. guide public constderation to a more rational and obfective basis of understanding.

A summary of the points I have attempted to make follows:

1. No Industrdiul operation, be tt nuclear or conventional; 18 devold of risk, Inded, nowendeavor of mankind can make such a clatm.

2. This being the case, one showd not speak of operations in terms of "safe" or "insafel, but rather "how safe" Quantitative evaluations of risk should be essential.

3. Acceptance oñ any of operton gram should be based on a quant t tat fve comperison of these risk evaluat lons to beneffts to be derived from their application. Should the $\mathrm{rloks}$ out welgh the benefit , the operatton ohould, of gourse, be rejected. The anount of effort expended to deter mining potent lal benefi 1 ohould be col enourate with that involved in determining the righo.

4. These evaluat 1ons ahould be exphes od do

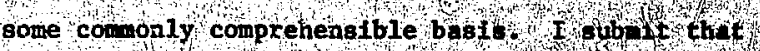
n monetary values best serve as such o bollo

Publlshers. The M.I.T. Press, Gaubridge, Massachusetts.

* Work pepformed under the auspices of the U.S. Atomic Energy Commission. 
Appendix I

Names and Addresses of Attendees

Dr. R. Lee Aamodt

Univer aity of California

Los Alamos Scientific Laboratory

P. O. Box 1663

Los Alamos, New Mesico 87544

Dr. Howard Arnold

Manager, Engineering

Pressurized Water Reactor Division

Westinghouse

Box 355

Pittaburgh, Pennsylvania 15230

Mr. Rol art Catlis:

U.S. Atomic Energy Commisaion

Washington, D. C. 20545

Mr. Paul Clifton, Coordinator

Resources Agency

State of California

1416 - . 9th Street

Sacramento, California 95814

Mr. Joseph Coates, Program Manager

Exploratory Resear ch and Problem Assessment

Research Applications

National Science Foundation

Washington, D.C. 20550

Mr. Jerry J. Cohen

University of California

Lawrence Livermore Laburatory

P.O. Box 808

Livermose California 94550

Dr. Joseth DiNunno

U.S. Atomic Energy Commitsion

Washington, D.C. 20545

Mr. Fritz Draeger, Coordinator

Nuclear Information Program

Pacific Gas and Electric, Rm. 1713

77 Beale Street

San Francisco, California 94106
Mr. Ha: \&y Ettinger

University of California

Los Alamó Scientific Laboratory

P. O. Box 1663

Los Alamos, New Mexico 87544

Dr. Donald Geesaman

Univ'srsity of California

Lawrence Livermore Laboratory

P. O. Box 808

Idvermore, California 94550

Mr. Don C. Gilbert

Atrizona Atomic Energy Commiseion

Fivet Floor Commerce Building

1601 Weat Jefferson Street

Phisenix, Arizona 85007

Dr. Oswald Greager, Chairman

Thermal Power: Flant Stte Evaluation Council

820 East Fifth Avenue

Olympia, Waskington 98501

Dr. David Hall

Univer sity of California

Los Alamos Scientific Laboratory

P. O. Box 1663

Los Alamos, New Mexico

87544

Mr. Robert Hammon

EG\& G

2801 Old Crow Canyon Road

San Ramon, California 94583

Mi. Joel W. Hedgepeth

Marine Science Center

Nenport, Oregon 97365

Dr. Gary Higgins

Univer sity of California

Lawrence Livermore Laboratory

P.O. Box 808

Livermore, Caltifornia $\mathbf{9 4 5 5 0}$

Mr. Oscar Lee

Public Service Company of Colorado

550 - 15th Street

Denver, Colorado 80202 
Dr. Ronald X, Lohrding

Univer sity of California

Los Alamos Scientific Laboratory

P.O. Box 1663

Los 4lanies, New Miexico 87544

Mir. Dan McNellis

Fublic Service Company of Colorado

550 - 15th Street

Denver, Colorado 80202

Dr. F. Peter Metzger

Colorado Committee for Envircamental Information

2595 Stanford Avenue

Boulder, Colorado 80303

Mr. Jack Moore, Vice-President Southern California Edison Co. P.O. Box 800

Rosemead, California 91770

Mr. W. I. Oakley

U.S. Atomic Energy Conmission

Washing. on, D. C. 20545

Dr. William E. Ogle

University of California

Los Alamos Scientific Laboratory

P. O. Box 1663

Los Alamos, New Mexico 87544

Dr. Harry J. Otway

Univer sity of California

Los Alamos Scientific Laboratnry

P.O. Box 1663

Los Alamos, New Mexico 87544

Mr. Gerald Rausa

103 Daleview

Timonium, Maryland

Mr. Anthony Ripley

c/o The New York Times

430 - 16th Street

Denver, Colorado 80202

Mr. Keith Roberts

3400 Dwight Way

Berkeley, California 94704

or

Suite 205

228 McAllister Street

San Francisco, California 94102

Mr. Wyatt M. Rogers, Jr.

Weatern inter state Nuclear Board P. O. Box 15509

Lakewood, Colorado 80215
Dr. Marc Ross

Department of Physics

University of Michigan

Ans Arbor, Michigan.

48104

Mr. Romano Salvatori

Manager, Iicensing and Engineering

Westinghouse

Atomic Power Division

Nuclear Systems Division

Pittsburgh, Pennsylvania

Ms. Dixie Lee Savio

Western inter state Nuclear Board

P. O. Box 1550 9

Lakewosd, Colorado 80215

Mir. John G. Sinclair, Jr.

Sinclair Research

Airport Road

Little River, California 95456

Dr. Paul Slovic

Oregon Rescarch Institute

P. O. Box 3196

Eugens, Oregon 97403

Dr. Chauncey Starr

Dean, Engincering and Applied Science

Univer sity off California

Los Angeles, California 90024

Mr. Tom Ten Eyck, Director

Coloraco Department of Natural Resources

1845 Sherman Street

Denver, Colorado 80203

Mr. Wallase R. Utley

Arizona Public Service Company

501 South 3rd

Phoenix, Arizona 85030

Dr. B, H. Van Domelen

Governor's Science Advisor

Sandia Laboratory - 2345

Albuquerque, New Mexico 87115

Mr. Lym R. Wallis

General Electric $C_{0}$.

175 Curtiner Ave.

San Jobe, California 95125

Donald E. Wation, M, D.

Univer sity of Galifornia

Lawrence Livermore Laboratony

P. 0 . Box 808

Livermoro, California 94550 
I Jenn Warth

ciáte Director for Plowshare

i. "rence Livejmore Labnrato:y

P.O. Box 808

Livermore, California 94550

Dr. Alfred T. Whatley

Executive Director

Western interstace Nuclear Board P. O. Box 15509

Lakewood, Colorado 80215
Dr. Mithael D. Williams

3710 Gold Street

Los Alamo8, New Mexico

87544

Dr. Albert E. Wilson

Department of Eisgineering

Idahn State Iniversity

Pocatello, Idaho 93201

Assemblyman Frank Young

P.O. Box 15090

Las Vegas, Nevada 89114 
Appendix II

Re suits cif Attendre. Survey

In order to assess the success of this Symposium tho se attending were given a questionnaire asking for numerical evaluation of several factors. Respondants were asked to rate these items on a scale of zero (very negative) to five (very positive). Space was also available on the form for other comments; anonynimity was provided in hopes of eliciting frank refiies. On the zero to five scale, a rating of 2.5 would indicate that the meeting met the persons's expectations on a particular point. Scores below or above 2,5 would indicate that ex. pectations were, respectively, not met or exceedf.d.

1. Do you feel that the time anci effort you put into attending this meeting were well spert?

$\begin{array}{ccc}\begin{array}{cc}\text { Score } \\ 0\end{array} & \frac{\text { Response }}{2} \\ 1 & 2 \\ 2 & 3 & \text { Average }=3.5 \\ 3 & 11 \\ 4 & 11 \\ 5 & 11\end{array}$

2. Do you feel that a similar meeting on other subjects (radioactive waste disposal, plant siting, etc.) would be worth while?

$\begin{array}{ccc}\text { Score } & \frac{\text { Response }}{0} & 3 \\ 1 & 0 & \\ 2 & 2 & \text { Average }=3.4 \\ 3 & 15 & \\ 4 & 10 & \\ 5 & 8 & \end{array}$

3. Was the mix of attenters reasonable?

$\begin{array}{ccc}\text { Score } & \text { Response } & \\ 0 & 1 & \\ 1 & 3 & \text { Average }=3.3 \\ 2 & 6 & \\ 3 & 7 & \\ 4 & 20 & \\ 5 & 4 & \end{array}$

4. Did the fnrmat used few talkexa, open discusaion) seem affective?

$\begin{array}{ccc}\text { Score } & \text { Resporge } & 1 \\ 0 & 2 & \text { Average }=37 \\ 1 & 3 & \\ 2 & 6 & \\ 3 & 15 & \\ 4 & 12 & \end{array}$

5. Were the speakers and topics selected worthwhile?

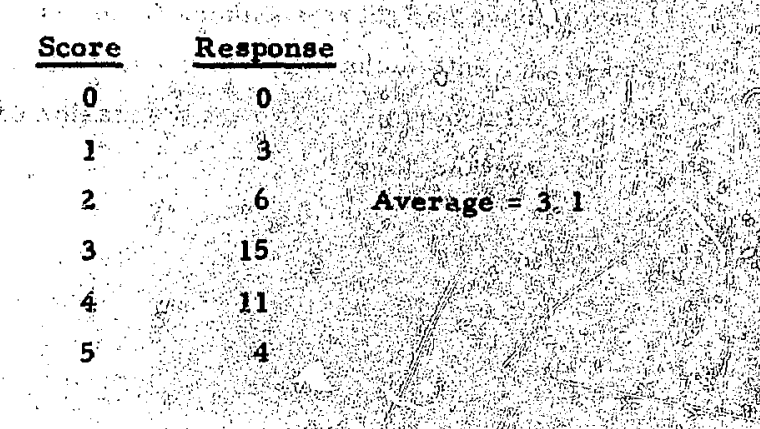

Some typical comm int follow:

"More critica reeded - power people keptso quiet it had to be a plamed thing, therefore the 
cannot be considered to have been participants, only wary observers. This is really remarkable when you think about it, since, nominally at least, they have the greatest Immediate stake in the outcome of this symposium."

"Not enough participation from Industry representatives. Is there some way this could be changed?"

"Need emphasis on techniques -- how-to drill and then on limits, what else needs to be done."

"There was not enough discussion on the method of Risk-Benefit Analysis."

"Meeting on me:hodo of risk benefit might be worthwhile."

"With one excoption, the opeakers talked about familiar material at a very rudimentary level. Many speaker s trok the opportunity to knock other participarts' positiono in a manner is relovant to the meeting. Without an opportunity to delve further into the iasues they added nothing to the meeting."

"Good start on a difficult problem -- next should be a marshalling of experte in the pertinent disciplines to kick off laying the foundatians for a test study."

"Should have had more speakers from anti-energy, anti-AEC, anti-technology, to present alternatives to present programe. No real difcasaion of benefit cost methodology."

\section{$\mathrm{HN} / \mathrm{st:} 832(500)$}

60
"The interface of multidisciplinary persons with the obvious difference of interests is the real cr:teria of success in this type of meeting: i.e. -even though we may still differ in our beliefs, at least this typu of face to face exchange opens the door to understanding why someone does not agree with you. Further, these meetings also provide another key necessary to successful arbitration -introduction to the opponent."

"Slimulating, well-organized. Particularly appreciated the exposure of critical views like Metzger's."

"It was interesting, but not really helpful -. everyone wen: out the same door they came in ...."

"Probably future meetings need better definition of topic and educational talks at the beginning."

"Chairman did a very good job of running the show. Since he is the key, suggest you make sure any cther meeting has a good man."

"Informal bull-sessions were most valuable to me. Good mix of people to talk with."

"Iuch benefit from informal sessions."

"Too much emphasis in the discussions on the philosophy and not enough on the specifics and the techniques that might $b=$ useful. I found the best interchanges took place autaide the formal seasions: " 


\section{APPENDIX III}

\section{Miscellaneous Phosographs Taken During Seadion}
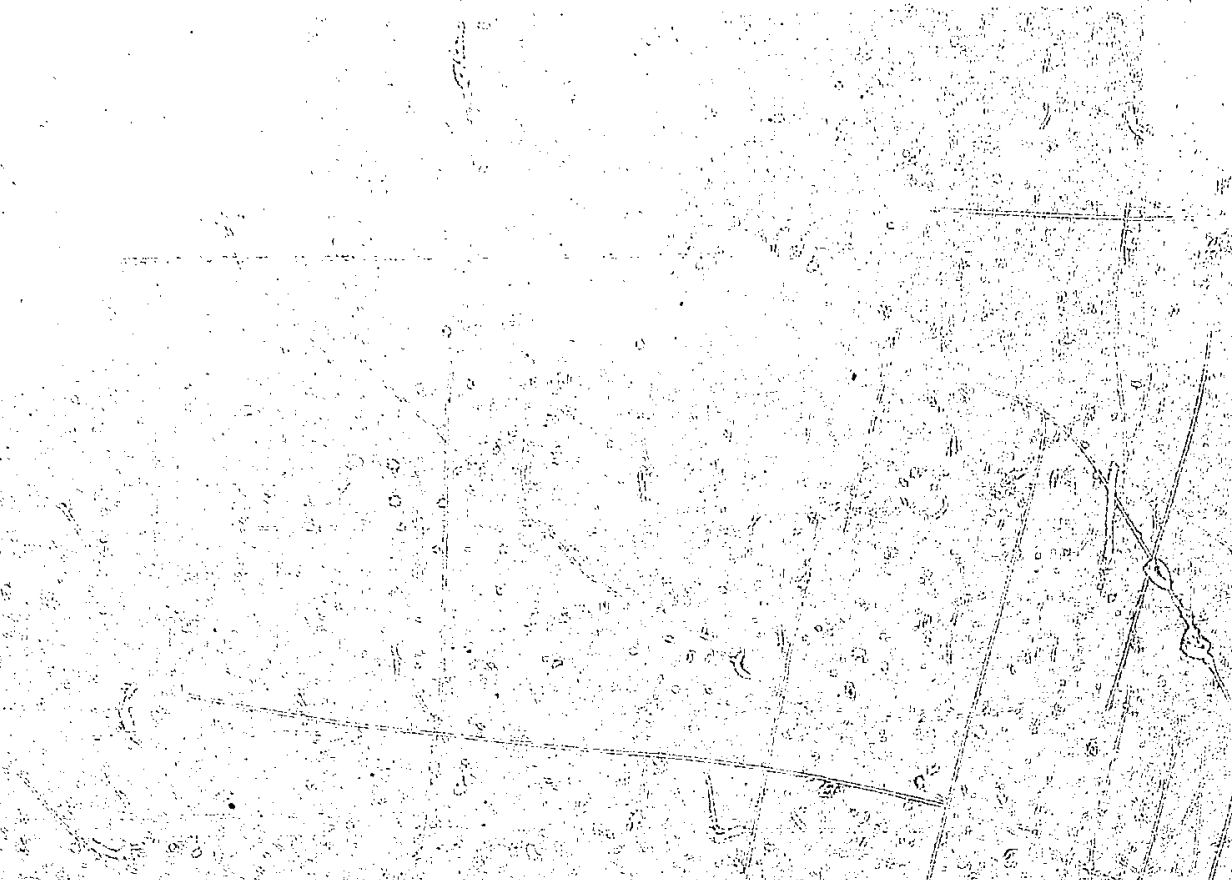

की 

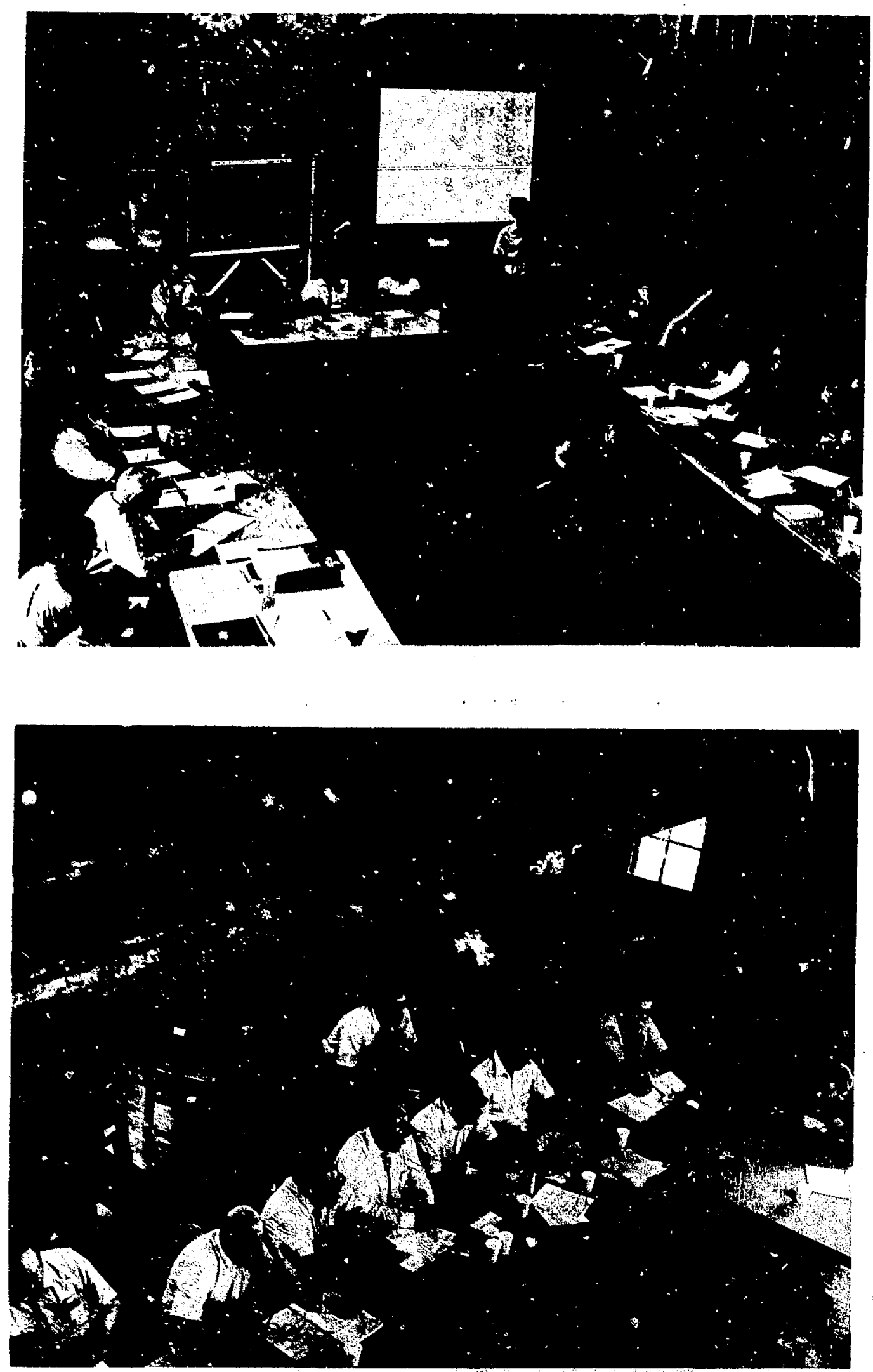

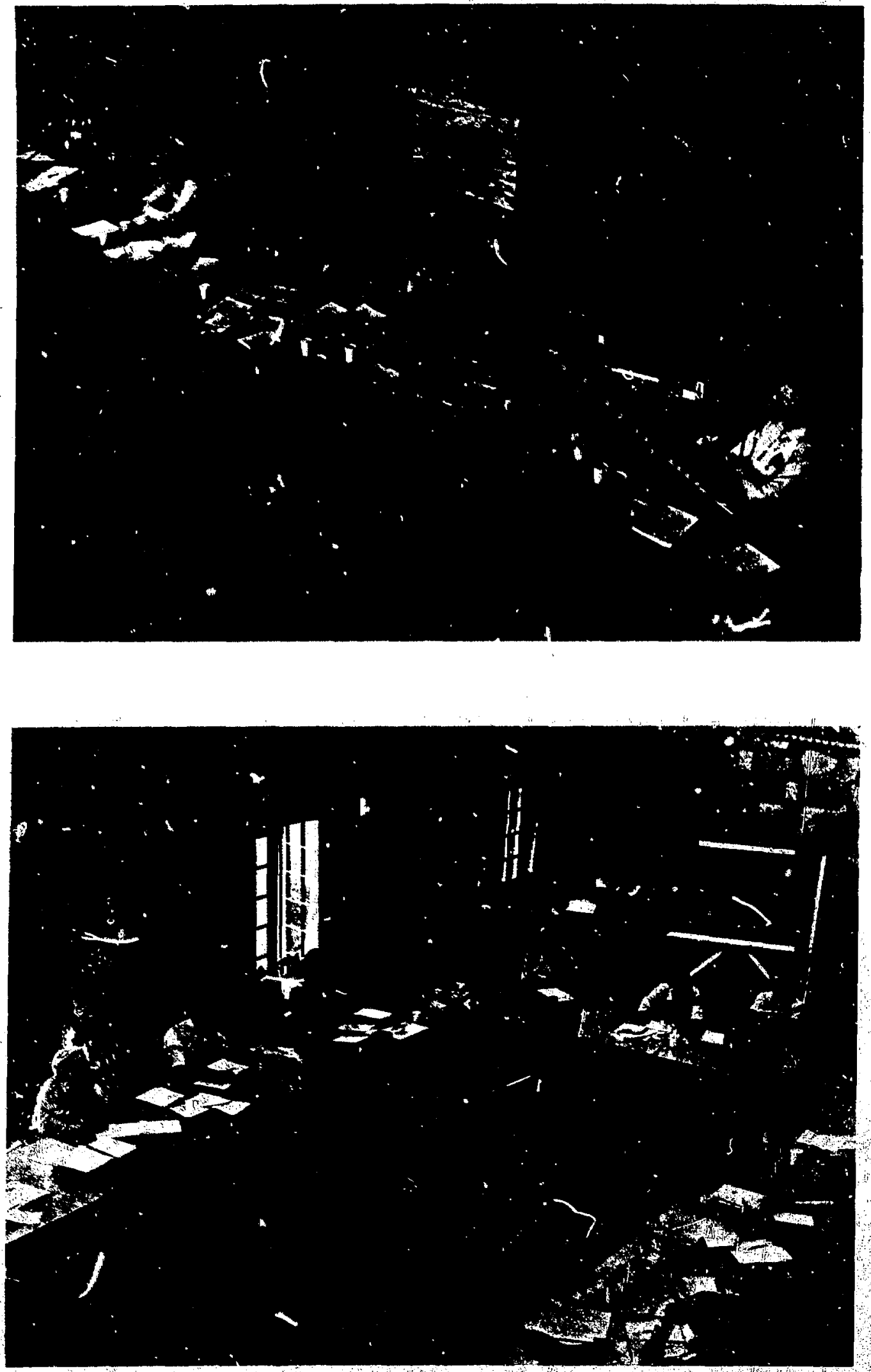

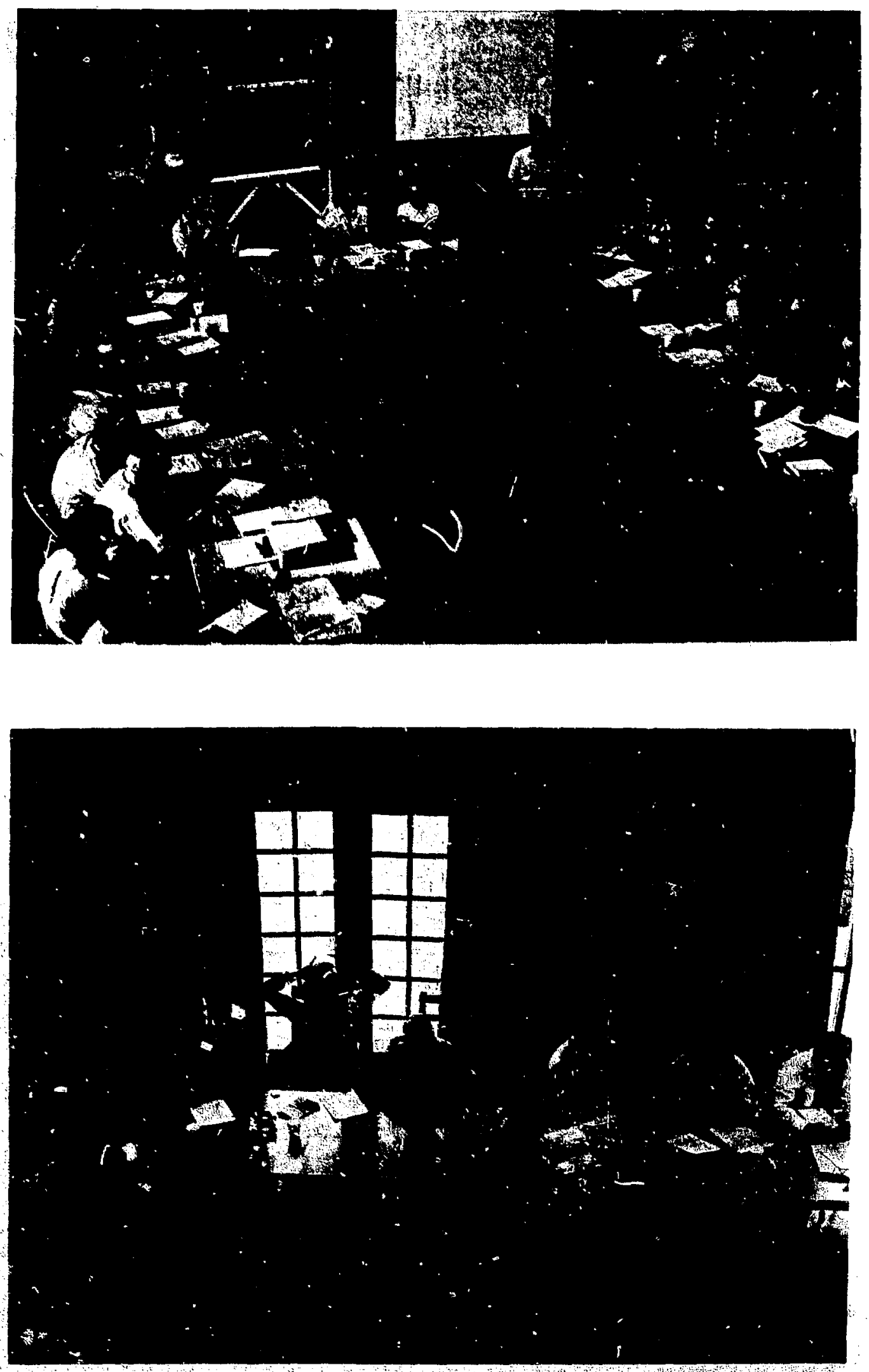


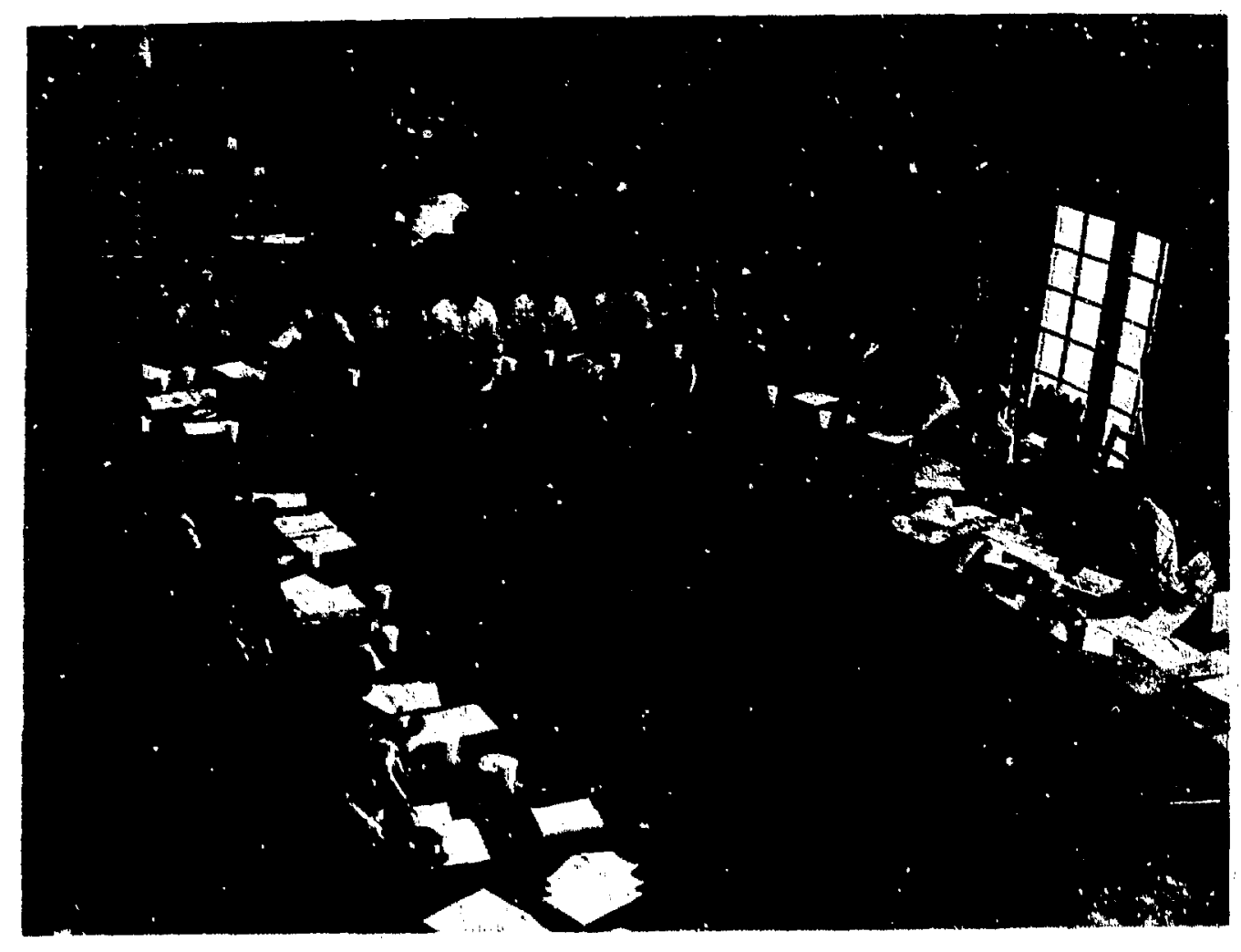

